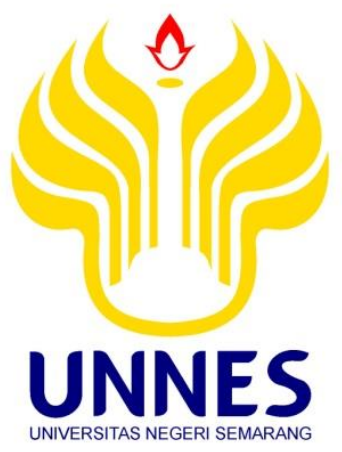

\title{
TEKNIK VOKAL DAN PERAN PEMANDU NYANYIAN JEMAAT DI GEREJA KRISTEN JAWA NGESREP KOTA SEMARANG
}

\section{Skripsi}

Untuk memperoleh gelar Sarjana Pendidikan 


\section{PERSETUJUAN PEMBIMBING}

Skripsi dengan judul "Bentuk Penyajian Vokal dan Peran Pemandu Nyanyian Jemaat di GKJ Ngesrep Kota Semarang”

Nama : Bella Monica Paula

NIM $\quad: 2501413147$

Program Studi $\quad$ : Pendidikan Seni Musik

Telah disetujui pembimbing untuk diajukan ke Panitia Ujian Skripsi.

Semarang, Januari 2018

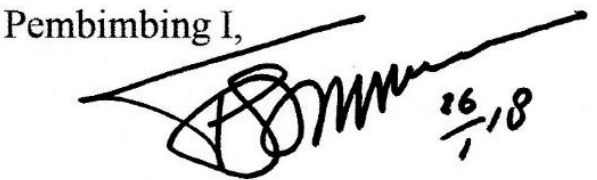

Prof. Dr.Totok Sumaryanto F, M. Pd

NIP. 196410271991021001

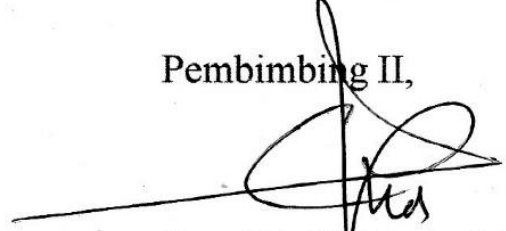

Drs. EkoR hario M.Hum

NIP. 196510181992031001

Mengetahui,

Ketua Jurusan Sendratasik

Dr. Udi Utomo, M.Si.

NIP. 196708311993011001 


\section{PENGESAHAN KELULUSAN}

Skripsi ini telah dipertahankan di hadapan sidang Panitia Ujian Skripsi Jurusan Sendratasik, Fakultas Bahasa dan Seni, Universitas Negeri Semarang.

$$
\begin{array}{ll}
\text { Pada } & \text { : Senin } \\
\text { Tanggal } & : 19 \text { Februari } 2018 \\
\text { Panitia Ujian } & \text { Skripsi }
\end{array}
$$

Prof. Dr. Agus Nuryatin, M.Hum., (196008031989011001)

Ketua

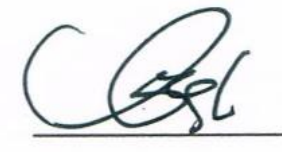

Abdul Rachman, S.Pd. M.Pd., (198001202006041002)

Sekertaris

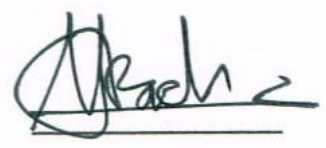

Drs. Moh. Muttaqin, M.Hum., (196504251992031001)

Penguji I

Drs. Eko Raharjo, M.Hum., (196510181992031001)

Penguji II/Pembmbing II

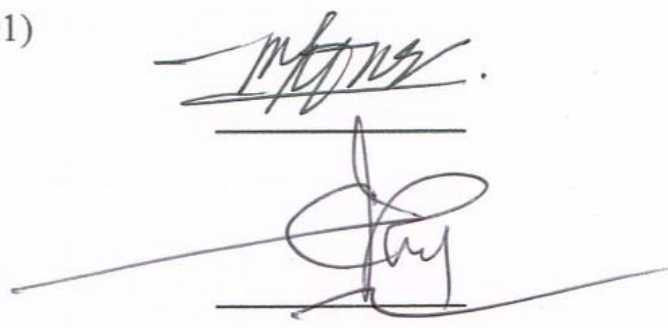

Prof. Dr. Totok Sumaryanto F, M.Pd., (196410271991021001)

Penguji III/Pembimbing I
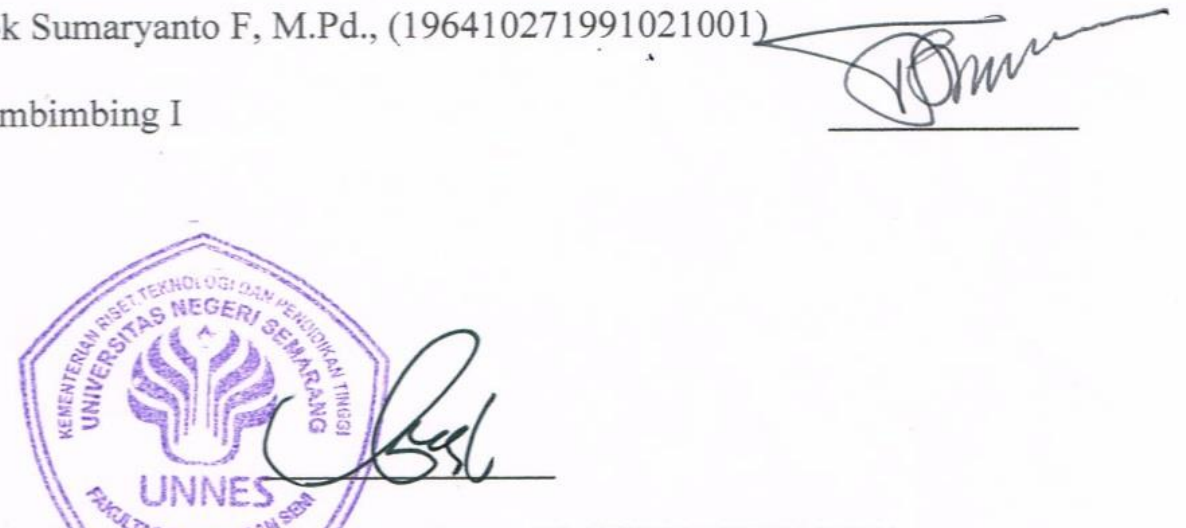

Prof. Dr. Agus Nuryatin, M. Hum., (196008031989011001)

Dekan Fakultas Bahasa dan Seni 


\section{PERNYATAAN KEASLIAN}

Dengan ini saya menyatakan bahwa yang tertulis dalam Skripsi ini benarbenar karya sendiri, bukan jiplakan dari karya tulis orang lain atau pengutipan dengan cara-cara yang tidak sesuai dengan etika keilmuan yang berlaku, baik sebagian atau seluruhnya. Pendapat atau temuan orang lain yang terdapat dalam tesis ini dikutip atau dirujuk berdasarkan kode etik ilmiah. Atas pernyataan ini saya siap menanggung resiko atau sanksi yang dijatuhkan apabila ditemukan adanya pelanggaran terhadap etika keilmuan dalam karya ini.

Semarang, Januari 2018

Yang membuat peryataan,

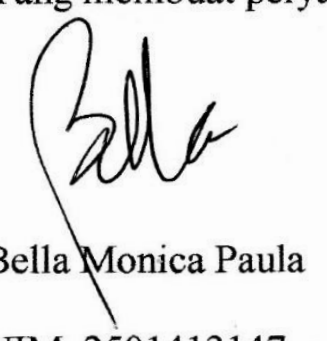

NIM. 2501413147 


\section{MOTTO}

1. "Nyanyikanlah nyanyian baru bagi TUHAN, menyanyilah bagi TUHAN, hai segenap bumi! Menyanyilah bagi TUHAN, pujilah nama-Nya, kabarkanlah keslamatan yang daripada-Nya dari hari ke hari” (Mazmur 96:1-2)

2. "Kerjasama dan teknik dalam bermusik merupakan kunci dari suatu harmoni dalam bernyanyi "

(Bella Monica Paula)

Persembahan :

1. Pendidikan Sendratasik S1 Unnes

2. Prodi Pendidikan seni 


\begin{abstract}
ABSTRAK
Paula Monica Bella. 2018.'Teknik Vokal dan Peran Pemandu Nyanyian Jemaat di GKJ Ngesrep Kota Semarang”. Skripsi Jurusan Sendratasik program studi pendidikan seni Musik S1. Fakultas Bahasa dan Seni. Universitas Negeri Semarang. Pembimbing 1. Prof. Dr.Totok Sumaryanto F, M.Pd. Pembimbing 2 Drs. Eko Raharjo, M.Hum
\end{abstract}

Kata kunci :Teknik Vokal, Peran Pemandu Nyanyian Jemaat,.

Nyanyian jemaat merupakan bagian dari musik gereja yang menjadi satu dengan liturgi, artinya setiap unsur dalam liturgi itu terangkai satu dengan yang lainnya membentuk satu kesatuan pemahaman iman yang diyakini umat, yaitu keyakinan akan keselamatan anugerah Allah atas manusia (Tim Sinode GKJ, tanpa tahun: 7). Pemusik dan PNJ merupakan bagian dari liturgi dan berperan sebagai sarana yang bertujuan membuat suasana menjadi hikmat sehingga mampu membawa umat pada tahap perjumpaan dengan Allah. Adapun permaslahan yang peneliti angkat, (1) Bagaimanakah teknik vokal dalam nyanyian peribadatan di GKJ Ngesrep, (2) Bagaimanakah peran pemandu nyanyian jemaat pada proses peribadatan di GKJ Ngesrep.

Penelitian ini mengunakan pendekatan metode penelitian kualitatif. Adapun lokasi penelitian ini dilakukan di Gereja Kristen Jawa (GKJ) Ngesrep, Jawa Tengah, teknik pengumpulan data dilakukan dengan cara observasi, wawancara, dan studi dokumen. Teknik analisi data yang digunakan adalah teknik analisi data sistematik atau interaktif

Hasil pembahasan, (1) Mengenai teknik vokal dapat diketahui bahwa teknik vokal dalam pemandu nyanyian jemaat (PNJ) yang terdiri dari 3 orang penyanyi dengan teknik vokal yang berbeda-beda yang memiliki kelebihan dan kelemahan masing-masing antaralain pada penyanyi yang pertama memiliki teknik pernafasan yang kurang baik akan tetapi suara pada saat bernyanyi lantang dan artikulasinya jelas, kemudian pada penyanyi yang ke 2 dan tiga memiliki kelemahan yang sama yaitu pada teknik suaranya yang kurang lantang, hal tersebut yang mengakibatkan terjadinya harmonisasi yang kurang baik pada saat bernyanyi dalam peribadatan di GKJ Ngesrep. (2) Berdasarkan pembahasan yang kedua yaitu mengenai peran pemandu nyanyian jemaat pada proses peribadatan di GKJ Ngesrep, bahwasanya seorang procantor yang memiliki tugas sebagai ketua pemimpin dalam nyanyian peribadatan. Adapaun tugas cantoria khusunya di GKJ ngeserep berjumlah 2 orang, dimana didalam bertugas cantoria menjadi pendamping procantor saat bertugas, akan tetapi didalam GKJ Ngesrep cantoria yang bertugas masih belum maksimal dan masih mengandalkan procantor dikarnakan yang bertugas menjadi cantoria belum begitu sepenuhnya menguasai tugas yang harus dilakukan salah satunya meteri musik dalam nyanyian peribadatan. 


\section{PRAKATA}

Segala puji dan syukur, dan kemuliaan hanya bagi nama tuhan, karna kebaikan dan kemurahan-Nya sajalah, penelitian dapat menyelesaikan Skripsi yang berjudul "Teknik Vokal dan Peran Pemandu Nyanyian Jemaat di GKJ Ngesrep Kota Semarang”. Skripsi ini di susun sebagai salah satu persyaratan untuk maju ujian Skripsi.

Peneliti ini dapat diselesaikan berkat bantuan dari berbagai pihak. Oleh karena itu, peneliti menyampaikan ucapan terima kasih dan penghargaan setinggitingginya kepada pihak-pihak yang telah membantu penyelesaian penelitian ini. Ucapan terima kasih peneliti sampaikan pertama kali kepada. Prof. Dr.Totok Sumaryanto F, M.Pd., selaku pembimbing utama dan. Drs.Eko Raharjo, M. Hum., selaku pembimbing kedua, yang selalu mengarahkan penelitian ini sehingga tersusunlah Skripsi dengan lancar dan terselesaikan tepat waktu.

Ucapan terima kasih peneliti sampaikan juga kepada semua pihak yang telah membantu selama proses penyelesaian studi, di antaranya:

1. Prof. Dr. Fathur Rokhman, M. Hum., Rektor Universitas Negeri Semarang yang telah memberikan kesempatan untuk menyelesaikan studi S1 pendidikan seni Sendratasik.

2. Prof. Dr.Agus Nuryatim, M.Hum, Dekan Fakultas Bahasa dan Seni Unnes yang telah memberikan izin untuk mengadakan penelitian.

3. Bapak Prof. Dr.Totok Sumaryanto F, M.Pd. dan. Drs.Eko Raharjo, M. Hum, pembimbing yang telah membimbing dan meluangakan waktu 
hingga Skripsi ini bisa berjalan dengan baik dari awal sampai akhir penyelesaian Skripsi.

4. Bapak Dr. Udi Utomo, M.Si., ketua jurusan sendratsik yang telah membantu dalam penyelesaian skripsi ini.

5. Bapak dan Ibu dosen prodi pendidikan sendratasik S1, yang telah banyak memberikan bimbingan dan ilmu kepada penulis selama menempuh pendidikan.

6. Bapak Pendeta, Bapak/Ibu Majelis, dan seluruh Jemaat Gereja Kristen Jawa Ngesrep Kota Semarang yang telah meluangkan waktunya dengan pintu terbuka pada proses penelitian, sehingga tersusunlah Skripsi ini.

7. Kecamatan Banyumanik dan GKJ Ngesrep, yang telah membantu dengan mengizinkan peneliti untuk melakukan penelitian dengan objek bentuk penyajian musik vokal dan peran pemandu nyanyian jemaat.

8. Teman-teman mahasiswa Program Studi pendidikan sendratasik khusunya Seni Musik UNNES angkatan 2013. Sebagai teman berbagi rasa dalam suka maupun duka, serta atas segala bantuan dan kerjasamanya sejak mengikuti studi sampai penyelesaian penelitian dan penulisan Skripsi ini.

9. Bapak (Paulus Purnomo) dan ibu (Amoepoeni) tercinta dan terkasih, yang tidak ada henti-hentinya sedari dulu memberikan semangat, dukungan, doa, kasih sayang, dan kekuatan yang begitu besar..

10. Adikku Bondan Satria Paulus yang tersayang telah mendukung dan mendoakan yang tiada henti 
11. Teman terkasih Dedy Firduansyah yang selalu membantu, mendampingi dan menginspirasi sehingga terselesaikannya Skripsi ini.

12. Teman seperjuangan dan sahabat Rani, Ecak, Yuke, Wita, Doni, Riky dan teman-teman satu angkatan 2013 yang selalu ceria dan baik hati.

13. Semua pihak yang tidak dapat peneliti sebut satu-persatu yang telah membantu dalam penyusunan Skripsi ini.

Semoga hasil penelitian ini bermanfaat dan merupakan kontribusi bagi pengembangan ilmu pengetahuan.

Semarang, Januari 2018

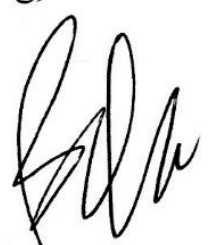

(Bella Monica Paula) 


\section{DAFTAR ISI}

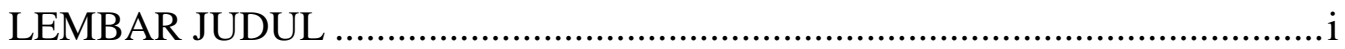

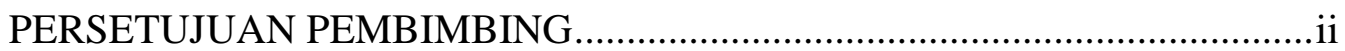

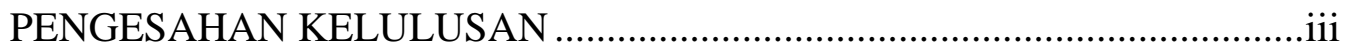

PERNYATAAN KEASLIAN .........................................................................iv

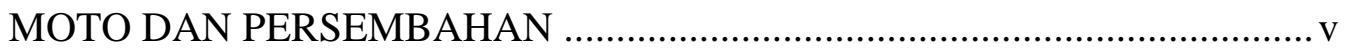

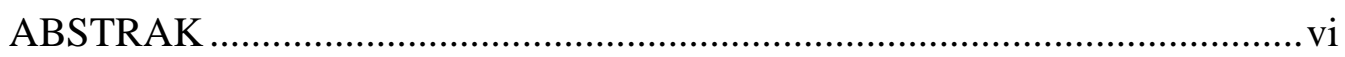

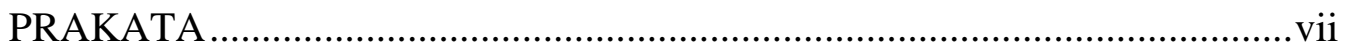

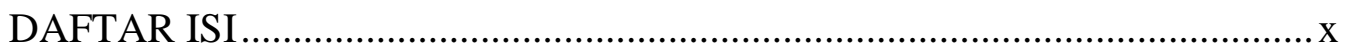

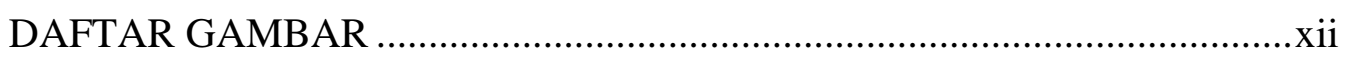

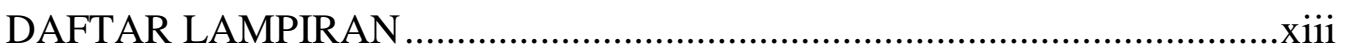

\section{BAB 1 PENDAHULUAN}

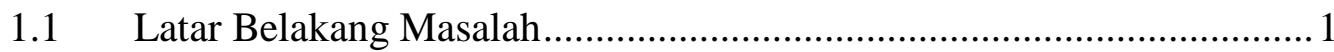

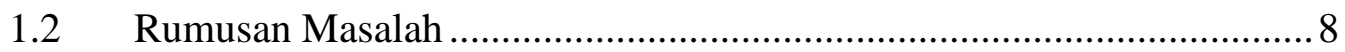

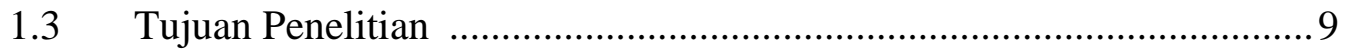

1.4 Manfaat Penelitian ....................................................................... 9

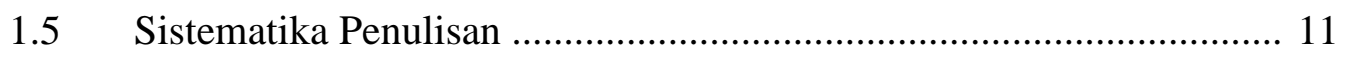

\section{BAB II KAJIAN PUSTAKA DAN LANDASAN TEORI}

2.1. Kajian Pustaka................................................................................... 12

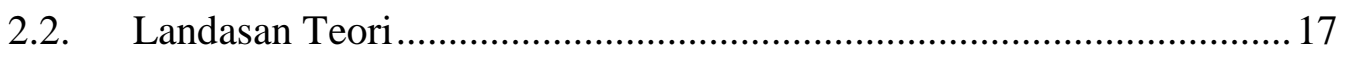

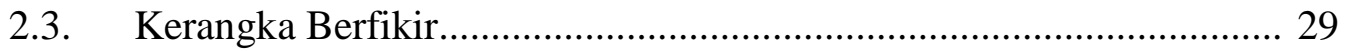

\section{BAB III METODE PENELITIAN}

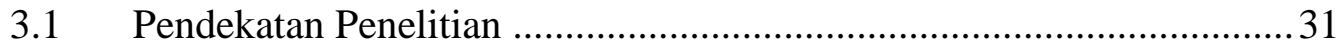

3.2 Lokasi dan Sasaran Penelitian .............................................................. 32

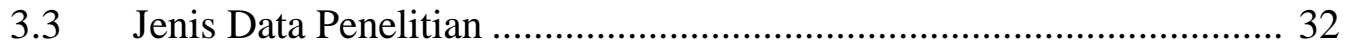

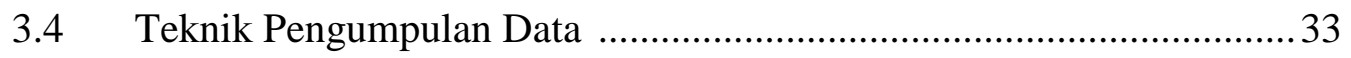

3.5 Teknik Penentuan Keabsahan Data .................................................. 35

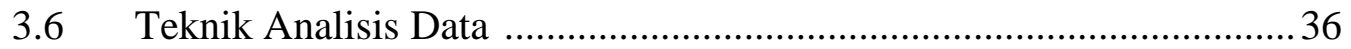

\section{BAB IV HASIL PENELITIAN DAN PEMBAHASAN}

4.1 Gambaran Umum Lokasi Penelitian ....................................................... 38

4.2 Teknik Vokal GKJ Ngesrep .............................................................. 53

$4.3 \quad$ Peran PNJ GKJ Ngesrep ........................................................... 70 
BAB V KESIMPULAN DAN SARAN

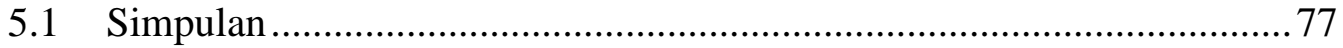

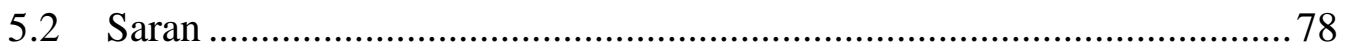

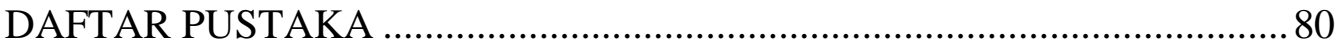

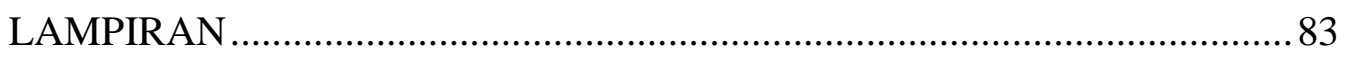

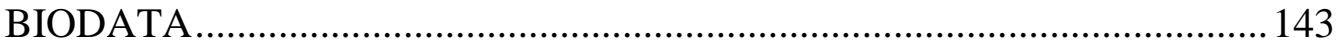




\section{DAFTAR GAMBAR}

Gambar 1. Bentuk Mulut Vokal A dan Posisi Lidah Vokal A...............................20

Gambar 2. Bentuk Mulut Vokal E dan Posisi Lidah Vokal E .............................21

Gambar 3. Bentuk Mulut Vokal I dan Posisi Lidah Vokal I...............................22

Gambar 4. Bentuk Mulut Vokal O dan Posisi Lidah Vokal O.............................22

Gambar 5. Bentuk Mulut Vokal U dan Posisi Lidah Vokal U.............................23

Gambar 6. Diagram Luas Wilayah Kecamatan di Kota Semarang .......................39

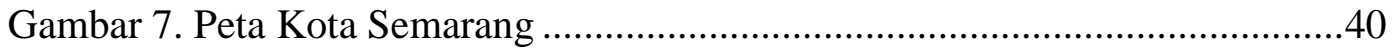

Gambar 8. Letak Gereja Kristen Jawa Ngesrep Semarang Pada Peta ...................42

Gambar 9.Gambar Gereja Nampak Depan .....................................................45

Gambar 10. Para Petugas Sebelum Memulai Peribadatan ....................................48

Gambar 11. Pendeta Memipin Doa Pembuka Kepada Para Jemaat......................50

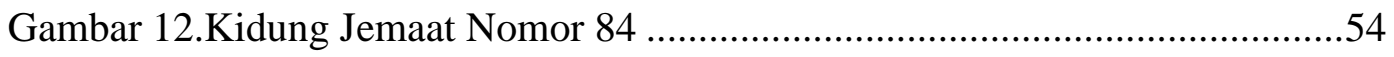

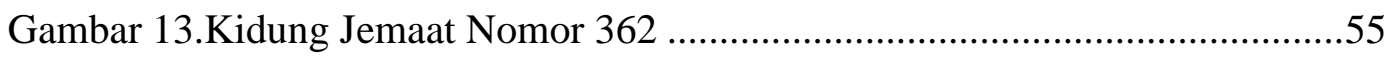

Gambar 14.PNJ Sedang Berlatih untuk Tugas Ibadah......................................59

Gambar 15.PNJ Sedang Bertugas Dalam Ibadah.............................................63

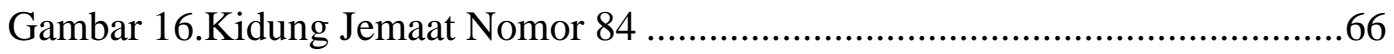

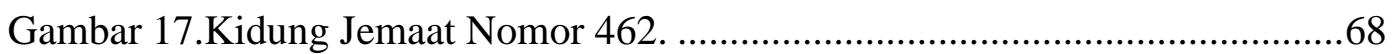

Gambar 18.PNJ Ekspresi Sedih Saat Bertugas Menyanyikan Lagu Penyesalan...68

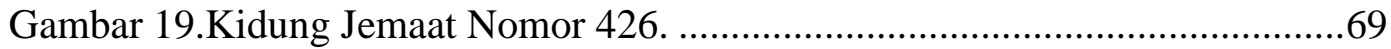

Gambar 20.PNJ Ekspresi Gembira Lagu Riang Menyambut Tuhan. ....................70

Gambar 21.PNJ yang Bertugas Menjadi Cantoria............................................75 


\section{DAFTAR LAMPIRAN}

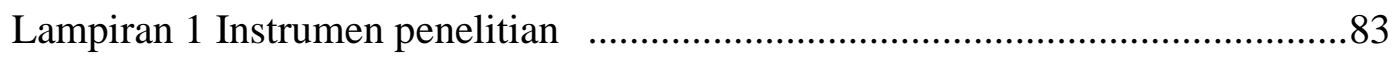

Lampiran 2 Transkip Wawancara ...............................................................94

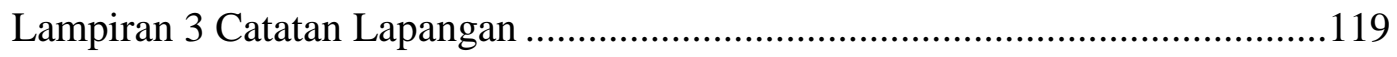

Lampiran 4 Foto-foto Penelitian .......................................................................121

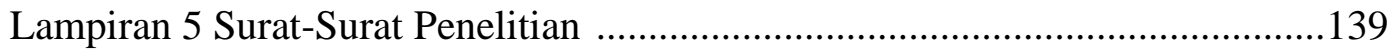

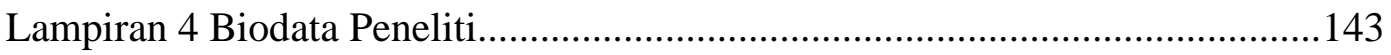




\section{BAB I}

\section{PENDAHULUAN}

\subsection{Latar Belakang Masalah}

Kesenian merupakan salah satu bagian penting dan tidak pernah lepas dari masyarakat, sebab kesenian merupakan sarana untuk mewujudkan segala bentuk ungkapan kreatifitas manusia. Kesenian dipandang sebagai unsur dalam kebudayaan, atau subsistem dari kebudayaan, hal ini terlihat dari fungsinya dalam kehidupan manusia. Kesenian sebagaimana juga kebudayaan, dilihat kesejajaran konsepnya, adalah pedoman hidup bagi masyarakat pendukungnya dalam mengadakan kegiatan yang di dalamnya berisikan perangkat-perangkat model kognisi (Rohidi, 2000: 10).

Koentjaraningrat (1992: 2) menjelaskan bahwa, unsur-unsur terbesar yang terjadi karena pecahan tahap pertama yang disebut "unsur-unsur kebudayaan yang universal", dan merupakan unsur-unsur yang pasti ditemukan di semua kebudayaan di dunia, baik yang hidup dalam masyrakat pedesaan yang kecil terpencil maupun dalam masyarakat kekotaan yang besar dan kompleks. Unsurunsur universal itu, yang sekalian merupakan isi dari semua kebudayaan yang ada di dunia ini, adalah: (1) Sistem religi dan upacara keagamaan, (2) Sistem dan organisasi kemasyarakatan, (3) Sistem pengetahuan, (4) Bahasa, (5) Kesenian, (6) Sistem mata pencaharian hidup, dan (7) Sistem teknologi dan peralatan.

Menurut Hardjana (1983: 34), keindahan dalam musik terjadi bukan saja atau sama sekali akibat kebutuhan manusia, tetapi karena kesadaran manusia akan 
bunyi dan waktu. Dampak kesadaran tersebut membentuk perbandinganperbandingan dan perbedaan-perbedaan. Oleh karena kesadaran tersebut, musik memiliki beberapa fungsi di dalam kehidupan manusia. Diantaranya, musik berfungsi sebagai media ekspresi, hiburan, pendidikan, ekonomi atau industri, iringan tarian, upacara, religi dan lain sebagainya.

Salah satu peran musik adalah sebagai media ekspresi dalam upacara religi, salah satunya di dalam ibadah umat Kristiani. Tim Badan Pekerja Majelis Sinode Gereja Kristen Indonesia BPMS GKI (2012: 1) menambahkan bahwa dalam ibadah, hampir semua bagian Kebaktian Minggu, melibatkan unsur musik, baik vokal maupun instrumental. Musik ibadah bukan sebagai aksesoris yang berfungsi untuk memperindah rangkaian acara ibadah saja, bukan juga sebagai rutinitas yang harus ada di dalam ibadah, apalagi sebagai sajian yang dapat dinikmati atau ditonton oleh jemaat, melainkan musik ibadah memiliki nilai yang sangat tinggi, karena musik ibadah diharapkan menuntun jemaat mempersiapkan diri masuk ke dalam suasana hikmat untuk merasakan kehadiran Tuhan.

Tim Badan Pekerja Majelis Sinode Gereja Kristen Indonesia BPMS GKI (2012: 7) juga menyatakan bahwa musik ibadah telah ada sejak dahulu, hal tersebut juga dipertegas dalam Alkitab yang menceritakan bahwa Musa dan bangsa Israel menyanyikan lagu kemenangan atas Mesir (Keluaran 15:1-21) dan menyanyikan lagu syukur atas air yang diberikan Tuhan (Bilangan 21:17). Dalam dua peristiwa itu banyak orang ikut serta merayakan karya besar Tuhan. Pada masa itu juga disebutkan bahwa suku Lewi ditetapkan sebagai petugas di rumah 
Tuhan sehingga muncul tradisi yang kuat bahwa ibadah harus dipersiapkan dengan baik agar dapat berjalan dengan hikmat.

Contoh tradisi sebelum melakukan ibadah adalah, bahwa suku Lewi mengatur dan membagi tugas masing-masing orang yang terlibat dalam ibadah tersebut, salah satunya perangakat yang harus ada dalam ibadah tersebut yaitu petugas kelompok musik (baca I Tawarikh 6:31-32; I Tawarikh 23: 5; 25: 1-8). Kelompok musik ini bukan kelompok yang hanya sekedarnya atau seadanya saja, melainkan sebuah kelompok yang mempunyai tanggung jawab dengan sungguhsungguh melaksanakan tugasnya seperti yang tertulis pada Alkitab, I Tawarikh 25: 7 yang berbunyi, "Jumlah mereka bersama-sama saudara-saudara mereka yang telah dilatih bernyanyi untuk Tuhan mereka sekalian adalah ahli seni ada dua ratus delapan puluh delapan orang', Lembaga Alkitab Indonesia (2000: 480).

Kelompok musik gereja sangat membutuhkan seseorang yang bertanggung jawab atas penyelenggaraan musik dalam ibadah yang disebut procantor. "Seorang procantor semestinya adalah seorang yang dapat memimpin, memandu dan menolong umat menaikkan puji-pujian kepada Tuhan dengan baik" (Tim Badan Pekerja Majelis Sinode Gereja Kristen Indonesia BPMS GKI, 2012: 98). Kemampuan untuk memimpin nyanyian jemaat dengan lengkap disebut cantorship, sedangkan seorang dan atau kelompok yang berperan sebagai penyanyi tunggal dan bertugas menyanyikan bagian-bagian tertentu dalam nyanyian atau menyanyikan nyanyian tertentu dalam suatu ibadah disebut cantor. Namun istilah tersebut tidak ditemukan di lingkungan Gereja Kristen Jawa (GKJ) 
melainkan menggunakan istilah Pemandu Nyanyian Jemaat (PNJ) yang juga memiliki fungsi yang sama dengan procantor.

Menurut Tim Badan Pekerja Majelis Sinode Gereja Kristen Indonesia BPMS GKI (2012: 101) procantor harus mampu bekerja sama dengan Pemandu Nyanyian Jemaat, Pendeta, Penatua dan umat. Lagu yang dipilih dalam nyanyian jemaat memiliki peran yang sangat penting, yaitu sebagai penuntun untuk membantu jemaat melakukan perjumpaan dengan Tuhan dalam peribadahan. Oleh karena itu apabila musik iringan tidak disiapkan dengan baik, maka dapat mengganggu jalannya ibadah. Pemandu Nyanyian Jemaat (PNJ) perlu memiliki kompetensi dan pengetahuan yang memadai mengenai nyanyian jemaat.

Bentuk nyanyian jemaat dan masing-masing memiliki ciri-ciri masingmasing. Salah satunya adalah hymn, menurut Tim Badan Pekerja Majelis Sinode Gereja Kristen Indonesia BPMS GKI (2012: 16) bahwa hymn adalah nyanyian yang berisi pujian kepada Tuhan. Untuk itu pemahaman mengenai hymnology amat penting, hymnology adalah ilmu yang mempelajari musik gereja yang digunakan dan dinyanyikan oleh umat Kristiani dalam ibadah.

Nyanyian jemaat merupakan bagian dari musik gereja yang menjadi satu dengan liturgi, artinya setiap unsur dalam liturgi itu terangkai satu dengan yang lainnya membentuk satu kesatuan pemahaman iman yang diyakini umat, yaitu keyakinan akan keselamatan anugerah Allah atas manusia (Tim Sinode GKJ, tanpa tahun: 7). Pemusik dan PNJ merupakan bagian dari liturgi dan berperan sebagai sarana yang bertujuan membuat suasana menjadi hikmat sehingga mampu membawa umat pada tahap perjumpaan dengan Allah. 
Dalam mewujudkan perannya, pemusik perlu memiliki kompetensi yang memadahi (Tim Badan Pekerja Majelis Sinode Gereja Kristen Indonesia BPMS GKI, 2012: 45). Namun di GKJ, khususnya GKJ Ngesrep, hal ini kurang menjadi perhatian. PNJ hanya melakukan tugasnya sesuai jadwal tanpa memahami hakekatnya sebagai seorang Pemandu pujian yang memiliki peranan penting dalam ibadah. Hal ini berakibat PNJ melakukan tugasnya tanpa persiapan, sehingga dianggap kurang mampu melaksanakan peran, yaitu membawa umat pada perjumpaan dengan Allah selama peribadatan. Seorang PNJ tidak hanya dituntut bisa bernyanyi dengan lantang saja, namun juga harus memperhatikan notasi musik dan syair dari nyanyiannya agar bisa menuntun jemaat melakukan perjumpaan dengan Tuhan melalui nyanyian.

Menurut Soewito (1996: 11), ada beberapa unsur yang harus diperhatikan dalam bernyanyi unison (satu suara), unsur tersebut terdiri dari : balancing, artikulasi, notasi, dinamika, dan tempo. Namun hal ini tidak ditemukan dalam PNJ GKJ Ngresep. Masing-masing PNJ masih ada yang kurang tepat ketika membaca notasi musik. Sementara jemaat saat ini menyanyi berdasarkan pengalaman mendengarkan suatu nyanyian yang sudah dinyanyikan sejak dahulu tanpa mempelajari notasi aslinya, lebih lagi gereja telah menyediakan fasilitas multimedia yang menampilkan syair dari nyanyian namun terkadang tidak disertai notasi musiknya. Di dalam keadaan seperti ini PNJ menjadi panutan jemaat dalam bernyanyi. Kehadiran pemusik dan PNJ di tengah-tengah jemaat seharusnya mampu mendorong jemaat untuk mau dan dapat bernyanyi dengan baik (Tim Badan Pekerja Majelis Sinode Gereja Kristen Indonesia BPMS GKI: 2012). 
Bernyanyi dengan baik salah satunya adalah dengan tempo yang tepat. Selama observasi pendahuluan di GKJ Ngesrep berlangsung, nyanyian di dalam ibadah Minggu, selama bulan Mei 2017 memiliki tempo yang hampir sama mulai dari nyanyian pembukaan hingga pengutusan. Padahal setiap nyanyian memiliki pesan sendiri-sendiri dan sebaiknya pesan tersebut dapat diinterpretasikan dengan baik oleh PNJ dan pemusik (organis/pianis). Hal lain yang kurang mendorong jemaat bernyanyi dengan baik adalah pemusik dan PNJ di GKJ Ngesrep masih ragu ketika memulai nyanyian, terutama pada awal nyanyian yaitu setelah intro dimainkan. Misalkan notasi pada partitur menunjukkan bahwa jemaat bernyanyi pada ketukan pertama, namun pada ketukan satu (irama gantung) atau bahkan ketukan kedua jemaat baru bernyanyi. Seperti saling menunggu antara jemaat, pemusik dan PNJ untuk mulai bernyanyi. Hal seperti ini sangat mengurangi keindahan dari nyanyian yang tentunya memiliki pesan khusus di dalam sebuah ibadah. Selain itu dibutuhkan artikulasi dan dinamika yang tepat sesuai lagu yang dibawakan untuk dapat menghantarkan jemaat supaya lebih hikmat.

Berdasarkan dari uraian di atas bahwasanya unsur utama dalam musik vokal yaitu teknik bernyanyi yang di dalamnya terdapat teknik balancing, artikulasi, notasi, dinamika, dan tempo dalam hal ini apabilah salah satu dari teknik tersebut tidak dapat terpenuhi maka akan berpengaruh pada kualitas vokal yang dinyanyikan dari para penyanyi. Sejalan dengan hal tersebut dari hasil observasi peneliti, dimana peneliti melihat banyak kesalahan teknik pada saat singer yang menjadi petugas di GKJ Ngesrep, sedang melakukan tugasnya yaitub bernyanyi pada saat peribadatan. Karena pentingnya sebuah teknik di dalam 
bernyanyi sangat diutamakan agar pendengar atau jemaaat yang mendengarkan singer bernyanyi bisa mengahayti dan mengerti apa dari maksud lagu yang dinyanyikan karna hal ini juga berkaitan dengan nyanyian peribadatan di dalam gereja.

Sepengetahuan peneliti belum ditemukan penelitian yang membahas tentang Teknik Vokal dan Peran Pemandu Nyanyian Jemaat dalam Ibadah di GKJ Ngesrep. Namun penelitian yang sejenis dilakukan oleh Septian Galih Candra Hermawan dengan judul "Transformasi Musik Gerejawi” (Penelitian Terhadap Tradisi Musik Gerejawi dalam Ibadah Minggu di GKJW TulungrejoBanyuwangi), dengan kesimpulan bahwa musik dan nyanyian dipahami sebagai bagian yang penting dan tak terpisahkan dalam kehidupan persekutuan umat Kristen. Musik dalam ibadah minggu berperan sebagai sarana untuk memberikan respon kasih Allah terhadap dunia, sarana untuk mengungkapkan isi hati dan sebagai sarana untuk belajar mengenai dasar dasar iman. Namun pada kenyataannya iringan musik dan nyanyian di dalam ibadah minggu di GKJW Tulungrejo-Banyuwangi kurang memberikan peran yang maksimal, terlalu monoton dan tidak ada perubahan yang maksimal dari waktu ke waktu. Sebaiknya gereja memberikan perhatian secara khusus terhadap iringan musik dan nyanyian di dalam ibadah minggu.

Peneliti juga mengacu pada penelitian tentang "Peran dan Fungsi Nyanyian Proprium dan Ordinarium Masa Biasa Dalam Tata Perayaan Ekaristi Gereja Katolik Di Paroki Santo Yohanes Rasul Pringwulung Yogyakarta” oleh Yustinus Genohan Tukan. Hasil penelitian menyatakan bahwa, meskipun belum 
semua memahami secara baik peran dan fungsi nyanyian dalam perayaan Ekaristi, namun tetap menunjukkan semangat dalam bernyanyi serta rasa hormat yang tinggi ketika mengikuti peryaan Ekaristi.

Dari penjelasan tersebut, penelitian dari Hermawan menjadi acuan peneliti untuk melihat bagaimana peran musik iringan dalam ibadah minggu. Penelitian pertama, yaitu penelitian dari Nariswari menjadi acuan peneliti untuk melihat bagaimana partisipasi aktif dan kerjasama antara pemusik dengan Pemandu Nyanyian Jemaat. Sedangkan penelitian kedua, yaitu penelitian Tukan dipakai peneliti sebagai bahan acuan dalam menyusun kerangka penelitian. Peneliti menganggap ketiga penelitian tersebut relevan dengan penelitian Teknik Vokal dan Pemandu Nyanyian Jemaat dalam Ibadah.

Berdasarkan pada latar belakang dan permasalahan tersebut, maka peneliti tertarik untuk meneliti permasalahan yang ada yaitu Bagaimanakah Teknik vokal dalam nyanyian peribadatan di GKJ Ngesrep dan bagaimanakah peran Pemandu Nyanyian Jemaat pada proses peribadatan di GKJ Ngersep.

\subsection{Rumusan Masalah}

Berdasarkan uraian latar belakang masalah dan penelitian ini lebih terpusat , maka fokus masalah dalam penelitian ini adalah

1.2.1 Bagaimanakah teknik vokal dalam nyanyian peribadatan di GKJ Ngesrep?

1.2.2 Bagaimanakah peran Pemandu Nyanyian Jemaat pada proses peribadatan di GKJ Ngesrep? 


\subsection{Tujuan Penelitian}

Sesuai dengan rumusan masalah yang ada, maka tujuan dari penelitian ini adalah untuk mengetahui, mendeskripsikan, dan, menganalisis:

1.3.1 Teknik vokal dalam nyanyian peribadatan di GKJ Ngesrep.

1.3.2 Peran Pemandu Nyanyian Jemaat pada proses peribadatan di GKJ Ngesrep.

\subsection{Manfaat Penelitian}

Dalam penelitian ini terdapat dua manfaat yaitu Manfaat teoritis dan Manfaat praktis, berikut penjabaran manfaat tersebut,

\subsubsection{Manfaat Teoritis}

Hasil penelitian ini (1). Dapat menjadikan bahan referensi penting dalam kepustakaan seni musik Khusunya musik ibadah gereja. (2). Sebagai pengembangan teori mengenai isi dari teknik vokal dan peran Pemandu Nyanyian Jemaat khususnya GKJ Ngesrep.

\subsubsection{Manfaat Praktis}

Manfaat praktis hasil penelitian ini sebagai berikut : (1). Hasil penelitian ini dapat menjadi acuan kepada musik gereja khususnya GKJ Ngesrep tentang teknik vokal dalam nyanyian peribadatan gerejawi, dan bagaimanakah peran Pemandu Nyanyian Jemaat pada proses peribadatan di GKJ Ngesrep. (2). Hasil penelitian ini dapat memberikan sumbangan praktis tentang bentuk penyajia n vokal serta peran Pemandu Nyanyian Jemaat di greja khususnya GKJ Ngesrep. (3). Hasil penelitian ini memberikan pandangan secara kompherensif akan 
pentingnya pendidikan dalam dunia seni musik khususnya bagi musik gereja di GKJ Ngesrep. (4). Menambah wawasan mahasiswa pendidikan seni musik tentang peran Pemandu Nyanyian Jemaat dalam ibadah di gereja. 


\subsection{Sistematika Penulisan}

Sistematika penulisan skripsi disusun dengan tujuan agar pokok-pokok masalah dapat dibahas secara urut dan terarah. Adapun sistematika penulisan skripsi terdiri dari tiga bagian. Bagian awal berisi tentang: Judul, Pengesahan, Surat Pernyataan, Motto dan Persembahan, Sari, Kata Pengantar, Daftar Isi. Bagian isi terdiri dari 5 bab, yaitu:

BAB I, Pendahuluan, yang berisi tentang latar belakang masalah, rumusan masalah, tujuan penelitian, Manfaat penelitian, dan sistematika skripsi.

BAB II, Landasan teori yang terdiri dari persepsi, teori yang digunakan sebagai landasan penelitian yang berisi telaah pustaka yang menjelaskan tentang Teknik Vokal dan Peran Pemandu Jemaat GKJ Ngesrep.

BAB III, Metode penelitian, berisi tentang pendekatan penelitian, lokasi penelitian, sasaran penelitian, teknik pengumpulan data yang meliputi teknik observasi, wawancara, dokumentasi, teknik analisis data dan teknik pemeriksaan keabsahan data.

BAB IV, Hasil penelitian dan pembahasan yang mencakup tentang gambaran umum lokasi penelitian, Teknik Vokal Pemandu Nyanyian Jemaat GKJ Ngesrep dan Peran Pemandu Nyanyian Jemaat GKJ Ngesrep.

BAB V, Penutup berisi simpulan dan saran.

Bagian akhir skripsi, berisi tentang daftar pustaka yang digunakan sebagai bahan supervisi penelitian, dan lampiran kelengkapan surat-surat penelitian. 


\section{BAB II}

\section{KAJIAN PUSTAKA DAN LANDASAN TEORI}

\subsection{Kajian Pustaka}

Penelitian yang sejenis dari peneliti terdahulu mengenai teknik vokal dan peran Pemandu Nyanyian Jemaat dilakukan oleh Firsta Kris Martian, (2009) dengan judul "Pembelajaran Vokal Pada Paduan Suara Adiyuswo Di Gereja Kristen Jawa Limpung Pepanthan Subah Kabupaten Batang”, dengan kesimpulan pembelajaran paduan suara Adiyuswo GKJ Subah dilkukan dalam tiga tahap yaitu pendahuluan, penyajian dan penutup. Substansi yang peneliti dapat dari penelitian tersebut adalah objek materialnya sama-sama membahas tentang musik vokal gereja, adapun yang membedakan letak penelitian tersebut adalah pada penelitian tersebut mengangkat tentang pembelajaran pada paduan suara di GKJ Subah, sedangkan peneliti mengangkat tentang Teknik Vokal dan peran Pemandu Nyanyian Jemaat di GKJ Ngesrep.

Stefanus Sugiman dkk, (2017) dalam bukunya "Membentuk Karakter Jemaat yang Melayani Sebagai Perwujudan Kasih Tuhan” buku ini berisikan tentang profil data mengenai GKJ Ngesrep yang membahas program kerja dan program pelayanan di GKJ Ngesrep. Substansi yang peneliti dapatkan dari peneliti tersebut ialah kaitannya dengan objek material yang peneliti angkat, yang membedakannya adalah permasalahan yang peneliti angkat Teknik Vokal dan Peran Pemandu Nyanyian Jemaat. 
Andaru Akrom Ekaputri, dengan judul "Pengaruh Olah vokal Bernyanyi terhadap kemampuan Olah Vokal drama" di dalam jurnal ini membahasa tentang teknik teknik vokal dalam bernyanyi dan untuk mengetahu seberapa besar pengaruh olah vokal pada drama. Adapun substansi yang didapat pada peneliti yaitu sama-sama membahas tentang musik vokal, dan yang membedakan pada objek materialnya.

Cahyo Sukrisno Putra, (2015) dengan judul "Pembelajaran Vokal Dengan Metode Solfegio Pada Paduan Suara Gracia Gitaswara di GKJ Cilacap Utara Kabupaten Cilacap", di dalam skripsi ini berisikan tentang eksistensi paduan suara gracia gitaswara yang ada dan selalu dinantikan keberadaannya dalam setiap kesempatan dalam ruang lingkup GKJ Cilacap Utara. Keunikan yang ada di dalam cara pembelajarannya yaitu dengan metode solfegio, yang mana dengan metode solfegio anggota paduan suara semakin cepat dan akurat dalam membaca notasi. Dari penelitian tersebut ditunjukkan bahwa pembelajaran vokal dengan menggunakan metode solfegio pada paduan suara gracia gitaswara di GKJ Cilacap Utara untuk mencapai paduan suara yang baik diperlukan perencanaan dan pelakanaan yang tepat dalam proses pembelajaran vokal paduan suara. Adapun substansi yang peneliti dapat dari penelitian tersebut adalah terletak pada objek materialnya yang sama-sama mengangkat musik vokal gereja, yang membedakannya dalam penelitian ini adalah pada permasalahan yang diangkat peneliti dimana penliti mengkaji tentang Teknik Vokal dan peran Pemandu Nyanyian Jemaat di GKJ Ngesrep, sedangkan peneliti terdahulu mengangkat 
tentang latihan dan pembelajaran solfegio pada paduan suara gracia gitaswara di GKJ Cilacap Utara.

Lembaga Alkitab Indonesia, (2000) dengan judul buku "Alkitab dengan Kidung Jemaat" yang berisikan tentang ajaran-ajaran umat Kristiani baik dalam peribadatan gereja maupun dalam kehidupan sehai-hari dan berisikan materimateri lagu dalam ibadah yang berkaitan dengan objek material yang peneliti angkat yaitu tentang musik greja, yang membedakannya adalah terletak pada permasalahan yang peneliti angkat adalah teknik vokal dan peran Pemandu Nyanyian Jemaat di GKJ Ngesrep.

Septian Galih Candra Hermawan dengan judul "Transformasi Musik Gerejawi" (Penelitian Terhadap Tradisi Musik Gerejawi dalam Ibadah Minggu di GKJW Tulungrejo-Banyuwangi), dengan kesimpulan bahwa musik dan nyanyian dipahami sebagai bagian yang penting dan tak terpisahkan dalam kehidupan persekutuan umat Kristen. Musik dalam ibadah minggu berperan sebagai sarana untuk memberikan respon kasih Allah terhadap dunia, sarana untuk mengungkapkan isi hati dan sebagai sarana untuk belajar mengenai dasar dasar iman. Namun pada kenyataannya iringan musik dan nyanyian di dalam ibadah minggu di GKJW Tulungrejo-Banyuwangi kurang memberikan peran yang maksimal, terlalu monoton dan tidak ada perubahan yang maksimal dari waktu ke waktu. Sebaiknya gereja memberikan perhatian secara khusus terhadap iringan musik dan nyanyian di dalam ibadah minggu.

Peneliti juga mengacu pada penelitian tentang "Peran dan Fungsi Nyanyian Proprium dan Ordinarium Masa Biasa Dalam Tata Perayaan Ekaristi 
Gereja Katolik Di Paroki Santo Yohanes Rasul Pringwulung Yogyakarta” oleh Yustinus Genohan Tukan. Hasil penelitian menyatakan bahwa, meskipun belum semua memahami secara baik peran dan fungsi nyanyian dalam perayaan Ekaristi, namun tetap menunjukkan semangat dalam bernyanyi serta rasa hormat yang tinggi ketika mengikuti perayaan Ekaristi.

Argo Binantoro, (2014) yang berjudul "Fungsi Bentuk Penyajian Musik Cengklungan Pada Paguyuban Podho Rukun Desa Geblog Kaloran Temanggung”. Hasil penelitian membahas tentang Musik vokal, yang membedakan adalah pada objek materialnya penelitian ini meneliti bentuk penyajian musik cengklungan dengan pola penyajiannya terdiri dari 3 sinden, 3 orang pemain cengklungan, dan satu pemain seruling yang ditampilkan dengan inovasi baru yaitu menggunakan tangga nada slendro kemudian beralih ke nada pelog.

Peneliti juga mengacu pada penelitian tentang "Analisis Pengaruh Nyanyian Jemaat Terhadap Kualitas Ibadah Gereja Protestan di Indonesia bagian Barat (GPIB) Jemaat Bukit Zaitun Makassar". Dari hasil penelitian menunjukkan bahwa jemaat tidak sepenuhnya tahu, kenal, dan sadar akan hakikat nyanyian dalam ibadah. Jemaat banyak tidak memahami hubungan nyanyian dengan liturgi. Adapun yang membedakan letak penelitian tersebut adalah pada kajian objek materialnya, namun penelitian ini sama-sama mengkaji musik gereja.

Yenni Lukita Sari, (2013) dengan judul "Fungsi dan Bentuk Penyajian Musik Thillung di Dagaran Jurug Sewon Bantul”, dengan kesimpulan bentuk penyajian musik thillung adalah ansambel musik, karena menggunakan sepuluh 
macam instrumen yang berbeda, dan fungsi dari musik thillung itu sendiri dibagi menjadi 2 , yaitu fungsi bagi masyarakat dan fungsi bagi pemain musik thilung itu sendiri. Persamaan dari penelitian ini adalah sama-sama mengkaji tentang musik dan yang membedakan penelitian ini adalah pada objek materialnya, penelitian yang akan peneliti teliti mengkaji tentang musik vokal, sedangkan penelitian dari Yenni tentang musik thillung.

Penelitian yang sejenis dari peneliti terdahulu mengenai bentuk penyajian juga dilakukan oleh Abdul Majid tentang "Ekistensi, Bentuk Penyajian dan Fungsi Kesenian Tradisional Orek-orek di Kabupaten Rembang”, dengan kesimpulan bentuk penyajian kesenian orek-orek meliputi gerak tari, iringan gamelan, tata rias, busana, pola lantai, dan tempat pertunjukan. Adapun fungsi dari kesenian tradisi orek-orek tersebut terbagi menjadi 2 yaitu fungsi religi dan fungsi hiburan. Perbedaan dari penelitian tersebut adalah dari objek materialnya yang meneliti kesenian tradisi orek-orek, dan yang peneliti kaji adalah teknik vokal di GKJ Ngesrep.

Putut Sulasmono dalam jurnal Harmonia Volume 13 No 1/ Juni 2013 Dengan judul Peningkatan kemampuan vokal melalui metode solfegio penelitian ini berisikan tentang peningkatan aktifitas belajar vokal melalui metode solfegio adapun kesamaan dalam penelitian ini yaitu sama-sama mengacu pada musik vokal akan tetapi yang membedakan adalah pada kajiannya.

Berdasarkan penjelasan tersebut, penelitian dari Hermawan menjadi acuan peneliti untuk melihat bagaimana peran musik iringan dalam ibadah minggu dan menjadi acuan peneliti untuk melihat bagaimana partisipasi aktif dan kerjasama 
antara pemusik dengan Pemandu Nyanyian Jemaat, sedangkan penelitian kedua, yaitu penelitian Tukan dipakai peneliti sebagai bahan acuan dalam menyusun kerangka penelitian. Peneliti menganggap kedua penelitian tersebut relevan dengan penelitian Peran Musik Iringan dan Pemandu Nyanyian Jemaat dalam Ibadah.

\subsection{Landasan Teori}

Teori yang dipergunakan peneliti dalam melakukan penelitian tentang Bagaimanakah teknik vokal dalam nyanyian peribadatan di GKJ Ngesrep dan bagaimanakah peran Pemandu Nyanyian Jemaat pada proses peribadatan di GKJ Ngersep adalah sebagai berikut:

\subsubsection{Teknik Vokal}

Menurut Soewito (1996: 11), ada beberapa unsur yang harus diperhatikan dalam bernyanyi, unsur-unsur tersebut terdiri dari sikap tubuh yang baik, cara bernafas, cara mengucapkan, dan cara memproduksi suara dengan intonasi yang baik yang disebut teknik vokal. Peningkatan teknik vokal, pada dasarnya sulit dilakukan, apabila tidak dilatih, diasah dan dicoba secara teratur (Pramayudha, 2010: 65). Namun, hal itu bisa dilakukan jika menggunakan beberapa teknik dalam bernyanyi yang disebut teknik vokal. Berikut ini akan disampaikan beberapa teknik vokal.

\subsubsection{Pernapasan}

Menurut Soewito (1996: 11), pernapasan merupakan unsur terpenting dalam bernyanyi. Ada 3 jenis pernapasan dalam bernyanyi, yaitu pernapasan dada, 
pernapasan perut, dan pernapasan diafragma. Jenis teknik pernapasan yang dikemukakan oleh Rahardjo (1990: 36) ada lima, yaitu: teknik pernapasan tulang selangka, teknik pernapasan tulang rusuk, teknik pernapasan perut, teknik pernapasan dada, dan teknik pernapasan diafragma. Selain itu, Jamalus (1988: 50) mengatakan bahwa ada 3 jenis pernapasan yang sering digunakan dalam bernyanyi. Pernapasan-pernapasan tersebut adalah: (1). Pernapasan Dada; Pernapasan ini dilakukan dengan cara memasukkan udara ke dalam paru-paru sehingga paru-paru menjadi lebih besar. Pernapasan dada tidak baik digunakan dalam bernyanyi. (2). Pernapasan Perut; Pernapasan ini disebabkan oleh gerakan perut yang semakin mengembang, rongga perut membesar sehingga udara dari luar masuk memenuhi perut. Rongga dada bebas dari ketegangan. Paru-paru, batang tenggorokan, selaput suara, alat-alat pengucapan, dapat leluasa menghasilkan suara yang wajar. Akan tetapi,tidak memberikan dorongan yang kuat. Pernapasan perut ini pun tidak baik digunakan untuk benyanyi. (3). Pernapasan Diafragma; Diafragma terletak di antara rongga dada dan rongga perut. Pada saat bernyanyi, otot diafragma dapat memberi dorongan yang kuat kepada paru-paru serta dapat mengatur tenaga aliran udara melalui batang tenggorokan menggetarkan selaput suara dan keluar melalui mulut. Pernapasan yang baik digunakan untuk bernyanyi ialah pernapasan diafragma.

Selain 3 jenis pernapasan di atas, pernapasan bahu juga merupakan salah satu pernapasan yang digunakan dalam bernyanyi. Pramayuda (2010: 67) mengungkapkan bahwa pernapasan bahu adalah pernapasan yang mengambil atau mengalihkan/ mengangkat kekuatan bahu, untuk mengisi napas pada paru-paru, 
sebab pusat napas adalah di paru-paru. Pernapasan ini tidak baik digunakan dalam bernyanyi. Kemudian Ada beberapa tanda yang dijadikan pegangan dan bisa dirasakan saat pernapasan diafragma (Widyastuti, 2007: 9), yaitu: seperti di atas, kita akan merasakan telapak tangan terdorong ke luar.

Dari beberapa pendapat di atas, dapat disimpulkan bahwa pernapasan adalah unsur terpenting dalam bernyanyi. Ada 4 jenis pernapasan dalam bernyanyi, yaitu pernapasan dada, pernapasan bahu, pernapasan perut, dan pernapasan diafragma. Dari ke 4 jenis pernapasan tersebut, pernapasan yang baik digunakan dalam bernyanyi adalah pernapasan diafragma. Diafragm terletak di antara rongga dada dan rongga perut, dan dilakukan dengan cara menarik atau mengambil napas untuk mengisi paru-paru dengan mengembangkan rongga perut dan mengembangkan tulang rusuk. Pernapasan diafragma paling baik digunakan karena akan menghasilkan napas yang panjang ringan, santai, dan produksi suara lebih bermutu.

\subsubsection{Pengucapan/Artikulasi}

Berkaitan dengan bernyanyi Pramayudha (2010: 81), mengatakan bahwa bernyanyi adalah berbicara melalui syair lagu yang memiliki notasi/melodi/irama/ dan birama dan di dalam syairnya terkandung pesan, cerita, yang harus disampaik an kepada pendengar dan harus dapat dimengerti yang disebut artikulasi. Hal tersebut juga dipertegas oleh Soewito (1996: 15) mengatakan bahwa pengucapan atau artikulasi sangat penting dalam bernyanyi. Kata-kata harus diucapkan dengan baik dan jelas. Kemudian Tim Pusat Musik Liturgi (1992: 56), menyatakan bahwa: "Bernyanyi dengan kata-kata. Agar pesan dari kata-kata itu dapat 
dimengerti, maka sebagai penyanyi kita harus meningkatkan ucapan kata, karena kata-kata yang dinyanyikan, mudah menjadi kabur. Apalagi dalam bernyanyi bersama, cara membentuk huruf hidup dan mati harus sama, dan seragam hingga nampak kesatuan dari paduan suara.”

Berdasakan pemaparan di atas mengenai artikulasi Widyastuti (2007: 16), menyatakan bahwa artikulasi terbagi atas 3, yaitu artikulasi huruf vokal, artikulasi huruf konsonan, dan artikulasi huruf vokal rangkap/diftong. Berikut penjelasan ketiga artikulasi tersebut:

\section{a. Artikulasi Vokal (huruf hidup)}

Berdasarkan 5 jenis vokal yang diketahui, yaitu a, i, u, e dan o. Kelima huruf ini yang membangun semua kata-kata dalam bahasa Indonesia dan juga bahasa asing lainnya. Berikut latihan kelima vokal tersebut : (1) Vokal A, dengan teknik lemaskan lidah, letakkan lidah rata di atas mulut sehingga sisi-sisi lidah menyentuh pangkal gusi, ujung lidah menyentuh akar gigi bawah. Kemudian ucapkan "A" dengan membuka mulut dan menurunkan rahang bawah. Bagian belakang mulut (parynx) dan bagian depan mulut (bibir) akan terbuka, dan yang selanjutnya bentuk bibir atas dan bawah pada bagian depan mulut terbuka membentuk corong yang bulat.

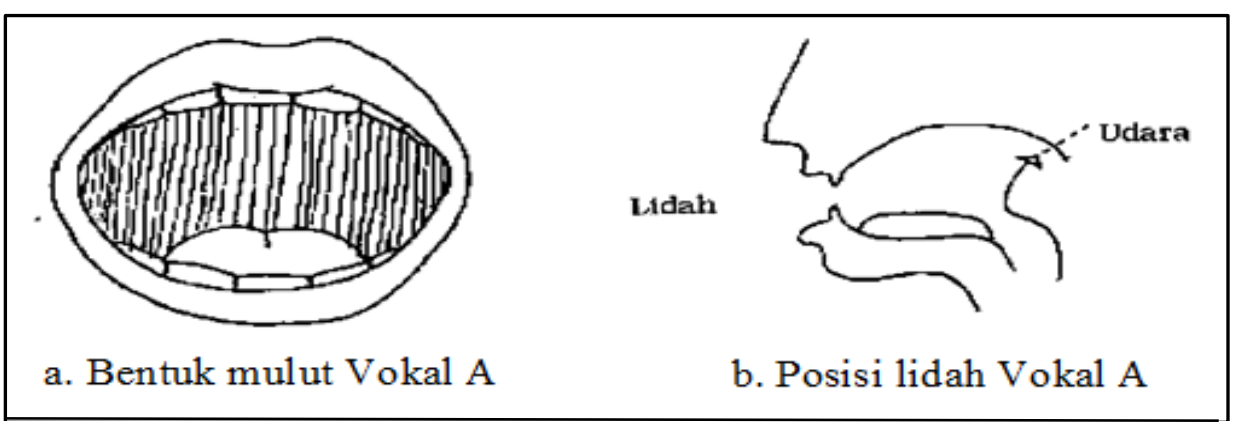

Gambarl. Bentuk mulut Vokal A dan Posisi lidahVokal A (Soewito, 1996: 16) 
Nyanyikan vokal "A" dengan permulaan lembut, sedikit demi sedikit menjadi keras kemudian diakhiri sedikit demi sedikit menjadi lembut. Adapun jenis vokal yang ke (2) yaitu Vokal "E" dengan teknik sebagi berikut: Mulut ditarik kesamping agak lebar dan ucapkan "E" dengan menurunkan rahang bawah sehingga memberi ruangan untuk membuat suara jernih dan terang. Kemudian yang harus dilakukan bibir jangan menjadi sempit tapi tetap seperti corong, untuk selanjutnya dengan posisi seperti ini ucapkan kembali vokal "E" dengan lembut, tidak perlu berteriak.

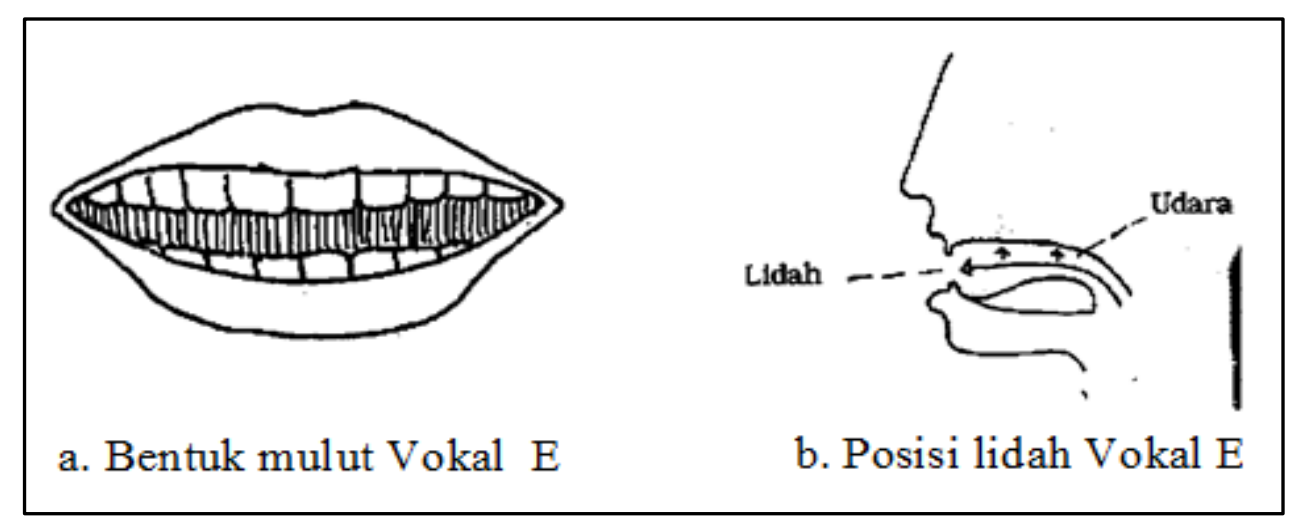

Gambar 2. Bentuk mulut Vokal E dan Posisi lidah Vokal E. (Soewito, 1996: 17)

Kemudian jenis yang ke (3) Vokal I, ujung lidah tetap berada dibelakang akar gigi bawah, namun bagian tengah dari lidah naik ke atas, dan ucapkan "I" dengan sudut bibir ditarik ke belakang. Kemudian gigi atas dan bawah sebaiknya kelihatan, selanjutnya bibir tetap dijaga membentuk corong sehingga kesan suara lebih terfokus, dengan posisi seperti ini ucapkan kembali vokal "I" dengan lembut dan rahang bawah jangan terlalu turun. 


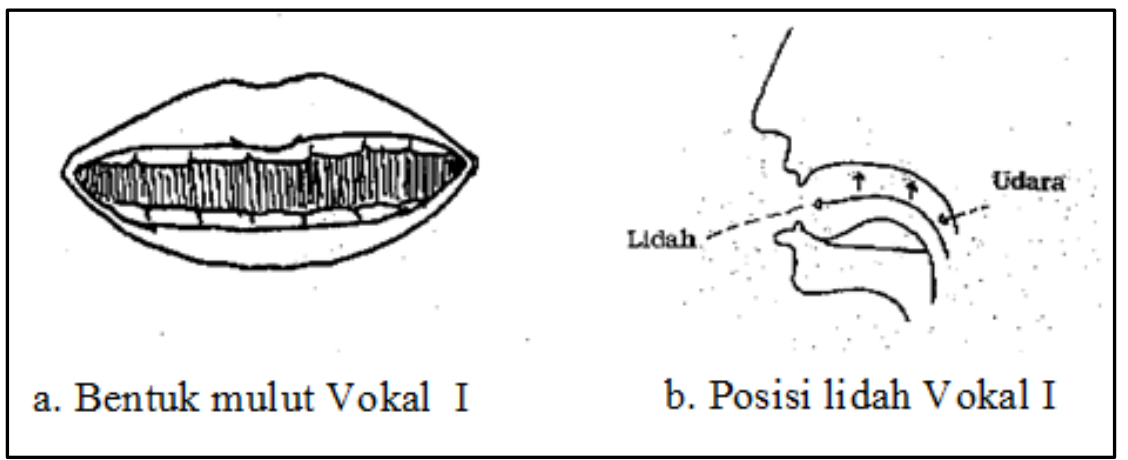

Gambar 3. Bentuk mulut Vokal I dan Posisi lidah Vokal I (Soewito, 1996: 18)

Adapun jenis yang ke (4) Vokal O dan Ô dengan posisi lidah tetap datar seperti pada huruf "A”. Kemudian ucapkan "O” seperti pada "toko", membentuk corong bibir diperpanjang, dan untuk vokal "Ô" seperti pada kata "mohon", bentuk corong bibir lebih bundar daripada huruf "O" pada kata "toko". Rahang lebih rendah dan tenggorokan dalam posisi lebih luas, dengan posisi seperti ini ucapkan kembali huruf "O” dengan memperluas ronggamulut.

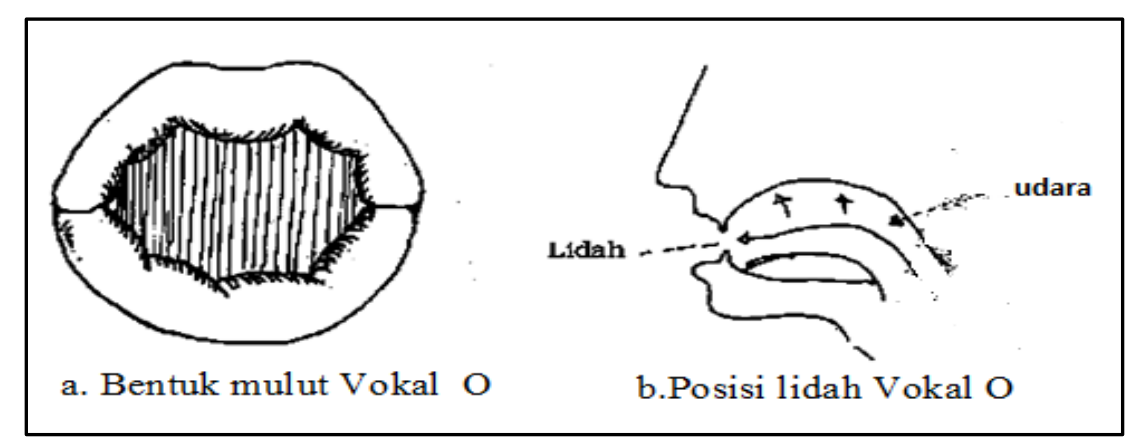

Gambar 4. Bentuk mulut Vokal O dan posisi lidah Vokal $O$ (Soewito, 1996: 19)

Jenis yang terakhir yaitu yang ke (5) Vokal U, bibir dimajukan ke depan membentuk corong yang dipersempit, tetapi tetap bundar, dan ujung lidah menyentuh akar gigi sedikit membusung di bagian belakang, kemudian rahang bawah turun secukupnya. Antara gigi atas dan gigi bawah diberi jarak kira-kira 1 ibu jari. 


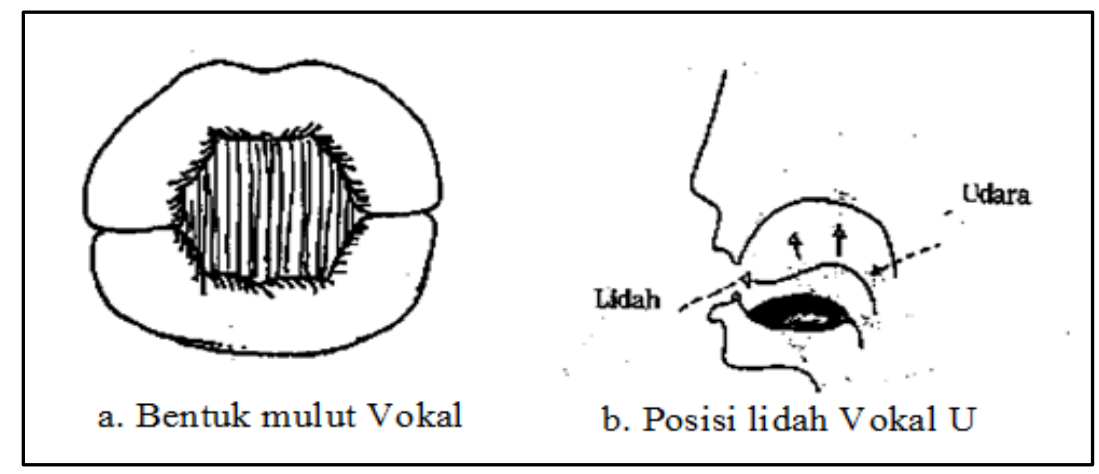

Gambar 5. Bentuk mulut Vokal Udan Posisi lidah Vokal U. (Soewito, 1996: 20)

\section{b. Artikulasi konsonan/Huruf mati}

Konsonan merupakan bunyi bantu untuk vokal/ huruf hidup, pengucapan satu dengan yang lainnya akan berbeda berdasarkan pembentukan bunyinya. Contoh : (1) Konsonan b, c, d, g, k, p, t disebut juga konsonan hambat oral, dibunyikan dengan membentuk 'hambatan" di mulut oleh alat bicara yang ada di mulut. (2) Konsonan 1, m, n, r, ng, disebut juga konsonan hambat nasal, dibunyikan dengan membentuk "hambatan" di nasal. Konsonan ini disebut juga huruf mati yang bersuara.

\section{c. Artikulasi Vokal Rangkap (Diftong)}

Diftong adalah bunyi dua vokal yang berurutan, keduanya berbeda antara kualitas huruf vokal awal dan akhirnya. Pengucapan setiap vokal memerlukan penyesuaian pada kerongkongan dan mulut. Dalam menyanyikan diftong, vokal pertama dinyanyikan lebih lama dari vokal keduanya, vokal yang mendahului diberi tekan sedikit kemudian berubah lebih rileks/luwes kebunyi vokal yang mengikutinya. Contoh : Diftong “ai” (permai, dawai, melambai), “au” (engkau, hijua, lampau), “oi” (amboina, sepoi-sepoi), “ia” (karunia, dunia), “ua” (semua). 
Berdasakan pendapat di atas, dapat disimpulkan bahwa artikulasi adalah bunyi yang berasal dari dalam mulut dan merupakan salah satu unsur yang sangat penting dalam bernyanyi, sehingga penyanyi harus meningkatkan ucapan katakata agar nampak kesatuan paduan suara.

\subsubsection{Resonansi}

Menurut Soewito (1996 : 15), resonansi berfungsi untuk memperluas dan memperindah suara sehingga terdengar merdu, nyaring dan menawan. Berkaitan dengan resonansi, Tim Pusat Musik Liturgi (1992: 34), Resonansi adalah suatu gejala 'bunyi kembali' dari suatu ruangan, dan dinding yang keras sehingga sanggup memantulkan suara. Resonansi menambah keindahan pada suara hingga menjadi bunyi yang gemilang". Namun pada waktu bernyanyi fungsinya semua sama yaitu rongga resonan menguatkan dan memperbesar getaran suara dari sumbernya (pita suara).

Menurut Rahardjo (1990: 13). Organ tubuh manusia yang berfungsi memantulkan getaran suara yang ditimbulkan oleh pita suara disebut resonator. Sedangkan fungsi resonator adalah membantu menguatkan getaran suara sehingga menjadi suara yang kuat. Organ-organ tubuh yang berfungsi sebagai resonator adalah rongga dada, rongga mulut, rongga hidung, rongga nasopharynxe, dan kepala. Fungsi dari semua rongga, terutama rongga yang dapat berubah ialah menimbulkan perbedaan warna suara. Semakin banyak udara yang termuat dalam rongga-rongga resonansi tersebut, maka semakin bulat suara yang ditimbulkan. Tim Pusat Musik Liturgi, (1992: 37). Dari beberapa pendapat di atas, dapat disimpulkan bahwa resonansi adalah suatu bunyi yang timbul dari suatu sumber 
getaran yang berongga, yang berfungsi untuk memperluas dan memperindah suara.

\subsubsection{Phrasering}

Menurut Soewito (1996: 22), phrasering ialah aturan pemenggalan kalimat bahasa atau kalimat musik menjadi bagian yang lebih pendek, tetapi tetap mempunyai kesatuan arti, sedangkan menurut Pradoko, phrasering adalah mengelompokkan bagian-bagian kalimat, baik untuk jenis potongan kalimat pertanyaan maupun kalimat jawaban (1997: 40).

Berdasarkan pendapat di atas, dapat disimpulkan bahwa phrasering adalah aturan pemenggalan kalimat yang baik dan benar, tetapi tetap mempunyai kesatuan arti dan mudah dimengerti. Phrasering memudahkan kita memberi tandatanda saat dimana kita mengatur nafas dalam bernyanyi. Pengambilan nafas yang tidak pada tempatnya akan mempengaruhi pesan lagu karena tidak sesuai dengan kalimat syair lagu maupun kalimat musiknya. Bernyanyi adalah upaya mengekspresikan lagu yang dibawakan supaya dapat dinikmati oleh orang lain, dengan sebaik-baiknya. Phrasering dapat terbentuk jika kita bernyanyi dengan baik dan aturan pemenggalan kalimatnya mudah dimengerti.

\subsubsection{Ekspresi}

Menurut Soewito (1996: 23), ekspresi adalah cara yang dilakukan penyanyi untuk membawakan lagu dengan baik dari suatu ciptaan sesuai dengan jiwa lagu tersebut. Misalnya sedih, gembira, semangat dan lain-lain, sedangkan menurut Jamalus (1988: 38), ekspresi dalam musik ialah ungkapan pikiran dan perasaan yang mencakup semua nuansa dari tempo, dinamik, dan warna suara dari 
unsur-unsur pokok musik, dalam pengelompokkan frase yang diwujudkan oleh seniman musik/penyanyi, dan disampaikan pada pendengarnya.

Dari pendapat di atas, dapat disimpulkan bahwa ekspresi adalah sesuatu yang bersifat menyatakan perasaan yang mencakup semua nuansa dari dinamik, tempo atau kecepatan musik dan warna suara yang disampaikan pada pendengarnya.

Selain kelima teknik vokal di atas, sikap tubuh adalah salah satu unsur yang harus diperhatikan baik dalam latihan maupun pada saat kita sedang tampil di panggung. Sikap tubuh sangat berpengaruh pada sirkulasi nafas. Sikap ini harus dilatih, baik sikap duduk maupun sikap berdiri. Menurut Widyastuti (2007: 4), sikap tubuh yang baik pada saat bernyanyi adalah cara berdiri atau duduk dalam posisi yang benar, sehingga memberikan keleluasaan pada proses pernapasan dan akan mempengaruhi kualitas suara yang dihasilkan. Sedangkan menurut Soewito (1996:11) : "Sikap tubuh dalam membawakan suatu lagu, dapat dilakukan dengan cara berdiri dan duduk. (1) Berdiri, berdiri tegak dalam keadaan santai, tidak kaku dan tegang. Keberatan kedua tangan tidak menjadi beban atau mengganggu rongga dada. (2) Duduk, duduk dengan senang, bebas, tidak membungkuk atau condong ke belakang".

Berdasarkan pendapat di atas, maka dapat disimpulkan bahwa sikap tubuh merupakan unsur terpenting dalam benyanyi yang dapat dilakukan dengan cara berdiri dan duduk dalam posisi yang benar (santai, tidak kaku dan tegang), dilatih secara terus menerus, sehingga menghasilkan kualitas suara yang baik. 


\subsubsection{Peran}

Peran merupakan serangkaian perilaku yang diharapkan pada seseorang sesuai dengan posisi sosial yang diberikan baik secara formal maupun informal (Friedman, 1992: 286). Peran didasarkan pada ketentuan dan harapan yang menerangkan bahwa pada situasi tertentu, apa yang harus dilakukan individuindividu agar dapat memenuhi harapan-harapan mereka sendiri atau harapan orang lain. Poerwadarminta (1976: 667) menyatakan bahwa, peran merupakan turut serta, ikut partisipasi dalam suatu proses kegiatan tertentu. Komarudin menyatakan suatu konsep tentang peran (1994: 768), sebagai berikut:

“ (1) Bagian dari tujuan utama yang harus dilakukan oleh manajemen, (2) Pola perilaku yang diharapkan dapat menyertai suatu status, (3) Bagian suatu fungsi seseorang dalam kelompok atau pranata, (4) Fungsi yang diharapkan dari seseorang atau karakteristik yang apa adanya, (5) Fungsi setiap variabel dalam hubungan sebab akibat."

Berdasarkan beberapa pendapat tersebut dapat disimpulkan bahwa peran adalah serangkaian perilaku yang diharapkan pada situasi tertentu dan ikut berpartisipasi baik secara individu maupun kelompok dalam suatu kegiatan atau peristiwa. Peran yang dimaksud dalam penelitian ini adalah bagaimana partisipasi Pemandu Nyanyian Jemaat dalam mempersiapkan diri dan materi, baik secara individu maupun kelompok.

\subsubsection{Pemandu Nyanyian Jemaat}

Gereja-gereja di Indonesia mengenal beberapa istilah untuk orang yang memimpin nyanyian jemaat, seperti Pemandu Nyanyian Jemaat, song leader, singer, dirigen jemaat dan sebagainya. Istilah-istilah ini sebenarnya menggambarkan bagian-bagian tugas dari procantor dan cantoria, yaitu 
menolong umat untuk memberikan yang terbaik dalam bernyanyi (Tim Badan Pekerja Majelis Sinode Gereja Kristen Indonesia: 2012).

\subsubsection{Procantor}

Tim Badan Pekerja Majelis Sinode Gereja Kristen Indonesia BPMS GKI (2012) menyatakan bahwa Procantor adalah orang yang memiliki kemampuan untuk memimpin nyanyian jemaat dengan lengkap di dalam ibadah (2012). Kemampuan memimpin jemaat disebut dengan Cantorship. Menurut Tim BPMS GKI (2012) seorang procantor harus mampu memimpin kelompok kecil, besar, muda, tua, mulai dari ibadah anak sampai lansia, dengan atau tanpa paduan suara dan instrumen.

Menurut Simanjuntak (2013:34), seorang procantor harus memiliki kriteria sebagai berikut : (1) Memiliki kehidupan rohani yang baik (tercermin dalam kehidupan sehari-hari) (2) Memiliki kemampuan dan pengetahuan yang luas mengenai pujian dan teknik memimpin pujian serta hal lain yang berkaitan (3) Menguasai teknik-teknik bernyanyi, conducting serta memiliki kriteria cantorship (4) Memiliki wawasan terhadap sejarah musik dan interpretasi sesuai dengan periode musik (5) Menguasai teknik-teknik iringan serta paham dengan gaya/style musik (6) Menguasai nyanyian jemaat dari berbagai sumber Mempunyai pengetahuan tentang liturgi.

\subsubsection{Cantoria}

Simanjuntak (2013: 12) menyatakan bahwa, cantoria adalah sekelompok penyanyi (yang bisa saja di dalamnya terdapat solis) yang tugasnya mendukung pelayan pemimpin pujian (procantor) dengan menyanyikan nyanyian sesuai 
dengan tugas yang sudah ditetapkan. Lebih lanjut Simanjuntak (2013: 25) menyatakan bahwa tugas Procantor dan Cantoria antara lain : (1) Menyanyikan lagu bersama jemaat dengan cara yang baik dan benar (2) Memperkenalkan lagulagu baru kepada jemaat dengan memberikan contoh (3) Mengajarkan lagu tersebut kepada jemaat (4) Memperbaiki cara menyanyikan lagu yang salah, secara langsung atau tidak (jika ternyata lagu tersebut sudah salah dinyanyikan selama ini) (5) Secara bergantian dapat menyanyikan satu lagu "utuh" dengan jemaat

Procantor bisa berfungsi sebagai cantor, yaitu sebagai penyanyi utama yang menyanyikan bagian khusus dalam liturgi. Meskipun sebagai penyanyi utama, suaranya tetap tidak boleh mendominasi atau mengalahkan suara umat. Prier dan Widyawan (2011: 45) menyatakan bahwa, dalam beribadat sesungguhnya suara manusia ditempatkan lebih tinggi derajatnya dari permainan alat musik. Dengan bernyanyi, jemaat akan mendapat manfaat karena mengerti apa yang dinyanyikan.

\subsection{Kerangka Berpikir}

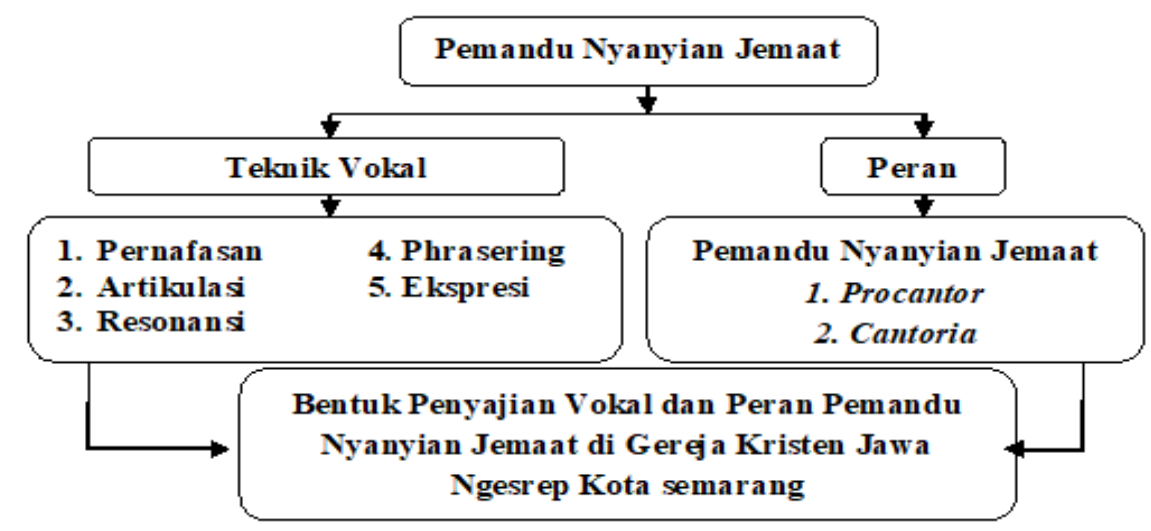

Bagan 1. Kerangka Berpikir

(Sumber: Bella Monica Paula, 17 Juli 2017) 
Keterangan :

Berdasarkan bagan kerangka berpikir, pokok bahasan utama dalam Pemandu Nyanyian Jemaat adalah bagaimana peran yang dilakukan Pemandu Nyanyian Jemaat yang akan diteliti dari sudut bentuk teknik vokalnya. Adapun yang menjadi elemen-elemen dalam teknik vokal meliputi: Pernafasan, Artikulasi, Resonansi, Phrasering dan Ekspresi. Pemandu Jemaat dilihat dari jenisnya terdiri dari Procantor dan Cantoria. Berdasarkan posisi kedua jenis jemaat tersebut adalah sebagai pemimpin dan pengikut dalam bernyanyi. Setelah mendeskripsikan Teknik vokal dan peran jemaat, peneliti akan mengurai dan membahas tentang kelangsungan dari beberapa kegiatan yang telah dilakukan jemaat gereja terutama untuk PNJ di GKJ Ngesrep. Keseluruhan aspek-aspek tersebut disatukan sehingga menciptakan sebuah keutuhan dalam "Teknik Vokal dan Peran Pemandu Nyanyian Jemaat di Gereja Kristen Jawa Ngesrep Kota Semarang”. 


\section{BAB III}

\section{METODE PENELITIAN}

\subsection{Pendekatan Penelitian}

Pendekatan Penelitian ini menggunakan metode penelitian kualitatif. Penelitian kualitatif adalah penelitian yang bersifat deskripsi, tidak menggunakan angka-angka, dan mendeskripsikan berupa ucapan, tulisan dan pengamatan. Adapun permasalahan yang dikaji yaitu tentang Bentuk Penyajian Vokal dan Peran Pemandu Nyanyian Jemaat di GKJ Ngesrep, menggunakan penelitian deskriptif kualitatif. Menurut Nawawi (1991: 63), penelitian deskriptif dapat diartikan sebagai :"prosedur, pemecahan masalah yang diselidiki dengan menggambarkan/melukiskan keadaan subyek/obyek penelitian (seseorang, lembaga, masyarakat dan lain-lain) pada saat sekarang berdasarkan fakta-fakta yang tampak atau sebagaimana adanya”.

Penelitian ini peneliti melakukan wawancara langsung dengan para informan guna memperoleh gambaran berupa pendapat dan pemahaman tentang teknik vokal dan peran Pemandu Nyanyian Jemaat di GKJ Ngesrep. Penelitian deskriptif kualitatif merupakan prosedur untuk memecahkan masalah. Peneliti melihat dan memaparkan dengan rinci tentang Teknik Vokal dan Peran Pemandu Nyanyian Jemaat di GKJ Ngesrep. 


\subsection{Lokasi dan Sasaran Penelitian}

Adapun Penelitian ini akan dilakukan di Gereja Kristen Jawa (GKJ) Ngesrep, Jawa Tengah. Peneliti memilih lokasi ini dengan alasan GKJ Ngesrep merupakan gereja induk di wilayah Ngesrep yang saat ini sedang melakukan pembenahan di bidang musik ibadah terutama pianis/organis dan Pemandu Nyanyian Jemaat. Dalam penelitian ini peniliti hanya fokus pada Bentuk Penyajian Vokal dan Peran Pemandu Nyanyian Jemaat dari persiapan latihan hingga ibadah hari minggu. Penelitian ini dilaksanakan pada bulan JuniSeptember 2017

Fokus dalam penelitian ini adalah bentuk penyajian vokal dalam nyanyian peribadatan di GKJ Ngesrep dan peran Pemandu Nyanyian Jemaat pada proses peribadatan di GKJ Ngersep, dan yang menjadi sasaran dalam penelitian ini adalah Pemandu Nyanyian Jemaat GKJ Ngesrep dan masyarakat yang masih aktif, artinya sebagai pencipta dan penyaji seni, pelaku-pelaku seni, pemerintah setempat, dan orang-orang yang memiliki pengetahuan tentang bentuk penyajian Vokal, nyanyian dan peran Pemandu Nyanyian Jemaat pada proses peribadatan di GKJ Ngesrep.

\subsection{Jenis Data Penelitian}

Jenis data dalam penelitian ini berupa data-data kualitatif, yaitu data-data yang berupa kata-kata, bukan dalam bentuk angka. Data kualitatif diperoleh dari berbagai teknik pengumpulan data yaitu wawancara, hasil observasi, analisis dokumen. Penelitian ini dilakukan untuk memperoleh beberapa data antara lain, 
materi nyanyian ibadah atau partitur nyanyian dan liturgi. Selain itu, data yang diperlukan adalah hasil rekaman berupa audio dan video. Data berupa partitur digunakan untuk mengecek data dari hasil rekaman.

\subsection{Teknik Pengumpulan Data}

Tanpa mengetahui teknik pengumpulan data, peniliti tidak akan mendapatkan data yang memenuhi standar data yang ditetapkan (Sugiyono, 2010: 308). Teknik pengumpulan data pada penelitian ini menggunakan teknik-teknik observasi (pengamatan langsung), wawancara dan dokumentasi yang dilakukan dengan mengacu pada pedoman yang telah dipersiapkan terlebih dahulu dan dikembangkan pada saat pelaksanaannya.

\subsubsection{Observasi}

Observasi kualitatif merupakan observasi yang di dalamnya peneliti langsung turun ke lapangan untuk mengamati perilaku dan aktivitas individuindividu di lokasi penelitian (Creswell, 2010: 267). Metode ini dilakukan secara sistematis dengan mengamati langsung persiapan-persiapan yang dilakukan para pemusik dan Pemandu Nyanyian Jemaat guna mendapatkan data yang akurat tentang Teknik Vokal dan Peran Pemandu Nyanyian Jemaat di GKJ Ngesrep. Peneliti melakukan observasi di dua lokasi, yaitu gedung gereja (tempat pelaksanaan latihan dan ibadah dan kantor gereja. Peneiliti turun ke lapangan sebagai partisipan dengan tetap menampakkan diri sebagai observer. Dengan demikian, peneliti dapat melakukan pengamatan terhadap objek yang diangkat yaitu teknik vokal dan peran Pemandu nyanyn jemaat di GKJ Ngesrep dan 
melakukan perekaman ketika ada informasi yang berkaitan dengan permasalahan yang ada.

\subsubsection{Wawancara}

Wawancara merupakan teknik pengumpulan data dengan cara bertanya langsung kepada narasumber dengan menggunakan pedoman yang telah disiapkan. Penelitian ini menggunakan wawancara semiterstruktur. "Jenis wawancara ini sudah termasuk dalam kategori indepht interview, di mana dalam pelaksanaanya lebih bebas bila dibandingkan dengan wawancara terstruktur" (Sugiyono, 2010: 320). Metode wawancara ini digunakan peneliti untuk memperoleh data tentang Bentuk Penyajian Vokal dan Peran Pemandu Nyanyian Jemaat di GKJ Ngesrep secara akurat dan dapat dipertanggung jawabkan.

Narasumber dalam penelitian ini antara lain Pendeta, majelis, praktisi musik gereja, komisi seni budaya dan pelayan ibadah (pemusik dan Pemandu Nyanyian Jemaat). Wawancara dengan seorang narasumber berlangsung selama \pm 60 -120 menit, dilaksanakan di gedung GKJ Ngesrep pada tanggal 10, 16, 17, 24 dan 25 desember 2017 pada saat latihan dan selesai ibadah minggu. Peneliti membuat pertanyaan dan materi apa saja yang akan ditanyakan atau yang akan dicari peneliti pada narasumber, peneliti bertatap muka langsung dengan narasumber dan pertemuan ini direkam menggunakan fasilitas audio recorder dari handphone serta software nuendo 4 pada laptop dan juga menggunakan kamera DSLR untuk merekam wawancara berupa video. Tujuan dari wawancara ini adalah untuk menemukan permasalahan secara lebih terbuka, di mana pihak yang diajak wawancara diminta pendapat dan ide-idenya. 


\subsubsection{Studi Dokumen}

Dokumen merupakan catatan peristiwa yang sudah berlalu (Sugiyono 2010:329). Lebih lanjut Sugiyono (2010:329) menyatakan bahwa, studi dokumen merupakan pelengkap dari penggunaan metode observasi dan wawancara dalam penelitian kualitatif. Walaupun kata-kata dalam penelitian kualitatif merupakan sumber data utama, akan tetapi dalam konteks penelitian ini memerlukan dokumentasi. Dokumentasi yang ada berupa foto-foto dan video pada saat pemusik dan Pemandu Nyanyian Jemaat berlatih dan pada saat ibadah berlangsung. Dokumentasi yang lain berupa transkrip hasil wawancara dengan ahli.

\subsection{Teknik Penentuan Keabsahan Data}

Keabsahan data dalam penelitian ini menentukan keabsahan (validity) dan keandalan (reliability) penelitian, atau secara keseluruhan dapat menentukan kepercayaannya (trustworthiness) (Rohidi 2011: 218). Untuk menjaga kepercayaan, penelitian ini menguakan teknik (1) triangulasi data, (2) triangulasi sumber, (3) triangulasi metode artinya proses pengujian kepercayaan dapat dilakukan dengan cara memeriksa data yang telah diperoleh melalui berbagai sumber yang diperoleh selanjutnya dideskripsikan, dikategorikan, dan diananlisis sehingga menghasilkan suatu kesimpulan. Teknik ini dilakukan dengan cara atau langkah: (1) membandingkan data hasil pengamatan dan wawancara, (2) membandingkan apa yang dikatakan informan di depan umum dengan di depan peneliti, (3) membandingkan apa yang dilakukan informan pada saat penelitian 
dan saat sepanjang waktu, (4) membandingkan perspektif dan keadaan orang dengan tanggapan orang lain, dan (5) membandingkn hasil wawancara dan dokumen yang ada yaitu sesuai dengan objek yang diangkat. Sejalan hal tersebut Moleong (2004 : 173) mengatakan bahwa ada empat kriteria yang digunakan salah satunya adalah derajat kepercayaan pada dasarnya ini merupakan hal mengantikan konsep palidasi internal dari non kualitatif, yaitu yang berkaitan dengan persoalan seberapa jauh kebenaran hasil penelitian dapat dipercaya. Yang pertama, peneliti pengamatan secara terus menerus dan memperhatikan sesuatu secara lebih cermat, terinci dan mendalam. Peneliti mebedakan dan mengumpulkan hal-hal yang bermakna untuk memahami gejala-gejala tertentu. Kedua, menunjukan derajat kepercayaan hasil penemuan dengan jalan pembuktian oleh peneliti pada kenyataan ganda yang diteliti

\subsection{Teknik Analisis Data}

Proses analisis data dilakukan dengan sistematik dimulai dengan pengumpulan data, mereduksi, mengklasifikasikan, mendeskripsikan, dan menginterpretasikan semua informasi yang telah terkumpul. (Sugiyono, 1992 : 16) mengemukakan bahwa teknik analisis terdiri dari tiga alur kegiatan yang terjadi secara bersamaan yaitu reduksi data, penyajian data, dan penarikan kesimpulan/verifikasi.

\subsubsection{Reduksi Data}

Reduksi data merupakan struktur atau peralatan yang memungkinkan kita untuk memilah, memilih, memusatkan perhatian, mengatur, dan 
menyederhanakan data. Pada penelitian ini, reduksi data digunakan untuk merangkum data yang diperoleh dari lapangan.

\subsubsection{Penyajian Data}

Penyajian data merupakan susunan informasi yang dapat memungkinkan kesimpulan dapat ditarik. Dalam penelitian ini akan disajikan data secara lengkap, baik data yang diperoleh dari hasil observasi, dokumen, maupun wawancara, kemudian dianalisis antara kategori dan permasalahan yang ada guna mendapat sajian yang jelas dan sistematis, sehingga kegiatan mengumpulkan data dapat tersaji dengan baik.

\subsubsection{Verifikasi/Penarikan Kesimpulan}

Verifikasi merupakan langkah terakhir dari analisis data setelah direduksi dan dideskriptifkan dalam bentuk sajian data. Sajian data diinterpretasi dalam setiap bab atau bagian untuk mendapatkan susunan dari kesimpulan akhir yang sistematis.

Dalam proses analisis data, penarikan kesimpulan tidak hanya dilakukan pada akhir pengumpulan data. Kesimpulan dapat dirumuskan sebelumnya. Sejak awal kesimpulan kesimpulan yang telah diambil juga diverifikasi selama penelitian berlangsung. Verifikasi dapat dilakukan dalam waktu singkat ketika pemikiran melintas pada pikiran peneliti, dan dapat juga dilakukan dalam waktu yang lama, karena peneliti melakukan peninjauan kembali terhadap data yang telah dikumpulkan. 


\section{BAB IV}

\section{HASIL PENELITIAN DAN PEMBAHASAN}

Secara urut hasil penelitian dan pembahasan ini akan dimulai dari gambaran umum lokasi penelitian, hasil penelitian dan pembahasan yang berhubungan dengan usaha untuk menjawab permasalahan bagaimanakah bentuk penyajian vokal dalam nyanyian peribadatan di GKJ Ngesrep dan bagaimanakah peran Pemandu Nyanyian Jemaat pada proses peribadatan di GKJ Ngersep Kota Semarang.

\subsection{Gambaran Umum Lokasi Penelitian}

\subsubsection{Letak Geografis Kota Semarang}

Luas dan batas wilayah, Kota Semarang dengan luas wilayah 373, 70 Km2. Secara administratif, Kota Semarang terbagi menjadi 16 Kecamatan dan 177 Kelurahan. Dari 16 Kecamatan yang ada, terdapat 2 Kecamatan yang mempunyai wilayah terluas yaitu Kecamatan Mijen, dengan luas wilayah 57,55 Km2 dan Kecamatan Gunungpati, dengan luas wilayah 54,11 Km2. Kedua Kecamatan tersebut terletak di bagian selatan yang merupakan wilayah perbukitan yang sebagian besar wilayahnya masih memiliki potensi pertanian dan perkebunan, sedangkan kecamatan yang mempunyai luas terkecil adalah Kecamatan Semarang Selatan, dengan luas wilayah 5,93 Km2 diikuti oleh Kecamatan Semarang Tengah, dengan luas wilayah 6,14 Km2 . Wilayah Administrasi Kota Semarang (Km2) 


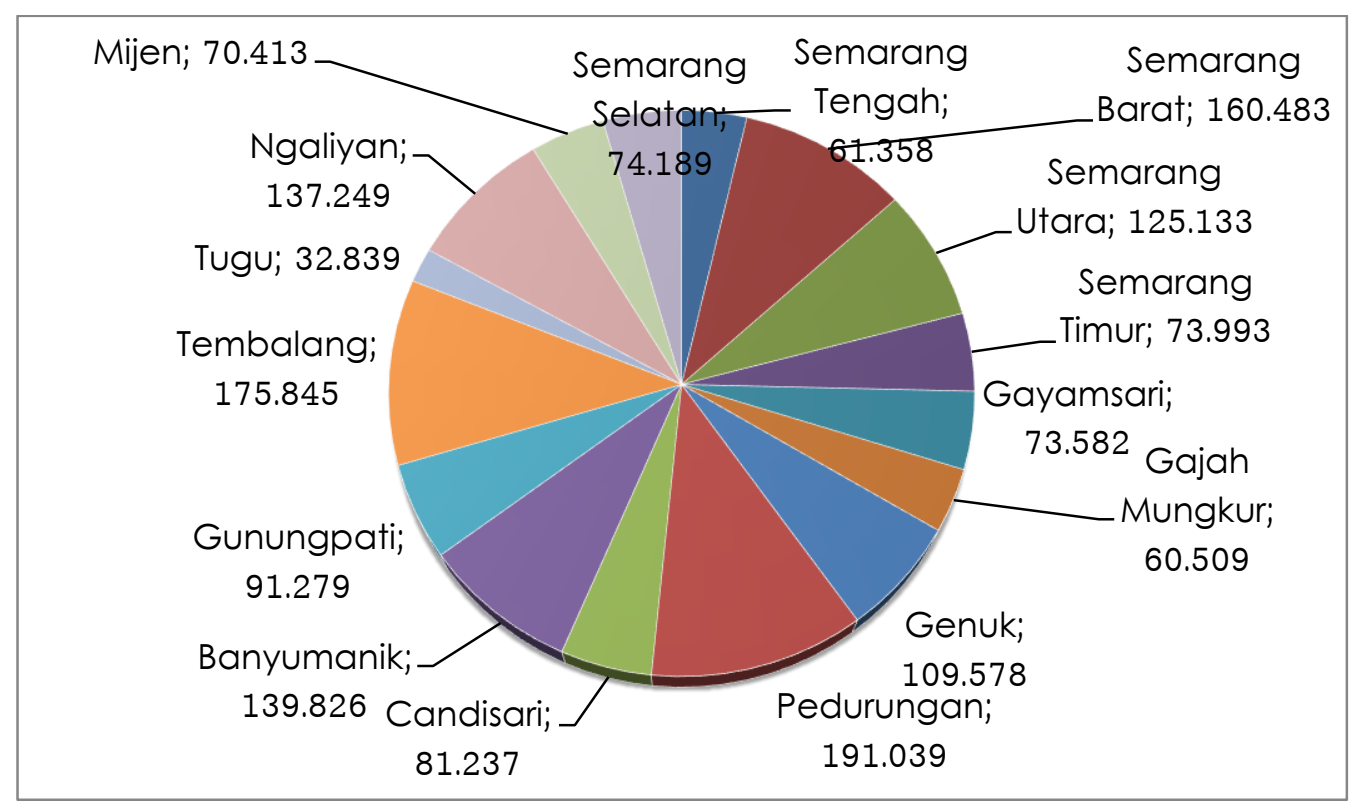

Gambar 6. Diagram Luas Wilayah Kecamatan di Kota Semarang (Sumber: Kota Semarang dalam Angka 2017, BPS (data diolah))

Letak dan kondisi geografis, Kota Semarang memiliki posisi astronomi di antara garis $6050^{\prime}-7010^{\prime}$ Lintang Selatan dan garis $109035^{\prime}-110050$ ' Bujur Timur. Kota Semarang memiliki posisi geostrategis karena berada pada jalur lalu lintas ekonomi pulau Jawa, dan merupakan koridor pembangunan Jawa Tengah yang terdiri dari empat simpul pintu gerbang yakni koridor pantai Utara; koridor Selatan ke arah kota-kota dinamis seperti Kabupaten Magelang, Surakarta yang dikenal dengan koridor Merapi-Merbabu, koridor Timur ke arah Kabupaten Demak/Grobogan; dan Barat menuju Kabupaten Kendal. Dalam perkembangan, pertumbuhan Jawa Tengah, Semarang sangat berperan terutama dengan adanya pelabuhan, jaringan transport darat (jalur kereta api dan jalan) serta transport udara yang merupakan potensi bagi simpul transportasi Regional Jawa Tengah dan Kota Transit Regional Jawa Tengah. Posisi lain yang tak kalah pentingnya adalah kekuatan hubungan dengan luar Jawa, secara langsung sebagai pusat 
wilayah nasional bagian tengah. Kota Semarang untuk memepertegas deskripsi di atas peneliti menambahkan gambar peta kota semarang.

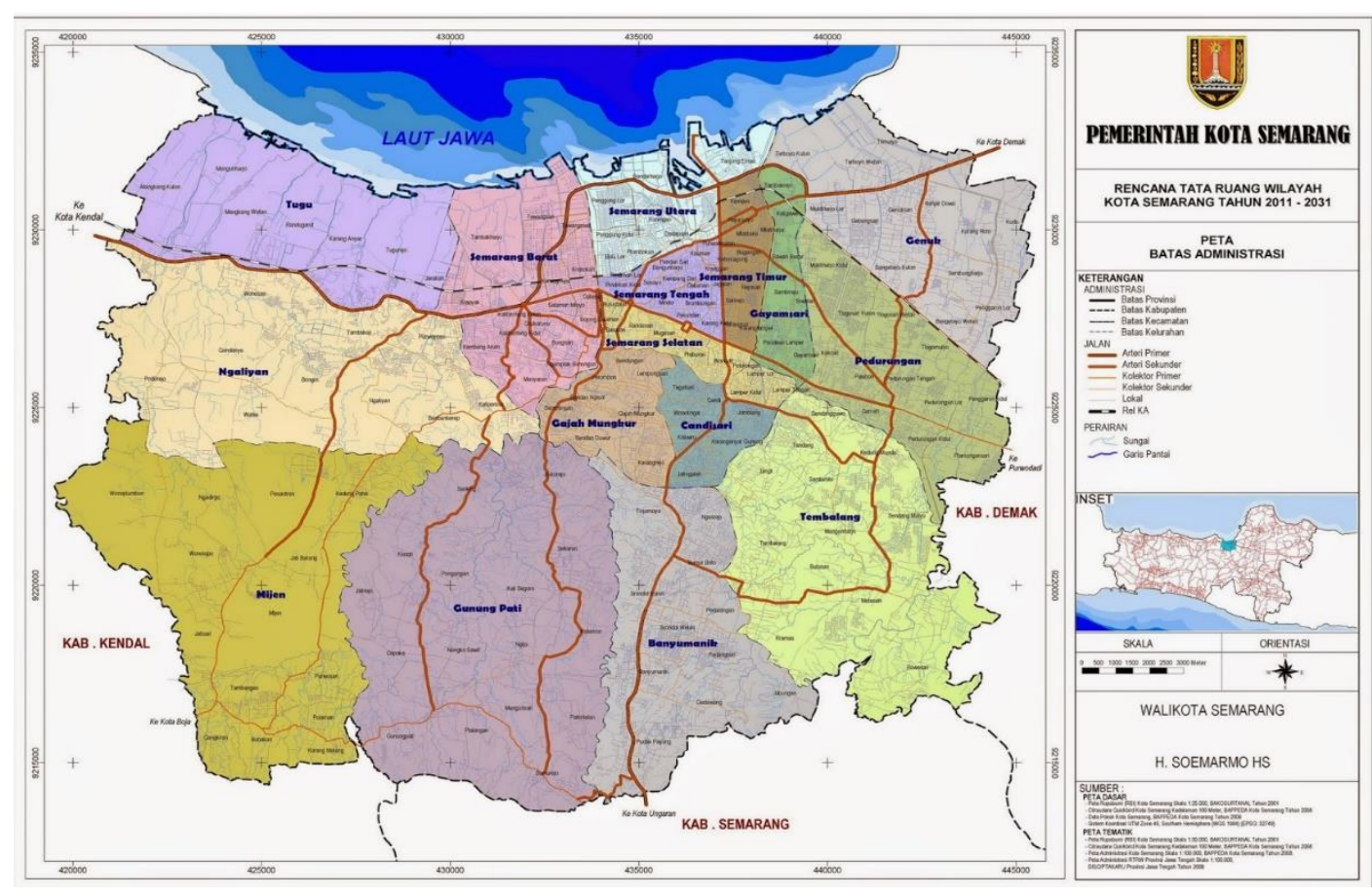

Gambar 7. Peta Kota Semarang

(Sumber : Google, 17 Desember 2017)

Secara topografis Kota Semarang terdiri dari daerah perbukitan, dataran rendah dan daerah pantai, dengan demikian topografi Kota Semarang menunjukkan adanya berbagai kemiringan dan tonjolan. Daerah pantai 65,22\% wilayahnya adalah dataran dengan kemiringan $25 \%$ dan $37,78 \%$ merupakan daerah perbukitan dengan kemiringan 15-40\%. Kondisi lereng tanah Kota Semarang dibagi menjadi 4 jenis kelerengan yaitu lereng I (0-2\%) meliputi Kecamatan Genuk, Pedurungan, Gayamsari, Semarang Timur, Semarang Utara dan Tugu, serta sebagian wilayah Kecamatan Tembalang, Banyumanik dan Mijen. Lereng II (2-5\%) yang meliputi Kecamatan Semarang Barat, Semarang Selatan, Candisari, Gajahmungkur, Gunungpati dan Ngaliyan, lereng III (15-40\%) meliputi 
wilayah di sekitar Kaligarang dan Kali Kreo (Kecamatan Gunungpati), sebagian wilayah kecamatan Mijen (daerah Wonoplumbon) dan sebagian wilayah Kecamatan Banyumanik, serta Kecamatan Candisari. Sedangkan lereng IV (> $50 \%$ ) meliputi sebagian wilayah Kecamatan Banyumanik (sebelah tenggara), dan sebagian wilayah Kecamatan Gunung pati, terutama disekitar Kali Garang dan Kali Kripik.

Kota Bawah yang sebagian besar tanahnya terdiri dari pasir dan lempung. Pemanfaatan lahan lebih banyak digunakan untuk jalan, permukiman atau perumahan, bangunan, halaman, kawasan industri, tambak, empang dan persawahan. Kota Bawah sebagai pusat kegiatan pemerintahan, perdagangan, perindustrian, pendidikan dan kebudayaan, angkutan atau transportasi dan perikanan. Berbeda dengan daerah perbukitan atau Kota Atas yang struktur geologinya sebagian besar terdiri dari batuan beku. Wilayah Kota Semarang berada pada ketinggian antara 0 sampai dengan 348,00 meter dpl (di atas permukaan air laut). Secara topografi terdiri atas daerah pantai, dataran rendah dan perbukitan, sehingga memiliki wilayah yang disebut sebagai kota bawah dan kota atas. Pada daerah perbukitan mempunyai ketinggian 90,56 - 348 mdpl yang diwakili oleh titik tinggi yang berlokasi di Jatingaleh dan Gombel, Semarang Selatan, Tugu, Mijen, dan Gunungpati, dan di dataran rendah mempunyai ketinggian 0,75 mdpl.

\subsubsection{Letak dan Kondisi Geografis Gereja Kristen Jawa Ngesrep Semarang}

Gereja Kristen Jawa Ngesrep (GKJ Ngesrep) yang termasuk ke dalam lingkup GKJ klasis Semarang Selatan. Lokasi GKJ Ngesrep bertempat di jalan 
Ngesrep Barat VI/1, Kelurahan Srondol Kulon, Kecamatan Banyumanik, Kota Semarang, Jawa Tengah 50263, Indonesia. Adapun untuk mempertegas deskripsi di atas peneliti menambahkan gambar peta lokasi penelitian yaitu GKJ Ngesrep

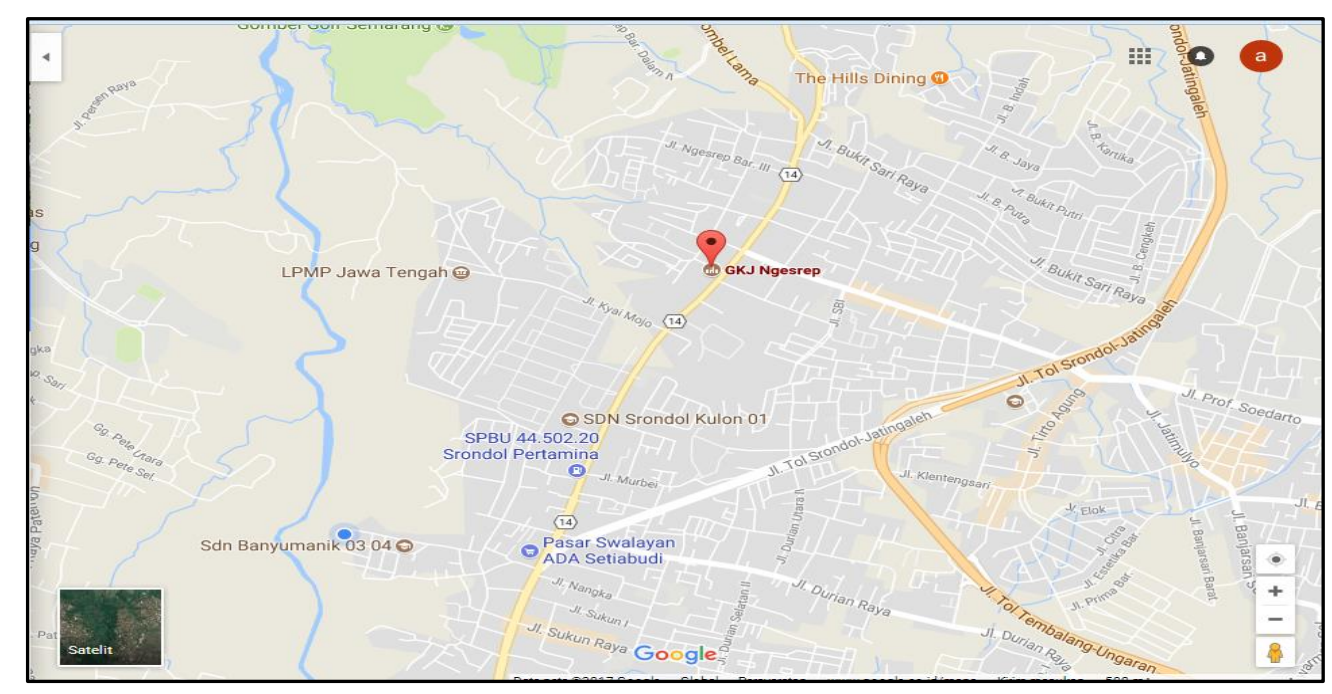

Gambar 8. Letak Gereja Kristen Jawa Ngesrep Semarang Pada Peta (Sumber: Google Map, 14 Agustus 2017)

Lokasi Gereja Kristen Jawa Ngesrep cukup strategis karena berada di tengah kota Semarang kecamatan banyumanik, Lokasi yang strategis dikarenakan Gereja Kristen Jawa Ngesrep berdekatan dengan kantor pelayanan publik atau masyarakat, antara lain kantor SAMSAT Banyumanik, Kodim, sekolah seperti SD SEMESTA, SD Srondol Kulon 01 dan 02, SD Bukit Aksara, SMP Negeri 27, Perumahan Griya Bukit Mas, Perumahan Bukit Sari, Perumahan Nirwana Hill, dekat dengan beberapa hotel dan penginapan ternama, serta Universitas Negeri Diponegoro yang merupakan universitas negeri ternama di Jawa Tengah. Hal tersebut yang menyebabkan GKJ Ngesrep sangat mudah untuk diakses bagi jemaatnya yang ingin beribadah di GKJ Ngesrep dan hal tersebut yang 
memudahkan peneliti untuk mengakses lokasi penelitian yang berada di kecamatan Banyumanik tepatnya JL. Ngesrep Barat VI/1 Semarang.

\subsubsection{Status Kegerejaan}

Gereja Kristen Jawa (GKJ) Ngesrep Dewasa hari kamis tanggal 21 Mei 1999 yang didewasakan oleh GKJ Ungaran Selaku gereja Induknya atas persetujuan sidang Gereja-gereja Kristen Jawa Klasis Semarang Timur XIX dan restu dari Sinode GKJ. Adapun ketenagaan di dalam GKJ adalah Pendeta oleh Bapak Iskak Dodie Irawan, S.Si., dengan tenaga administrasi Ibu Agustin Kharolina Hadi dan yang terakhir Pekarya/Koster Bapak Timotius Trulino, dari pendeskripsian di atas dapat disimpulkan bahwa di dalam gereja Kristen Jawa Ngesrep telah berdiri sejak tanggal 21 Mei 1998 dan mempunyai struktur yang kuat dapat dilihat dalam ketenegaan yaitu adanya pendeta,tenaga administrasi, Pekarya koster.

Struktur organisasi Gereja Kristen Jawa (GKJ) Ngesrep Semarang tahun 2017 adalah sebagai berikut ;

Struktur Kemajelisan

Majelis Pelaksana Harian (MPH)

Ketua I

Ketua II

Sekretaris I

Sekertaris II

Bendahara I

Bendahara II
: Penatua Stefanus Sugiman

: Pendeta Iskak Dodie Irawan, S. Si

: Penatua Hindiarno

: Diaken Joko Marwanto

: Penatua Agus Supriyanto

: Diaken Tri Iswanto 
Majelis Koordinator Bidang (KorBid)

Bidang Keesaan

Bidang Pembinaan Warga Gereja (PWG)

Bidang Kesaksian Pelayanan

Majelis Pendamping (Maping)

Majelis Pendamping Tim Liturgika

Majelis Pendamping Tim Multimedia

Majelis Pendamping Komisi Anak
: Pendeta Iskak Dodie Irawan, S. Si

: Penatua Stefanus Sugiman

: Almarhum Penatua Sri Widekso

: Pendeta Iskak Dodie Irawan, S. Si

: Penatua Agus Supriyanto

: Diaken Sugiarti

Majelis Pendamping Komisi Pemuda Remaja: Diaken Thomas Nugrahanto

Majelis Pendamping KWD : Penatua Stefanus Sugiman

Majelis Pendamping Wilayah Banyumanik : Diaken Budiyanto

Majelis Pendamping Wilayah Ngesrep : : Almarhum Penatua Sri Widekso

Majelis Pendamping Wilayah Srondol : Diaken Joko Marwanto

Majelis Pendamping Komisi Pekabaran Injil : Diaken Y.D. Sutoro

Majelis Pendamping Komisi Diakonia $\quad$ : Ddiaken Dwi Purwantiningsih

Majelis Pendamping Komisi Pralenan : : Almarhum Penatua Sri Widekso

Majelis Pendamping Komisi Seni Budaya : Diaken Farida Erawati

Majelis Pendamping Tim Paduan Suara : Penatua Hindiarno

Komisi seni dan budaya di GKJ Ngesrep

Susunan pengurus

Ketua 1

: Maria Denok BA. Dodie irawan

Ketua 11

: Nina Woelan S.

Sekretaris 1

:Indriastuti W. Agus Supriyanto

Sekretaris 11

: Rini Mulatsih

Bendahara

: Nunuk Damayanti Joko M.

Anggota

: Sri Waryanti

: Supriyani 
: Samuel Indah Puji Tri Iswanto

: Ruth Haryanti

: Rian Danis Talarima

: Harry Benjamin M.

\subsubsection{Gedung Gereja}

Gedung gereja GKJ Ngesrep berdiri di atas tanah seluas 24 x 12.20 meter persegi dengan luas bangunan 19 x 12,20 meter persegi serta balkon seluas 7 x 5 meter persegi. Kondisi gedung gereja layak pakai dengan kapasitas 200 orang jemaat. Adapun kegiatan gereja atau pelayanan, kantor dibuka pada setiap hari kerja, yaitu Senin sampai Kamis pada jam 08.00- 15.00 WIB dan Jumat jam 08.00-12.00 WIB, kemudian hari Sabtu Jam 08.00-13.00 WIB Berdasarkan pendeskripsian di atas dapat ditarik kesimpulan bahwa Gedung Gereja Kristen Jawa Ngesrep dengan kondisi yang baik dan kapasitasnya cukup memadai karena dapat dilihat dari kapasitasnya yang mencapai 200 orang jemaat dan dilihat dari kegiatan kantor pelayanan yang sangat baik dengan jam oprasional dari hari senin sampai sabtu dibuka.

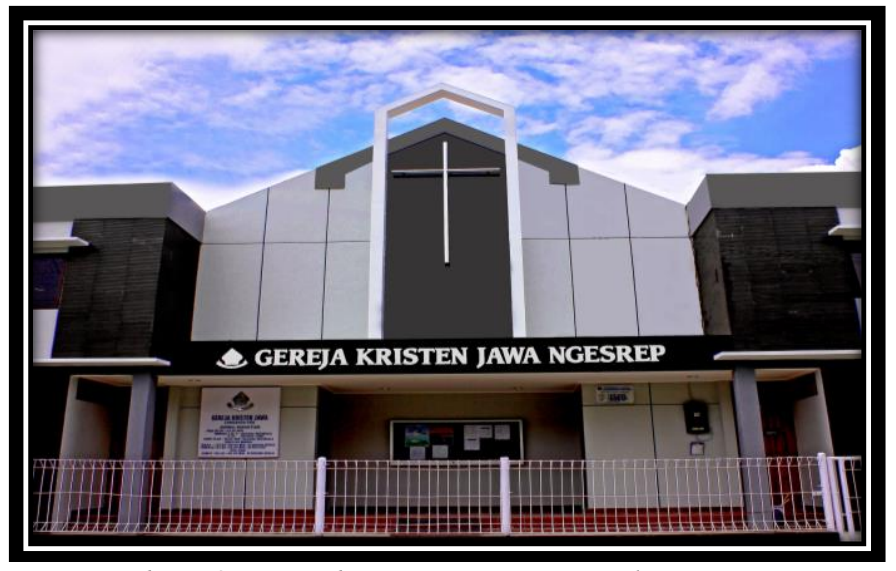

Gambar 9. Gambar Greja Nampak Depan

(Sumber : Bella Monica Paula, 2017) 


\subsubsection{Kegiatan Kegerejaan}

Adapun kegiatan kegerejaan di GKJ Ngesrep pada tahun 2016/2017 meliputi (1). Peribadatan reguler yang diadakan setiap hari Minggu dilaksanakan ibadah rutin sesuai jadwal pagi jam 06.00 sampai selesai dan sore pada jam 17.00 sampai selesai (2). Peribadatan khusus meliputi ibadah hari raya gerejawi antara lain Kamis Putih yang diadakan pada bulan Maret, Jumat Agung yang diadakan pada bulan Maret, Paskah yang diadakan pada bulan Maret, kenaikan Tuhan Yesus yang diadakan pada bulan Mei, kemudian Natal yang diadakan pada bulan Desember kemudian Sakramen Perjamuan Kudus, Kebaktian Khusus, Kebaktian Pemakaman, Kebaktian HUT RI, Sakramen Babtis dan, Komposisi Pengkotbah (3). Katekisasi (4). Persekutuan doa (5).Pemahaman Alkitab (6). Sosialisasi 7). Rapat-rapat (8). Pemanggilan Majelis (9). Kunjungan dan Pastoral (10). Kegiatan Internal (11). Kegiatan Keluar, sedangkan jadwal kegiatan jemaat GKJ Ngesrep dalam seminggu meliputi (1). Setiap hari Minggu ibadah dimulai pukul 06.00 WIB dan ibadah sore dimulai pada pukul 17.00 WIB dan untuk minggu ke I, II, dan IV kebaktian minggu dewasa berbahasa Indonesia, menggunakan buku Kidung: Kidung Jemaat, Pelengkap Kidung Jemaat, Nyanyian Kidung Baru. Untuk Minggu ke III kebaktian mingu dewasa berbahasa jawa, menggunakan buku kidung: Kidung Pasamuan Kristen, Kidung Pasamuan Jawi. Setelah kegiatan peribadatan pagi ada kebaktian anak-anak sekolah minggu. (2). Hari Selasa rapat majelis yang dilaksanakan di gedung gereja pada pukul 19.00 WIB (3). Persekutuan doa di masing-masing wilayah (4). Hari Jumat ada persekutuan doa 
pagi yang dilaksanakan di gedung gereja pada pukul 05.00 WIB, dan malam harinya ada latihan paduan suara GKJ Ngesrep pada pukul 19.00 WIB .

\subsubsection{Struktur Peribadatan GKJ Ngesrep}

Adapun contoh tradisi sebelum melakukan ibadah adalah, bahwa suku Lewi mengatur dan membagi tugas masing-masing orang yang terlibat dalam ibadah tersebut, salah satunya perangakat yang harus ada dalam ibadah tersebut yaitu petugas kelompok musik (baca I Tawarikh 6:31-32; I Tawarikh 23: 5; 25: 18). Kelompok musik ini bukan kelompok yang hanya sekedarnya atau seadanya saja, melainkan sebuah kelompok yang mempunyai tanggung jawab dengan sungguh-sungguh melaksanakan tugasnya seperti yang tertulis pada Alkitab, I Tawarikh 25: 7 yang berbunyi, "Jumlah mereka bersama-sama saudara-saudara mereka yang telah dilatih bernyanyi untuk Tuhan mereka sekalian adalah ahli seni ada dua ratus delapan puluh delapan orang' Lembaga Alkitab Indonesia (2000: 480). Sejalan dengan hal tersebut Tim Badan Pekerja Majelis Sinode Gereja Kristen Indonesia (2012: 7) juga menyatakan bahwa Pada masa itu juga disebutkan bahwa suku Lewi ditetapkan sebagai petugas di rumah Tuhan sehingga muncul tradisi yang kuat bahwa ibadah harus dipersiapkan dengan baik agar dapat berjalan dengan hikmat.

Berdasarkan pemaparan di atas dapat ditarik kesimpulan bahwa bentuk struktur peribadatan adalah segala sesuatu yang disajikan atau ditampilkan dari awal sampai akhir untuk dapat dinikmati atau dilihat yang di dalamnya mengandung unsur nilai-nilai keindahan yang disampaikan oleh pencipta kepada penikmat adapun di dalam musik gereja juga terdapat struktur atau perangkat 
dalam ibadah yaitu perangakat yang harus ada dalam ibadah tersebut yaitu petugas kelompok musik yang mempunyai peran penting terhadap berjalannya proses peribadatan.

Sejalan dengan pendapat tersebut di dalam bukunya yang berjudul Buku Kenangan Penahbisan Pendeta GKJ Ngesrep Oleh Simon, PS (2000: 22) adapun susunan atau struktur penyajian di GKJ Ngesrep yang disubut Liturgi kebaktian GKJ Ngesrep, pertama-tama pra ibadah yang di dalamnya ada persiapan ibadah, para pelayan berdoa di ruang konsisturi sebelum masuk ke dalam ruang ibadah, untuk mempertegas hal tersebut peneliti menambahkan foto sebagai berikut:

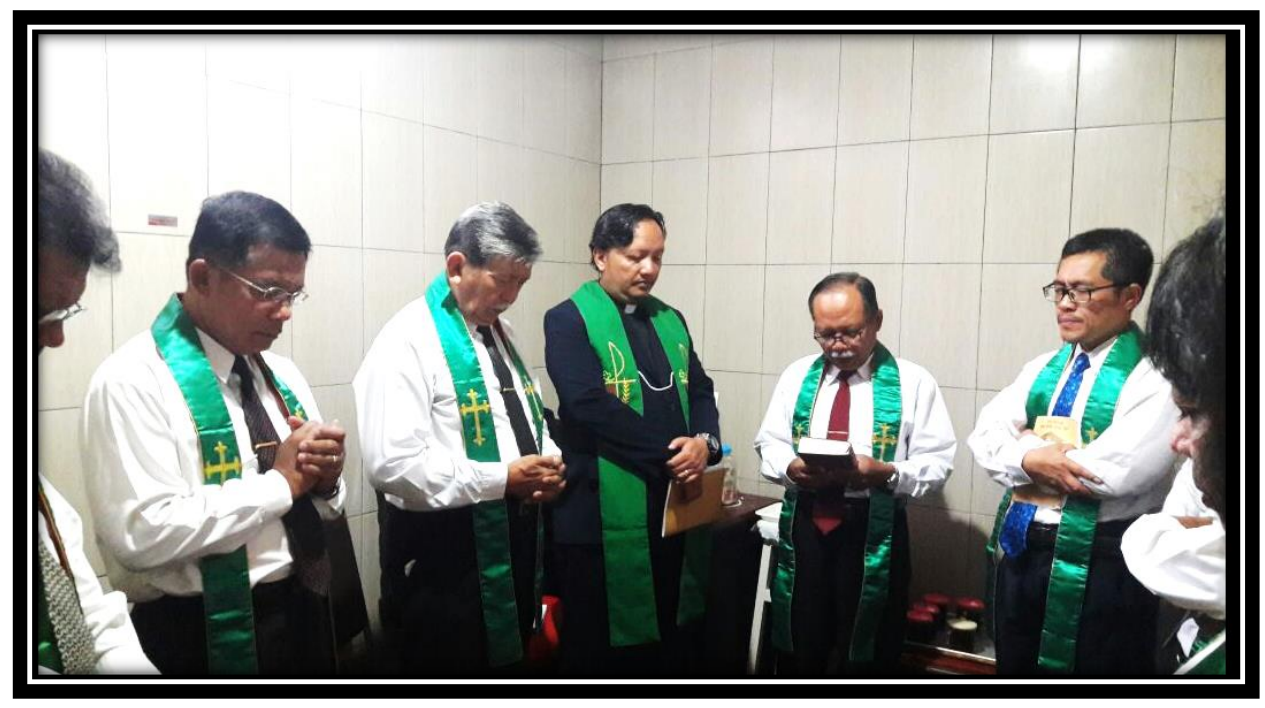

Gambar 10 Para Petugas Sebelum Memulai Peribadatan (sumber Bella Monica Paula 24 Desember 2017)

Sementara itu Pemandu Liturgi membacakan warta gereja. Bel berbunyi 1 kali tanda ibadah dimulai dan pelayan memasuki ruang ibadah bersama pendeta. Kemudian dilanjutkan dengan sapaan awal dengan Pemandu Liturgi mengucapkan "Dengan berdiri mari kita menyiapkan diri kita untuk beribadah secara bersama menyanyikan lagu Kidung Jemaat. 21 ; 1 yang berjudul "Hari 
Minggu, Hari Yang Mulia”. Kemudian setelah selesai menyanyikan lagu pujian, dilanjutkan Pelayan Firman menyampaikan vontum dan salam dengan mengucapkan "Marilah kebaktian ini diawali dengan keyakinan bahwa pertolongan kita adalah dari Allah Bapa yang menjadikan langit dan bumi serta segala isinya dan sekali-kali tidak meninggalkan perbuatan tanganNya. Kiranya damai sejahtera dari Allah Bapa dan dari Yesus Kristus ada pada kita sekalian”.

Disambut jemaat dengan menyanyikan “amin, amin, amin”, kemudian jemaat duduk. Menyanyikan satu lagu pujian dan Pelayan Firman memimpin doa pembukaan. Doa pembukaan yang bertujuan supaya hadirat Tuhan benar-benar hadir di dalam kebaktian. Setelah itu Pelayan Firman mengucapkan hukum kasih “Seperti Bapa telah mengasihi Aku, demikian juga Aku telah mengasihi kamu, tinggalah di dalam kasihMu itu. Jikalau kamu menuruti perintahKu, kamu akan tinggl di dalam KasihKu, seperti Aku menuruti perintah Bapaku dan tinggal di dalam kasihNya. Semua itu Kukatakan kepadamu, supaya sukacitaKu ada di dalam kamu dan sukaitamu menjadi penuh. Inilah perintahKu, yaitu supaya kamu saling mengasihi, seperti Aku telah mengasihi kamu. Tidak ada kasih yang lebih besar daripada kasih seorang yang memberikan nyawanya untuk sahabatsahabatnya. Kamu adalah sahabatKu, jikalau kamu berbuat apa yang Kuperintahkan kepadaMu.” (Yohanes 15 : 9-14). Berikut foto Pelayan Firman memipin doa pembukaan: 


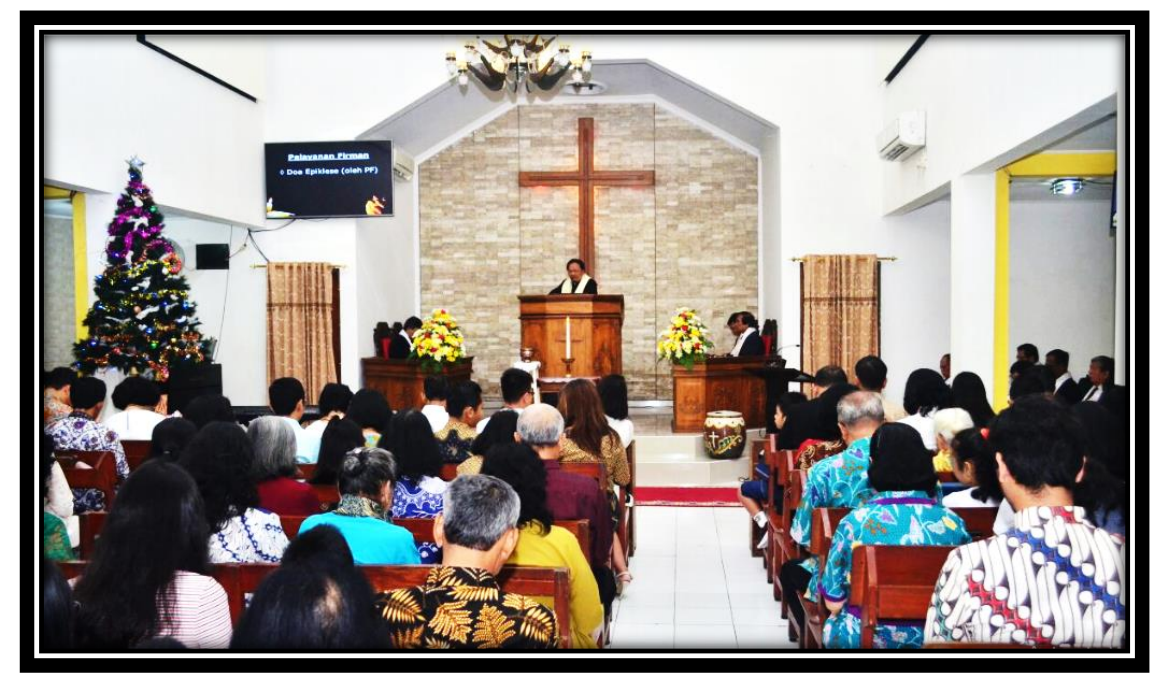

Gambar 11 pendeta memipin doa pembuka kepada para jemaat (sumber Bella Monica Paula 24 Desember 2017)

Setelah Pelayan Firman membacakan hukum kasih, kemudian dilanjutkan dengan pujian penyesalan dan jemaat dianjurkan untuk duduk kembali, kemudian jemaat berdiri ketika dibacakan anugerah Allah dinyatakan, kemudian petunjuk hidup baru dibackan oleh Pelayan Firman yang dibalas oleh jemaat dengan mengucapkaan "syukur kepada Allah" kemudian jemaat bersalaman satu sama lain dan mengucapkan "salam damai". Kemudian dilanjutkan dengan nyanyian kesanggupan yang dinyanyikan oleh Pemandu Nyanyian Jemaat. Setelah itu tata ibadah memasuki pelayanan Firman, kemudian Pelayan Firman berdoa memohon pimpinan roh kudus, setelah membacakan firman Tuhan. Kemudian dilanjutkan khotbah/firman oleh pendeta. Setelah khotbah selesai dilanjutkan dengan saat teduh, dimana jemaat diberi waktu tenang untuk merenungi khotbah yaang baru saja didengar supaya masuk ke dalam hati sanubari jemaat dan dapat menerapkannya di dalam kehidupannya sehari-hari. Setelah itu jemaat dipersilahkan berdiri untuk melanjutkan pembacaan pengakuan iman Rasuli. 
Setelah pengakuan iman Rasuli Pelayan Firman mengajak duduk, Pelayan Firman mengajak jemaat untuk bersatu hati berdoa syafaat, yaitu doa untuk bangsa, negara, para pemimpin ditiap-tiap tingkatan pemerintahan, kota Semarang, masalah dan kesenjangan yang sedang terjadi, pendidikan, keluarga kristen, janda, yatim piatu, orang yang berkekurangan, orang-orang yang sendiri dalam kehidupannya, jemaat yang sedang mengalami pergumulan hidup, dan jemaat yang sedang menderita sakit penyakit. Setelah berdoa syafaat, jemaat memberikan persembahan syukur yang berupa uang dan diiringi dengan pujian Pemandu Nyanyian Jemaat yang sudah ditentukan. Setelah majelis mengedarkan kantong persembahan dan dikumpulkan menjadi satu didepan altar, oleh pendeta memanjatkan doa untuk memberkati persembahan yang jemaat sudah berikan. Kemudian dilanjutkan dengan doa penutup dan doa Bapa Kami (jemaat berdiri).

Setelah itu nanyian pengutusan oleh Pemandu Nyanyian Jemaat, dan dilanjutkan dengan pengutusan dan berkat. Pelayan Firman : Saudara-saudara yang dikasihi Tuhan, sekarang undurlah dari tempat ibadah ini, pergilah dalam damai sejahtera Tuhan dan berlakukanlah firman Allah yang telah kita dengar, serta Berikanlah Injil Kepada Sesama kita. Sekarang terimalah Berkat dari Tuhan, “Tuhan Memberkati dan melindungi kita; Tuhan menyinari kita dengan wajahNya kepada kita dan memberikan kita damai sejahtera, amin", jemaat menyahut dengan berkata Amin. Ditutup dengan Nyanyian Pemandu Nyanyian Jemaat penutup sambil jemaat berdiri setelah selesai jemaat kembali duduk, berdoa secara pribadi sebelum pulang kemudian bersalaman dengan pelayan Tuhan, Majelis dan 
Pendeta (keterangan: PL: Petugas Liturgi, Pelayan Firman: Pelayan Firman, Pemandu Nyanyian Jemaat : Pemandu Nyanyian Jemaat).

Berdasarkan struktur peribadatan di atas hal tersebut juga dipertegas dari kutipan wawancara dengan ketua Komisi Seni Budaya, ibu Maria Denok pada tanggal 10 Desember yang mengatakan bahwa

“.....di dalam struktur penyajian Pemandu
Nyanyian Jemaat proses peribadatan memang
mempunyai strukturnya adalah sebelum memulai ibadah
Pemandu Nyanyian Jemaat berkumpul diruang
Konsisturi untuk berdoa bersama dengan bapak Pendeta
setelah itu kami kembali ke tempat kami bertugas dan
mempersiapkan lagu pertama yang akan dinyanyikan
pada pembukaan ibadah, setelah itu bel berbunyi sekali
baru kami langsung berdiri dan mulai menyanyi lagu
pembukaan....,.

Dari hasil wawancara di atas dapat disimpulkan bahwasanya di dalam proses peribadatan di GKJ Ngesrep mempunyai struktur yang Pertama yaitu berkumpul dalam ruangan yang dinamakan ruang konsisturi untuk berdoa bersama para pelayan sebelum memulai ibadah khususnya bagi Pemandu Nyanyian Jemaat mempersiapkan buku panduan yang berisi puji-pujian Untuk Bernyanyi kemudian setelah proses peribadatan dimulai Pemandu Nyanyian Jemaat Memposisikan diri berdiri di samping kanan mimbar menghadap majelis yang duduk samping kiri mimbar dan mengambil mikrofon sembari menunggu waktunya bernyanyi bagi Pemandu Nyanyian Jemaat GKJ Ngesrep. Untuk melengkapi data di atas peneliti menambahkan hasil dari studi dukumen yaitu berupa materi partitur lagu Pemandu Nyanyian Jemaat Yang dibawakan pada saat peribadatan. 
Sejalan dengan hal tersebut Bentuk nyanyian jemaat dan masing-masing memiliki ciri-ciri masing-masing. Salah satunya adalah hymn. Menurut Tim Badan Pekerja Majelis Sinode Gereja Kristen Indonesia BPMS GKI (2012: 16) bahwa hymn adalah nyanyian yang berisi pujian kepada Tuhan. Untuk itu pemahaman mengenai hymnology amat penting, hymnology adalah ilmu yang mempelajari musik gereja yang digunakan dan dinyanyikan oleh umat Kristiani dalam ibadah.

\subsection{Teknik Vokal dalam Pemandu Nyanyian Jemaat GKJ Ngesrep}

Menurut Soewito (1996: 11), ada beberapa unsur yang harus diperhatikan dalam bernyanyi, unsur-unsur tersebut terdiri dari sikap tubuh yang baik, cara bernafas, cara mengucapkan, dan cara memproduksi suara dengan intonasi yang baik yang disebut teknik vokal. Peningkatan teknik vokal, pada dasarnya sulit dilakukan, apabila tidak dilatih, diasah dan dicoba secara teratur Pramayudha,(2010: 65). Namun, hal itu bisa dilakukan jika menggunakan beberapa teknik dalam bernyanyi yang disebut teknik vokal.

Sejalan dengan konsep di atas bahwasanya teknik vokal mempunyai Unsur-unsur yang terdiri dari sikap tubuh yang baik, cara bernafas, cara mengucapkan, dan cara memproduksi suara dengan intonasi yang baik di dalam bernyanyi. Adapun teknik vokal di dalam pemandu nyanyian jemaat (PNJ) yang mempunyai teknik sebagai berikut Berdasarkan hasil penelitian yang dilakukan pada tanggal 17 Desember 2017 diketahui bahwa di dalam PNJ GKJ Ngesrep terdiri dari tiga petugas PNJ yang memiliki teknik vokal yang berbeda-beda dalam 
satu ibadah. Adapun Pemandu Nyanyian Jemaat yang pertama yaitu Ibu Maria Denok yang memiliki sikap tubuh yang baik pada saat bernyanyi dan suaranya lantang dengan artikulasi yang jelas, akan tetapi pada teknik pernafasannya kurang begitu baik karena masih menggunakan pernafasan dada, contohnya dalam Materi lagu yang dinyanyikan yaitu KJ 84 : 1, 3 yang berjudul "Ya Yesus, Dikau Kurindukan"

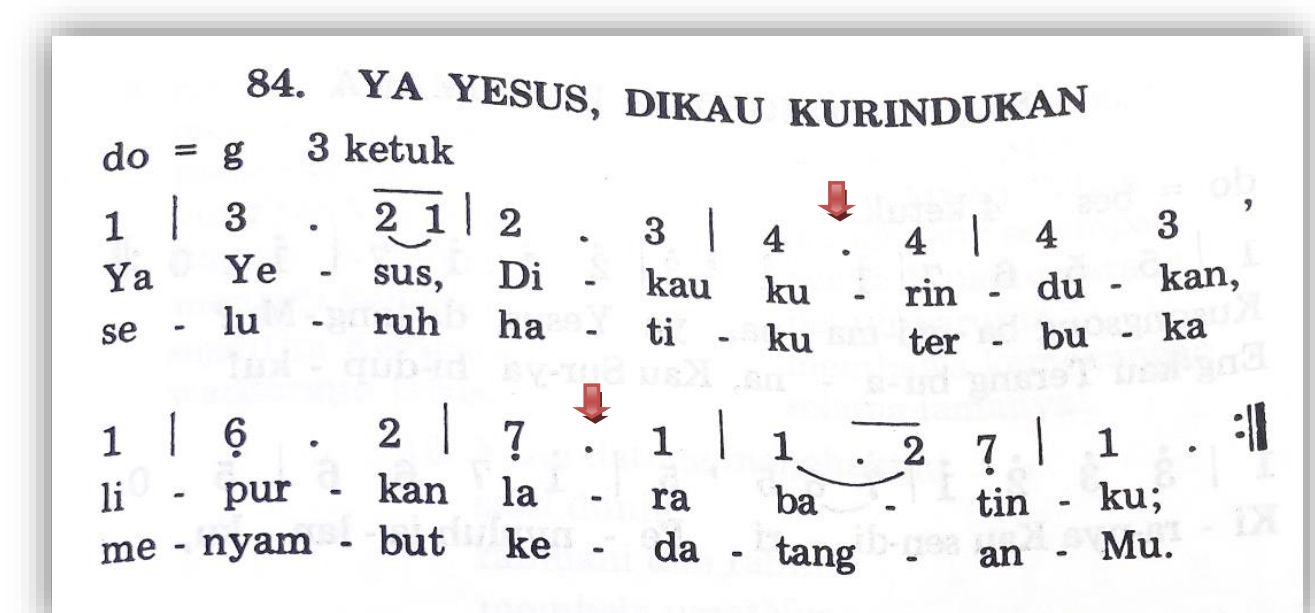

Gambar 12. Kidung Jemaat Nomor 84

(Sumber : Buku Kidung Jemaat, 2005:84)

Pada baris pertama lagu ini phrase pernafasan yang seharusnya nafas diambil pada saat bar terakhir yang memiliki tanda petik atas, namun pergantian nafas diambil pada bar ke empat ketukan ke dua antara "fa". Begitupula pada baris kedua, Pemandu Nyanyian Jemaat yang pertama juga mengambil nafas yang salah, pergantian pernafasan seharusnya diambil pada bar terakhir, namun Pemandu Nyanyian Jemaat mengambil nafas pada bar ke tiga ketukan ke dua diantara "si" dan "do". Kemudian pada teknik Pemandu Nyanyian Jemaat yang kedua dan ketiga yaitu ibu Tri Iswanto dan Ibu Lina Bagus yang memiliki teknik vokal degan sikap tubuh yang baik, dan teknik pernafasan yang cukup baik 
dengan artikulasi yang jelas, akan tetapi kurang begitu lantang dalam benyanyi yang mengakibatkan terjadinya harmonisasi dalam Pemandu Nyanyian Jemaat juga kurang baik, karna Pemandu Nyanyian Jemaat yang pertama memiliki suara yang lantang, ketika Pemandu Nyanyian Jemaat yang pertama menurunkan suaranya yang lantang menjadi agak lembut hasilnya suara Pemandu Nyanyian Jemaat tidak terdengar oleh jemaat dan pendeta yang mengakibatkan tempo yang terjadi dalam pujian tersebut menjadi berubah, adapun untuk mempertegas hal tersebut disertakan contoh lagu KJ 362 : 1, 2 yang berjudul'” Aku Milikmu, Yesus, Tuhanku Sebagai Berikut:

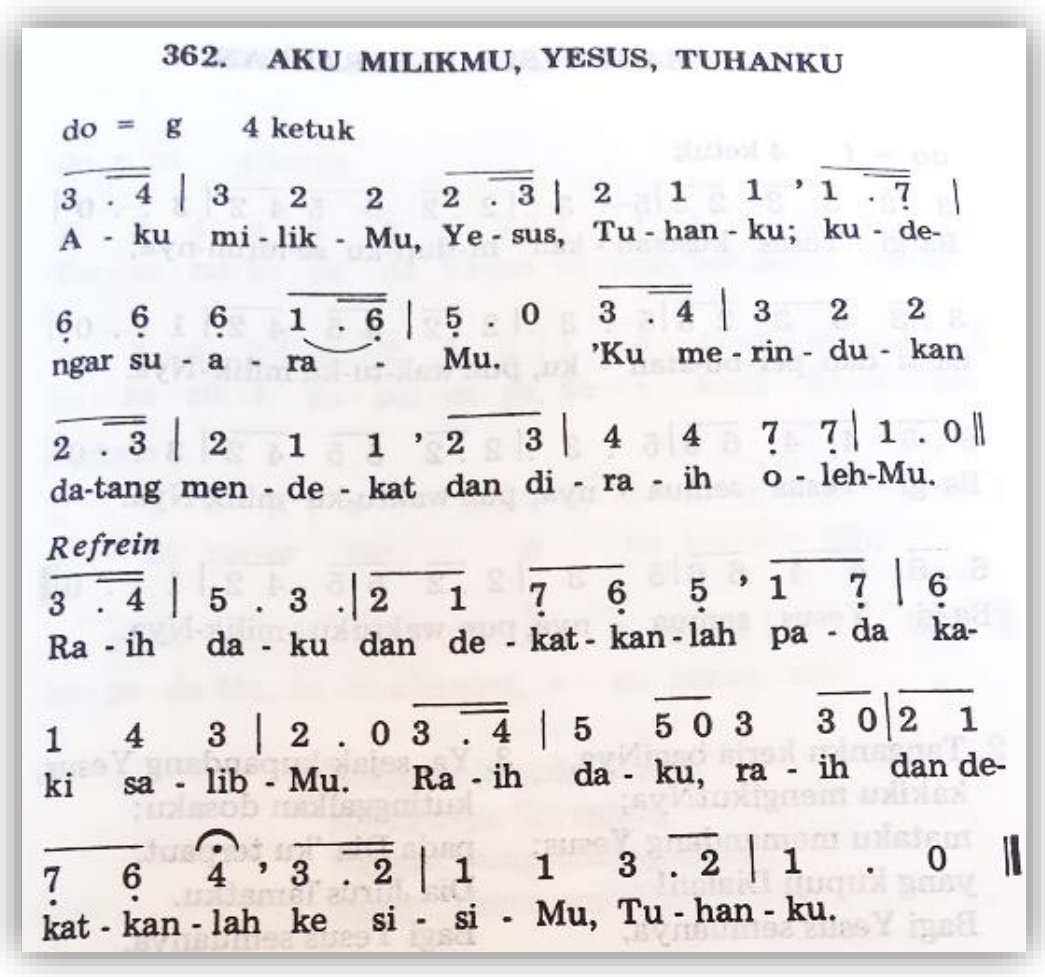

Gambar 13. Kidung Jemaat Nomor 362

(Sumber : Buku Kidung Jemaat, 2005:362)

Pada lagu ini menceritakan tentang diri kita yang rindu dekat dengan

Tuhan Yesus dan menyerahkan hidup kita sepenuhnya hanya kepadaNya, kita 
menyatakan bahwa hidup kita adalah milikNya, dalam lagu ini seharusnya dinyanyikan dengan tempo yang cepat dan riang dengan birama 4/4, namun ketika pemusiknya/organisnya sudah berada pada tempo yang tepat pada pertengahan lagu Pemandu Nyanyian Jemaat jadi melambat dan jatuhnya lagu menjadi tidak riang.

Berdasarkan konsep dan pemaparan di atas dapat ditarik kesimpulan bahwa teknik vokal dalam bernyanyi mempunyai unsur-unsur yang terdiri dari sikap tubuh yang baik, cara bernafas, cara mengucapkan atau intonasi adapun di dalam teknik vokal dalam Pemandu Nyanyian Jemaat (PNJ) yang terdiri dari 3 orang penyanyi dengan teknik vokal yang berbeda-beda yang memiliki kelebihan dan kelemahan masing-masing antara lain pada penyanyi yang pertama memiliki teknik pernafasan yang kurang baik akan tetapi suara pada saat bernyanyi lantang dan artikulasiya jelas, kemudian pada penyanyi yang ke 2 dan tiga memiliki kelemahan yang sama yaitu pada teknik suaranya yang kurang lantang, hal tersebut yang mengakibatkan terjadinya harmonisasi yang kurang baik pada saat bernyanyi dalam peribadatan di GKJ Ngesrep. Untuk mempertegas dari konsep dan pendeskripsian di atas peneliti menambahkan hasil dari penelitian yaitu hasil wawancara kepada PNJ yaitu kepada Ibu Denok berikut hasil petikan wawancaranya:

'......Dalam bernyanyi menjadi petugas Pemandu Nyanyian Jemaat di GKJ Ngesrep kami berangotakan 3 orang dengan karakter suara yang berbeda-beda, teknik bernyanyi yang kami lakukan kami menyadari bahwa masih banyak kekurangan dalam bernyanyi yang baik dan benar hal tersebut dikarnakan jadwal latihan yang kurang dan pemahaman lagu yang kurang, dan tenaga pengajar atau pelatih tidak ada....." 
Berdasarkan dari hasil wawancara di atas dapat ditarik kesimpulan bahwa petugas yang menjadi PNJ di GKJ Ngesrep berangotakan 3 orang yang mempunyai karakter suara yang berbeda dan mempunyai kelamahan dan kelebihan masing-masing dalam teknik bernyanyi khusunya pada saat menjadi petugas PNJ di GKJ Ngesrep. Adapun kekurangan yang ada pada anggota PNJ dikarenakan beberapa faktor yaitu kurangnya pemahan lagu dan jadwal latihan, dan tidak adanya tenaga pelatih vokal hal tersebutlah yang menyebabkan harmoniasi yang kurang baik pada saat bernyanyi dalam tugas Ibadah di GKJ Ngesrep.

\subsubsection{Teknik Pernafasan PNJ GKJ Ngesrep}

Bernafas merupakan irama yang sangat alamiah dalam kehidupan. Pernafasan yang teratur akan menciptakan irama yang menentramkan. Pernafasan dalam bernyanyi tentu berbeda dengan pernafasan sehari-hari. Ada tiga macam penafasan yang digunakan dalam setiap aktifitasnya. Menurut Tim Pusat Musik Liturgi (2009: 9) yaitu pernafasan pernapasan dada, pernapasan perut, dan pernapasan diafragma

Berdasarkan konsep di atas adapun teknik pernafasan yang dipakai oleh anggota PNJ yaitu memakai teknik pernafasan diafragma. Teknik ini dilakukan dengan cara menekankan diafragma yang melintang antara rongga dada dan perut membesar dan hal ini menyebabkan udara dengan leluasa akan mengisi paru-paru. Teknik ini baik digunakan pada saat menyanyi karena volume udara yang disimpan lebih banyak. Teknik pernafasan yang dilakukan oleh anggota PNJ dengan mengambil posisi berdiri tegap sebelum memulai bernyanyi. Para anggota 
PNJ melakukan latihan pernafasan diafragma dengan cara sbagai berikut : kedua tangan di pinggang, kemudian menghirup udara lewat hidung, dan dimasukkan ke perut sehingga perut membuncit, baru dihembuskan perlahan melewati mulut dengan melafalkan bunyi "eshh..." sehingga berdesis. Latihan teknik ini dilakukan berulang dalam jangka waktu sekitar 3-5 menit, setelah latihan teknik pernafasan di anggap selesai para anggota PNJ pun mempersiapkan diri pada posisi untuk bernyanyi, akan tetapi pada saat penampilannya masih kerap terjadi kesalahan dalam teknik pernafasannya dikarenakan minimnya latihan dan pemanasan untuk beryanyi dalam kegiatan peribadatan. Faktor lain juga yaitu teknik pernafasan yang dipakai pada saat latihan masih banyak yang belum sama dan cara pengolahan tekniknya belum stabil dan rileks hal ini juga dipertegas dari hasil wawancara oleh Ibu Lina Hadi yang mengatakan bahwa

"......Anggota petugas Pemandu Nyanyian Jemaat
masih sangat kurang dalam proses latihannya apalagi
untuk berlatih teknik pernafasan saya melihat proses
latihan mereka hanya dilakukan pada saat sebelum
tampil dengan berlatih secara sederhana baik berlatih
vokal maupun teknik pernafasan untuk
bernyanyinya....,

Berdasarkan konsep dan hasil pemaparan di atas dan dipertegas oleh hasil wawancara dapat ditarik kesimpulan bahwa di dalam teknik pernafasan mempunyai beberapa teknik yaitu dada, pernapasan perut, dan pernapasan diafragma, adapun teknik pernafasan anggota PNJ pakai adalah dengan mengunakan teknik pernafasan diafragma. Teknik tersebut mereka latih pada waktu sebelum tampil dalam kegiatan peribadatan di GKJ Ngesrep. Kurangnya latihan dan pemahaman pada teknik pernafasan bagi para anggota PNJ yang 
sering kali membuat angota PNJ melakuan kesalahan dalam proses teknik bernyanyi. Hal itu juga dipertegas oleh Ibu Lina yan g mengatakan untuk saat ini proses latihan anggota PNJ masih sangat kurang yang membuat mereka terkadang melakukan kesalahan dalam teknik bernyanyinya. Adapun untuk mempertegas peneliti menambahkan gambar proses latihan PNJ GKJ Ngesrep.

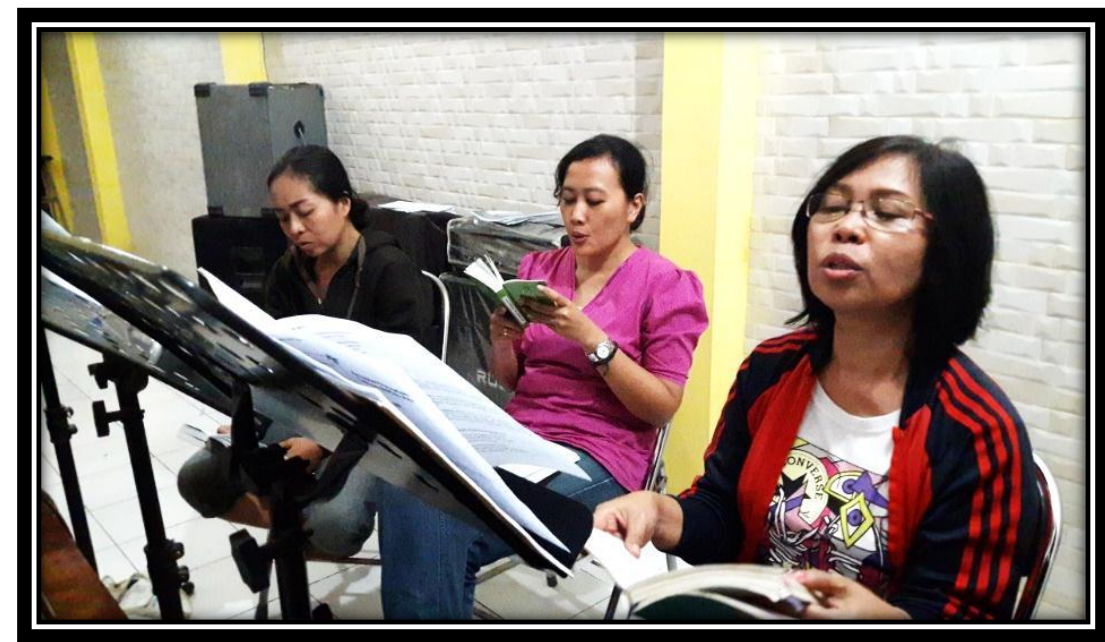

Gambar 14. Pemandu Nyanyian Jemaat Sedang Berlatih untuk Tugas Ibadah (Sumber : Bella Monica Paula, 16 Desember 2017)

\subsubsection{Pengucapan/Artikulasi di dalam Pemandu Nyanyian Jemaat GKJ}

\section{Ngesrep}

Menurut Soewito (1996: 15) pengucapan atau artikulasi sangat penting dalam bernyanyi. Kata-kata harus diucapkan dengan baik dan jelas. Berkaitan dengan artikulasi, Tim Pusat Musik Liturgi (1992: 56), menyatakan bahwa: "Bernyanyi dengan kata-kata, dimaksudkan agar pesan dari kata-kata itu dapat dimengerti, oleh karena itu sebagai penyanyi kita harus meningkatkan ucapan kata, karena kata-kata yang dinyanyikan, mudah menjadi kabur. Apalagi dalam bernyanyi bersama, cara membentuk huruf hidup dan mati harus sama, dan seragam hingga nampak kesatuan dari paduan suara." 
Teknik pembentukan suara merupakan hal yang penting dalam teknik vokal, terutama pengucapan huruf vokal dan konsonan, diftong dan huruf mati bentuk mulut yang benar. Dalam pengucapan huruf hidup sebagai berikut : (1) Huruf (a) diucapkan dengan cara membuka mulut yang tidak terlalu lebar, tidak terlalu ditekan, tidak terlalu dilepas, agar suara yang terbentuk tidak terlalu tajam dan pecah. Suara harus didukung dengan adanya getaran dalam rongga mulut sehingga terdengar utuh (2) Huruf (i) diucapkan dengan cara membuka mulut agak sempit . Udara yang keluar dari mulut diusahakan dapat mengetarkan rongga hidung (3) Huruf (u) diucapkan dengan cara mulut seperti melafalkan huruf 'O' tetapi agak disempitkan sedikit, serta kedua bibir agak di tonjolkan ke depan sedikit (4) Huruf (e) diucapkan dengan cara membuka mulut agak lebih lebar dari huruf "i”, dan sudut bibir agak kesamping serta rongga mulut dibuka cekung kebelakang, sehingga pengucapan huruf '"ee' terdengar indah dan tidak pecah. (5) Huruf (o) diucapkan caea membuka mulut agak lebar bibir di bentuk bulat dan rongga mulut ckung besar.

Pengucapan diftong ai, ue, eo memakai dasar pengabungan huruf (i), (e), dan (o) secara benar, yaitu dengan mengucapkan secara jelas sesuai dengan bentuk mulut seperti pengucapan huruf hidup. Adapun di dalam Pembentukan huruf konsonan adalah sebagai berikut : (1) Konsonan p, b, m, dibentuk dengan mempertemukan dua bibir yaitu bibir atas dan bibir bawah. (2) Konsonan f, v, w, dibentuk dengan mempertmukan antara bibir dan gigi atas. (3) Konsonan d, 1, r, n, $\mathrm{s}, \mathrm{t}, \mathrm{z}$, dibentuk dengan mempertemukan antara ujung lidah dengan langt-langit keras (4) Konsonan c dan j, serta huruf sengau ( sy dan ny) dibentuk dengan 
mempertmukan antara lidah bagian tengah dengan langit-langit bagian tengah (5) Konsonan g, k, q, dan $\mathrm{x}$, serta huruf sengau (ng dan kh) dibentuk dengan mempertemukan antara lidah bagian pangkal dengan langit -langit lunak serta diikuti dengan suara berdesis. (6) Konsonan h, dibentuk dengan cara tanpa melibatkan salah satu artikulasi.

Berdasarkan konsep dan pendeskripsian di atas dapat ditarik kesimpulan bahwa teknik artikulasi di dalam bernyanyi mempunyai teknik di dalamnya dengan Artikulasi adalah cara mengucapkan kata-kata dalam menyanyi agar pesan lagu dapat dimengerti dan dipahami pendengar. Adapun Faktor-faktor yang perlu diperhatikan untuk mendapatkan artikulasi yang baik, antara lain sikap badan yang tegap, posisi mulut yang benar, latihan vokalisis, pembentukan bunyi vokal, dan pembentukan bunyi konsonan.

Sejalan dengan konsep di atas, adapun teknik artikulasi yang diapakai Pemandu Nyanyian Jemaat dalam bernyanyi di GKJ Ngesrep juga memakai teknik artikulasi yang baik seperti penguacapan huruf vokal konsonan, diftong, dan huruf mati dengan jelas. Hal tersebut dapat dilihat dari teknik mereka saat bertugas menjadi Pemandu Nyanyian Jemaat dalam ibadah yang membawakan lagu-lagu pujian dengan salah satu contoh lagu yang berjudul "Hujan Berkat Kan Tercurah" diambil dari KJ $403: 1,2$ berikut petikan lirik lagunya:

1. Hujan berkat 'kan tercurah, itulah janji kudus:

hidup segar dari sorga 'kan diberi Penebus.

Reff:

Hujan berkatMu itu yang kami perlu: 
Sudah menetes berkatMu, biar tercurah penuh!

2. Hujan berkat 'kan tercurah, hidup kembali segar.

Di atas bukit dan lurah bunyi derai terdengar.

Reff:

Di dalam pengalan lirik lagu di atas bannyak mengunakan akhiran huruf konsonan seperti lirik di atas yaitu hujan berkat kan tercurah, itulah janji kudus karena terdapat 6 huruf konsonan pada akhir kata hal tersebut yang mengaharuskan penyanyi khususnya PNJ harus dengan benar di dalam pengucapan artikulasinya, supaya makna yang terdapat di dalam lagu tersebut bisa tersampaikan dengan baik dan benar kepada seluruh jemaat yang ikut serta di dalam peribadatan. Untuk mempertegas hal tersebut peneliti menambahkan deskripsi hasil wawancara dengan jemaat GKJ Ngesrep yaitu dengan bapak Agus Nugroho berikut petikan wawancaranya:

“... ya bisa dibilang saat PNJ menyanyikan pujipujian sangat bagus pengucapan katanya, karena setiap saya beribadah saya bisa mendengarkan dengan khikmat ketika Pemandu Nyanyian Jemaat bernyanyi, dan sayapun bisa mengambil makna dari lagu yang dinyanyikan oleh PNJ...."

Berdasarkan kutipan hasil wawancara, bahwa teknik artikulasi PNJ dalam bernyanyi sudah baik, hal tersebut dapat dilihat dari pendeskripsian di atas dimana jemaat bisa mendengarkan dengan baik dan jemaat bisa memahami makna yang terkandung dalam lirik lagu pujian yang dinyanyikan oleh PNJdi GKJ Ngesrep. Berikut peneliti menambahkan foto pada saat PNJbertugas dalam ibadah di GKJ Ngesrep : 


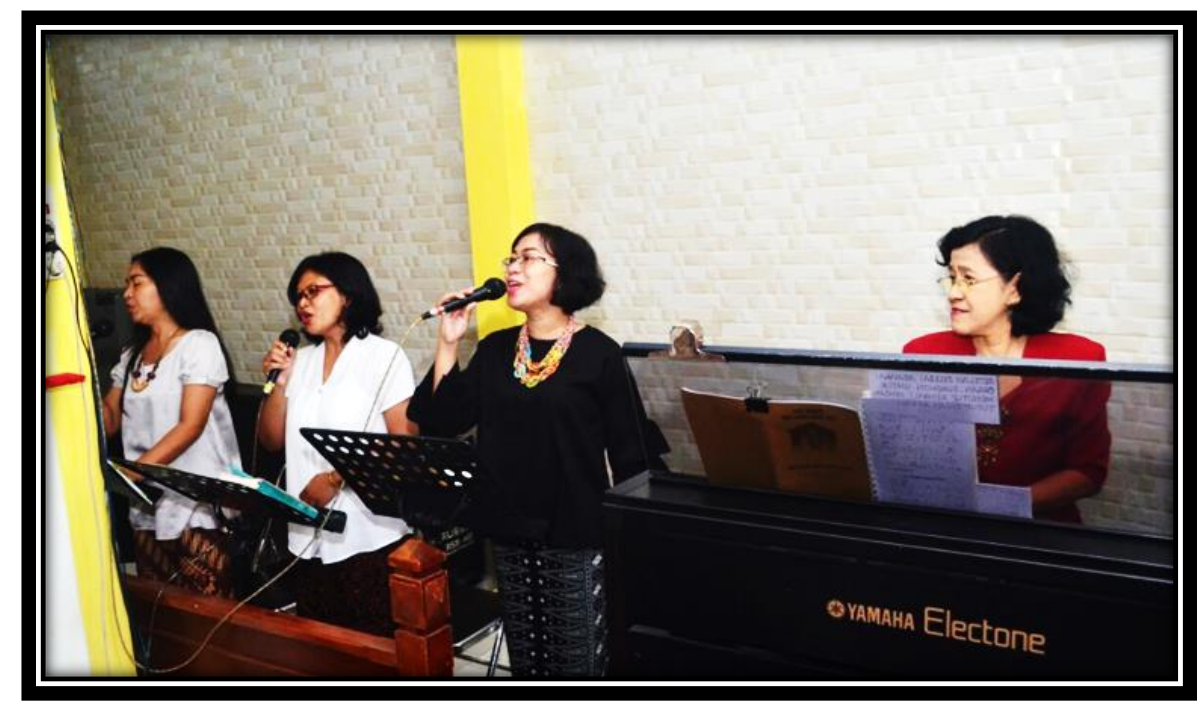

Gambar 15. Pemandu Nyanyian Jemaat Sedang Bertugas Dalam Ibadah (Sumber : Bella Monica Paula, 24 Desember 2017)

\subsubsection{Teknik Resonansi Pemandu Nyanyian Jemaat di GKJ Nesrep}

Menurut Rahardjo (1990: 13). Organ tubuh manusia yang berfungsi memantulkan getaran suara yang ditimbulkan oleh pita suara disebut resonator, sedangkan fungsi resonator adalah membantu menguatkan getaran suara sehingga menjadi suara yang kuat. Organ-organ tubuh yang berfungsi sebagai resonator adalah rongga dada, rongga mulut, rongga hidung, rongga nasopharynxe, dan kepala. Fungsi dari semua rongga, terutama rongga yang dapat berubah ialah menimbulkan perbedaan warna suara. Semakin banyak udara yang termuat dalam rongga-rongga resonansi tersebut, maka semakin bulat suara yang ditimbulkan. Tim Pusat Musik Liturgi, (1992: 37). Resonansi juga dapat dikatakan suatu gejala bunyi yang dikembalikan dari suatu ruangan, semacam gema yang timbul karena adanya ruangan berdinding keras sehingga sanggup memantulkan suara. Tanpa ruangan resonansi, pita suara hanya menimbulkan bunyi yang lemah karena panjangnya hanya $1,5-2 \mathrm{~cm}$. Dengan adanya resonansi, suara manusia menjadi 
keras, indah, dan gemilang. Dari pendapat di atas, dapat disimpulkan bahwa resonansi adalah suatu bunyi yang timbul dari suatu sumber getaran yang berongga, yang berfungsi untuk memperluas dan memperindah suara.

Sejalan dengan konsep tersebut di dalam teknik resonasi PNJ masih banyak yang belum mampu mencapai resonansi yang sesuai dengan nada dasar lagu yang dinyanyikan, hal itu dikarenakan jenis suara yang berbeda-beda, untuk jenis suara yang tinggi/sopran/tenor apabila dihadapkan dengan materi lagu yang nada dasarnya tinggi pasti bisa mencapai nada tersebut, namun untuk jenis suara yang rendah/alto/bass akan sulit mencapai nada tinggi, hal itu yang mengakibatkan pada saat bernyanyi masih banyak beberapa lagu yang nada dasarnya tidak sesuai dengan nada dasar asli. Hal tersebut juga dikarnakan yang menjadi petugas PNJ dalam ibadah juga berbeda-beda orangnya sesuai jadwal yang sudah ditetapkan oleh Tim Komisi Seni Budaya (KSB). Untuk mempertegas pendeskripsian di atas peneliti menambahkkan hasil petikan wawancara kepada ibu Nina Woelan :

“.... kami kalo bertugas itu bertiga, tapi karna orangnya yang berbeda-beda setiap minggunya jadi kadang kami kesusahan buat menyamakan suaranya, karena suaranya berbeda-beda, biasanya yang bertugas bisa suaranya yang tinggi-tinggi semua, ada juga yang bertugas suaranya rendah semua, atau ada juga yang campur ada yang tinggi, ada rendah, jadi kadang kami kesusahan menentukan nada dasar...."

Berdasarkan dari konsep dan petikan wawancara di atas dapat disimpulkan bahwasannya teknik resonansi yang dipakai oleh PNJ saat bertugas dengan bernyanyi unison masih belum baik dan benar dikarenakan untuk jenis suara yang tinggi/sopran/tenor apabila dihadapkan dengan materi lagu yang nada dasarnya 
tinggi pasti bisa mencapai nada tersebut, namun untuk jenis suara yang rendah/alto/bass akan sulit mencapai nada tinggi, hal itu yang mengakibatkan pada saat bernyanyi masih banyak beberapa lagu yang nada dasarnya tidak sesuai dengan nada dasar asli jenis suara dan juga yang menjadi PNJ yang bertugas berbeda-beda setiap minggunya.

\subsubsection{Teknik Phrasering pada Pemandu Nyanyian Jemaat di GKJ Ngesrep}

Menurut Soewito (1996: 22), phrasering ialah aturan pemenggalan kalimat bahasa atau kalimat musik menjadi bagian yang lebih pendek, tetapi tetap mempunyai kesatuan arti. Sedangkan menurut Pradoko, phrasering adalah mengelompokkan bagian-bagian kalimat, baik untuk jenis potongan kalimat pertanyaan maupun kalimat jawaban (1997: 40). Menurut Pramayudha (2010: 12) Tekni Phrasering adalah teknik pemenggalan kalimat secara tepat dalam bernyanyi. Phrasering ini penting bagi konsep keseluruhan musikal. Penyanyi diharapkan tidak mengambil napas disembarang tempat namun mengikuti potongan kalimat pada tanda dalam partitur seperti koma, istirahat, titik.

Sejalan dengan konsep yang telah dipaparkan di atas adapun teknik prhasering di dalam PNJ Ngesrep yang masih sering mengunakan teknik yang salah atau tidak tepat dikarenakan pernafasan yang juga kurang baik, berikut disertakan contohnya dalam lagu KJ 84: 1 yang berjudul "Ya Yesus Dikau Kurindukan". 
84. YA YESUS, DIKAU KURINDUKAN

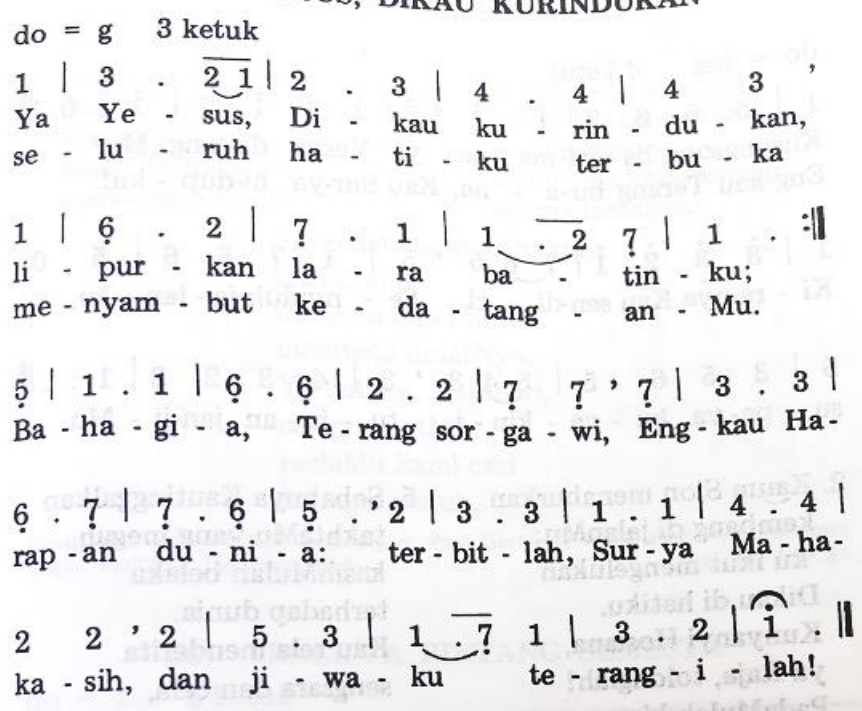

Gambar 16. Kidung Jemaat Nomor 84

(Sumber : Buku Kidung Jemaat)

Pada lagu di atas dapat dilihat terdapat tanda petik di atas yang menunjukkan pemenggalan kalimat yang menandakan bahwa potongan kalimat berada di tanda petik atas, namun PNJ terkadang masih belum mampu memenggal kalimat dengan baik dikarenakan pernafasan PNJ yang juga belum sempurna, sehingga mengakibatkan frasering/pemenggalan kalimat yang kurang tepat. Pada lagu di atas pada baris pertama tanda petik atas berada di bar terakhir jadi nafas dan pemenggalannya harus berhenti di bar terakhir, namun masih ada PNJ yang memenggal di bagian bar ketiga ketukan pertama pada kata "di" kemudian PNJ nafas lalu dilanjut bernyanyi "Kau Kurindukan" seharusnya dari bar pertama sampai tanda petik satu nafas supaya pemenggalannya bagus dan tepat.

\subsubsection{Ekspresi Pemandu Nyanyian Jemaat GKJ Ngesrep}

Menurut Soewito (1996: 23), ekspresi adalah cara yang dilakukan penyanyi untuk membawakan lagu dengan baik dari suatu ciptaan sesuai dengan 
jiwa lagu tersebut. Misalnya sedih, gembira, semangat dan lain-lain. Sedangkan menurut Jamalus (1988: 38), ekspresi dalam musik ialah ungkapan pikiran dan perasaan yang mencakup semua nuansa dari tempo, dinamik, dan warna suara dari unsur-unsur pokok musik, dalam pengelompokan frase yang diwujudkan oleh seniman musik/penyanyi, dan disampaikan pada pendengarnya.adapun Ekspresi wajah terutama untuk memberikan informasi tentang suasana emosi individu. Hanya saja menurut Wierzbicka (1995: 45) ekspresi marah, takut, jijik, sedih, ataupun gembira adalah khusus bahasa dan khusus budaya, dan tidak dapat menunjukkan kesamaan mendunia dalam area emosi.

Di dalam bernyanyi sebuah ekspresi sangat penting karena hal tersebut merupakan bagian yang tidak bisa terlepaskan pada saat bernyanyi karena ekspresi sangat penting di dalam menyampaikan pesan atau makna dalam membwakan sebuah lagu. Jamalus (1999 : 11), dalam bukunya mengatakan Untuk mengungkapkan pikiran dan perasaan dengan bernyanyi diperlukan teknik bernyanyi yang melibatkan peranan bagian-bagian dalam dari badan, pusat, saraf, jaringan otot, paru-paru, selaput suara, ekspresi, wajah, sinar mata, semuanya bekerja dengan refleks.

Berdasarkan uraian tersebut ekspresi bernyanyi PNJ pada saat bertugas sudah baik, hal ini dapat dilihat pada saat mereka bernyanyi penghayatan mereka tersampaikan melalui ekspresi yang dikeluarkan oleh PNJ ketika bernyanyi. Setiap pujian memiliki tema masing-masing, yang pertama pada nyanyian penyesalan, PNJ bernyanyi sangat menghayati bahwa benar-benar menyesali dosa 
dan perbuatannya. Hal ini dapat dilihat dari nyanyian penyesalan yang diambil dari KJ 462: 1 :

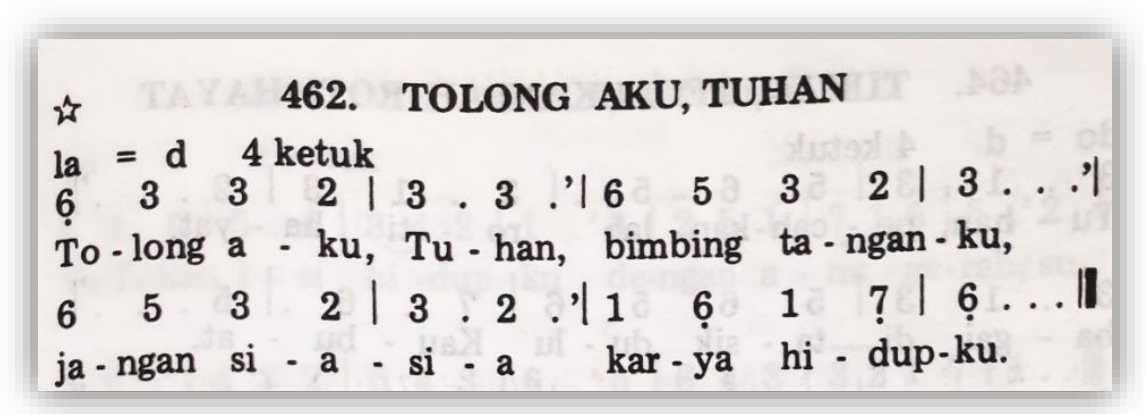

Gambar 17. Kidung Jemaat Nomor 462

(Sumber : Buku Kidung Jemaat)

Pada lagu di atas menceritakan bahwa kita meminta tolong pada Tuhan untuk membimbing hidupnya, dan pada lagu ini ekspresi para PNJ sedih, dengan dagu berkerut, dan dengan kerendahan hati memohon pada Tuhan seakan masuk dalam cerita dari lirik lagu yag dinyanyikan. Berikut foto ekspresi PNJ ketika menyanyinyan nyanyian penyesalan dari KJ $462: 1$

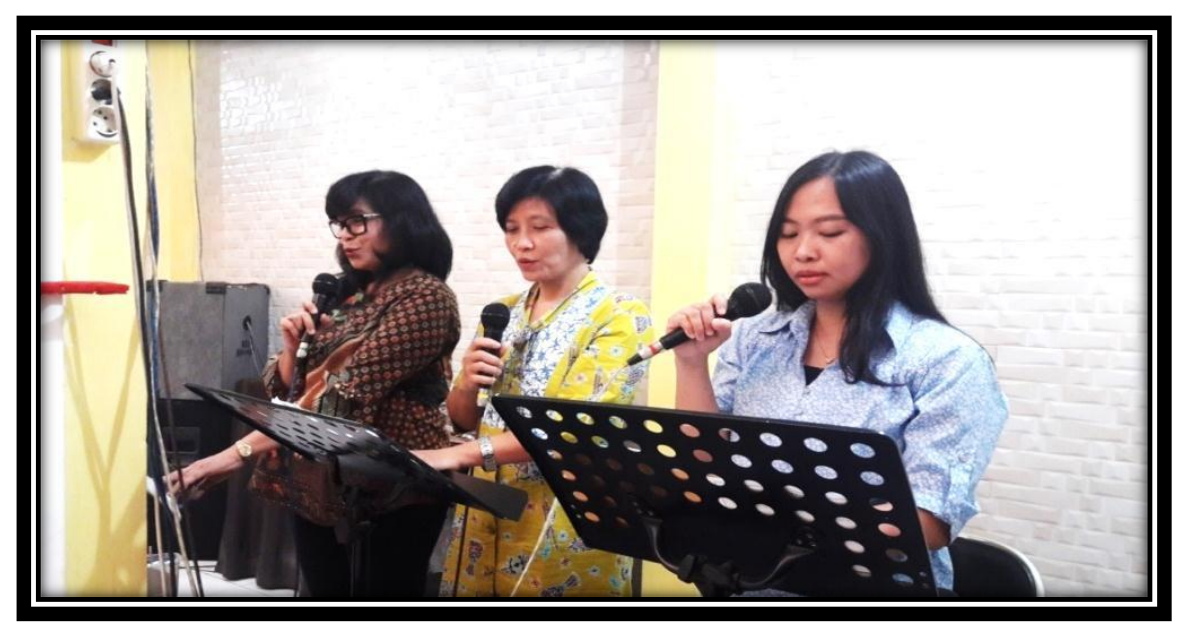

Gambar 18. PNJ Berekspresi sedih Saat Bertugas Menyanyikan Lagu Penyesalan

(Sumber: Bella Monica Paula, 24 Desember 2017) 
Kemudian dilanjutkan pada lagu yang kedua yaitu yang mempunyai ekspresi gembira pada nyanyian penutup yang diambil dari KJ $426: 1$ : berikut disertakan gambar lagu yang berjudul "Kita Harus Membawa Berita"

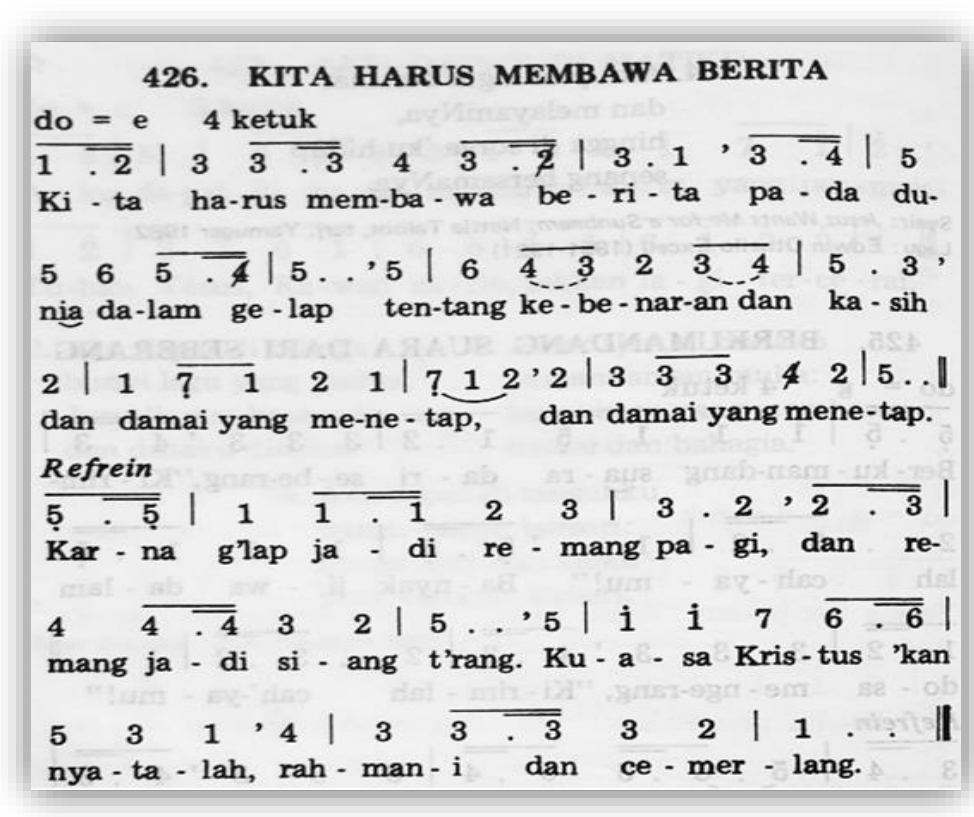

Gambar 19. Kidung Jemaat Nomor 426

(Sumber : Buku Kidung Jemaat)

Berdasarkan petikan lagu di atas yang menceritakan bahwa dalam dunia ini yang penuh dengan kegelapan kita harus keluar membawa kabar pada dunia tentang kebenaran, kasih, dan damai yang datang dari Kristus. Ekspresi pada lagu ini yaitu ekspresi riang hal tersebut dapat diekspresikan oleh PNJ ketika menyanyikan lagu dengan ekspresi riang, senang, penuh sukacita sehingga pesan atau makna yang terkandung dalam nyanyian penutup tersebut tersampaikan kepada jemaat yang mengikuti ibadah di GKJ Ngesrep. Untuk mempertegas hal tersebut peneliti menambahkan gambar PNJ Pada saat mebawakan lagu yang berjudul Kita Harus Membawa Berita. 


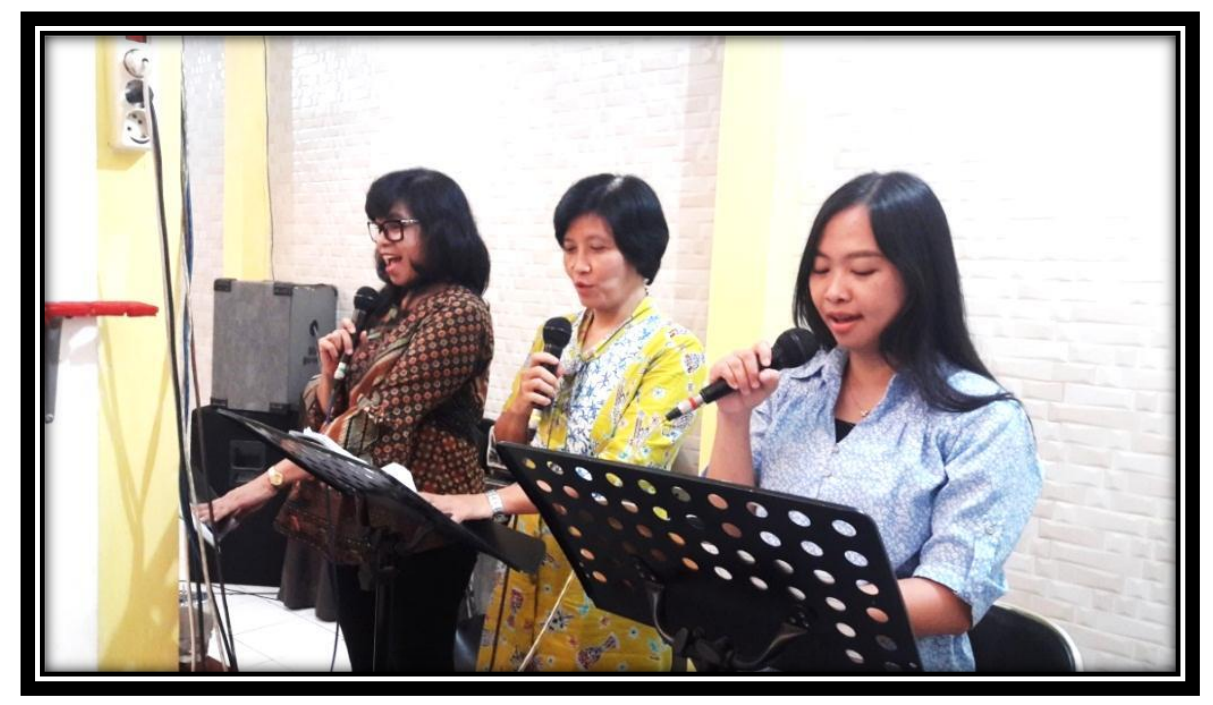

Gambar 20. PNJ Ekspresi Gembira dengan Tema Lagu Riang Menyambut Tuhan (Sumber : Bella Monica Paula, 24 Desember 2017)

\subsection{Peran Pemandu Nyanyian Jemaat GKJ Ngesrep}

\subsubsection{Procantor}

Gracia Leonora Simanjuntak (2013:13) mengatakan bahwa Perkembangan musik gereja saat ini tidak terlepas dari banyak faktor yang terkait di dalamnya. Salah satunya adalah keberadaan kelompok penyanyi yang berfungsi memimpin nyanyian jemaat. Kelompok tersebut sering disebut dengan berbagai macam istilah seperti procantor atau cantoria. Penggunaan istilah ini sering kali membingungkan jemaat dalam memahami arti dan fungsi dari istilah tersebut. Untuk itu, perlu ada sebuah penjelasan tentang istilah procantor, cantoria. Gracia Leonora Simanjuntak

Menurut Tim Badan Pekerja Majelis Sinode Gereja Kristen Indonesia BPMS GKI (2012: 101) procantor harus mampu bekerja sama dengan Pemandu Nyanyian Jemaat, pendeta, penatua dan umat. Lagu yang dipilih dalam nyanyian jemaat memiliki peran yang sangat penting, yaitu sebagai penuntun untuk 
membantu jemaat melakukan perjumpaan dengan Tuhan dalam peribadahan. Oleh karena itu apabila musik iringan tidak disiapkan dengan baik, maka dapat mengganggu jalannya ibadah. Pemandu Nyanyian Jemaat (PNJ) perlu memiliki kompetensi dan pengetahuan yang memadai mengenai nyanyian jemaat.

Berdasarkan penjelesan dari pendeskripian di atas dapat ditarik kesimpulan bahwasanya procantor atau cantoria, suatu kelompok penyanyi yang berfungsi memimpin nyanyian jemaat. Adapun peran yang sangat penting dalam menjadi procantor yaitu sebagai penuntun untuk membantu jemaat melakukan perjumpaan dengan Tuhan dalam peribadahan.

Sejalan dengan hal tersebut di dalam GKJ Ngesrep istilah procantor atau cantoria lebih sering dikenal dengan sebutan nama Pemandu Nyanyian Jemaat (PNJ) di dalam ibadah di GKJ Ngesrep suatu nyanyian untuk peribadatan yang disiapkan oleh anggota PNJ GKJ Ngesrep yang bertugas pada saat peribadatan berlangsung. Seperti yang diungkapkan oleh Pdt. Iskak Dodie Irawan, S. Si bahwa, Tim PNJ GKJ telah menyusun liturgi atau tata ibadah selama satu tahun yang kemudian dibukukan dan disebut "Kotbah Jangkep". Pada buku tersebut sudah terdapat tema, bacaan alkitab dan nyanyian nyanyian yang semuanya saling mendukung. Pdt. Iskak Dodie Irawan, S. Si menambahkan bahwa, buku "Kotbah Jangkep" ini diberikan kepada pengkotbah dengan materi mingguan bukan tahunan. Tentang pemilihan nyanyian, yang terdapat pada buku kotbah jangkep hanya sebagai acuan bukan menjadi keharusan untuk menggunakan nyanyian nyanyian yang sudah dipilih oleh Tim Sinode PNJ GKJ Ngesrep. Artinya, pengkotbah bisa memilih sendiri nyanyian yang sesuai 
dengan isi kotbah. Nyanyian di dalam liturgi harusnya saling berhubungan dan saling mendukung satu dengan yang lainnya.

Nyanyian merupakan bagian integral dari liturgi. Jadi nyanyian menjadi unsur penting dalam ibadah, karena nyanyian turut membantu tercapainya tujuan liturgi (ibadah) itu sendiri. Nyanyian dalam liturgi disusun bukan tanpa dasar, yang menjadi dasardari liturgi tersebut adalah sejarah perjumpaan manusia dengan Tuhan. Sejarah perjumpaan ini didasarkan pada sejarah karya penyelamatan Tuhan, yang intinya adalah Tuhan memanggil kemudian manusia bertobat;Tuhan menyelamatkan kemudian manusia merespon; Tuhan mengutus dan memberkati. 3 Pemandu Nyanyian Jemaat bertugas menuntun jemaat menyanyi dengan baik dan benar di dalam ibadah. PNJ GKJ Ngesrep berperan membantu jemaat membenarkan nyanyian yang selama ini dinyanyikan dengan salah dan membantu jemaat menyanyikan lagu-lagu baru atau jarang dinyanyikan baik secara langsung maupun tidak. Membaca notasi lagu dengan tepat dan tempo sesuai dengan musik iringan akan membantu jemaat untuk menyanyi dengan baik. Dalam ibadah di GKJ Ngesrep dan peran Pemandu nyanyian jemaat belum tercapai dengan maksimal bila dilihat dari unsur-unsur musik seperti melodi, irama, harmoni dan ekspresi. Berikut ini adalah peran PNJ dalam kelompok nyanyian liturgi mulai dari nyanyian pembukaan, nyanyian pujian, nyanyian penyesalan, nyanyian kesanggupan, nyanyian persembahan dan nyanyian pengutusan: adapun tugas yang pertama bagi PNJ adalah sebagai berikut : 
Pertama Nyanyian Pembukaan Nyanyian ini bertujuan mempersiapkan jemaat untuk beribadah dan merupakan panggilan beribadah secara umum. PNJ GKJ Ngesrep berperan memberi semangat dalam mengungkapkan suatu panggilan melalui ekspresi dalam bernyanyi. Gereja Kristen Jawa Ngesrep menggunakan nyanyian dari buku Kidung Jemaat (KJ) dan menetapkan KJ nomor 15 yang berjudul "Berhimpun Semua" sebagai nyanyian pembukaan. Selama observasi hingga penelitian selesai nyanyian ini dinyanyikan disetiap ibadah hari Minggu pukul 06.00 W kemudian yang kedua nyanyian pujian, yang ketiga nyanyian penyesalan, keempat nyanyian kesanggupan yang kelima nyanyian persembahan, yang keenam nyanyian pengutusan kemudian yang terakihir nyanyian penutup hal tersebut yang harus dibawakan seorang procantor yang bertugas yang mana agar dapat mengajak jemaat yang beribadah dengan khusuk.

Sejalan dengan hal tersebut di dalam makalahnya Gracia Leonora Simanjuntak (2013: 30) mengatakan Seorang procantor harus dapat memberikan teladan ketika ia berada di depan sebagai pelayan yang memimpin pujian dan ketika ia melatih jemaat untuk menyanyikan lagu-lagu jemaat. Kehadirannya dalam ibadah jemaat harus memberikan dorongan supaya jemaat yang tidak bisa atau yang belum dapat menyanyi dengan baik dan benar, dibimbing tanpa merasa tertekan karena dominasi suara prokantor.

Adapun Tugas Seorang Procantor dan Tim-nya (cantoria): Memperkenalkan dan mengajarkan lagu baru kepada jemaat; Menyanyikan lagu bersama jemaat dengan cara yang benar dan tepat; Memperbaiki cara 
menyanyikan lagu yang salah, secara langsung atau tidak langsung (jika ternyata lagu tersebut selama ini sudah salah dinyanyikan oleh jemaat); Secara bergantian dapat menyanyikan satu lagu jemaat yang "utuh" dengan berbagai kemungkinan keterlibatan, antara lain: menyanyi secara alternatim (bergilir-ganti) dengan jemaat dan paduan suara, dan lain-lain;Dapat menolong kelangsungan ibadah yang baik dengan melakukan kreativitas lain, misalnya dengan menambahkan gerakan dan tarian (dance and movement in liturgy). atau menyajikan nyanyian persembahan dengan gerak koreografi yang sesuai. Hal-hal tersebut di atas dapat dilakukan oleh seorang procantor dengan dukungan cantoria, paduan suara dan para pemain musik.

Dari penjelasan dan pendeskripsian di atas dapat ditarik kesimpulan bahwa seorang procantor harus memiiki pengetahuan atau pemahan di dalam lagu-lagu gereja untuk peribadatan hal tersebut dapat memberikan teladan ketika ia berada di depan sebagai pelayan yang memimpin pujian dan ketika ia melatih jemaat untuk menyanyikan lagu-lagu jemaat, karena seorang procantor itu harus bisa mengajak jemaat untuk bernyanyi dalam ibadah yang baik.

\subsubsection{Cantoria}

Cantoria berasal dari bahasa Latin cantare yang artinya menyanyi. Sedangkan orang yang menyanyi, dalam bahasa Latin dikenal dengan istilah cantor. Pada akhir tahun 90-an, istilah ini semakin berkembang dan dibuat terjemahan dalam bahasa Indonesia yaitu kantoria terdiri atas kelompok penyanyi yang dipimpin oleh seorang prokantor. Jumlah ideal Cantoria adalah 10\% dari jumlah jemaat, namun bisa saja paduan suara yang bertugas, berfungsi sebagai 
cantoria. Sejalan dengan hal tersebut Simanjuntak (2013: 25) menyatakan bahwa tugas Procantor dan Cantoria antara lain :1). Menyanyikan lagu bersama jemaat dengan cara yang baik dan benar 2). Memperkenalkan lagu-lagu baru kepada jemaat dengan memberikan contoh 3). Mengajarkan lagu tersebut kepada jemaat 4). Memperbaiki cara menyanyikan lagu yang salah, secara langsung atau tidak (jika ternyata lagu tersebut sudah salah dinyanyikan selama ini) 5). Secara bergantian dapat menyanyikan satu lagu "utuh" dengan jemaat

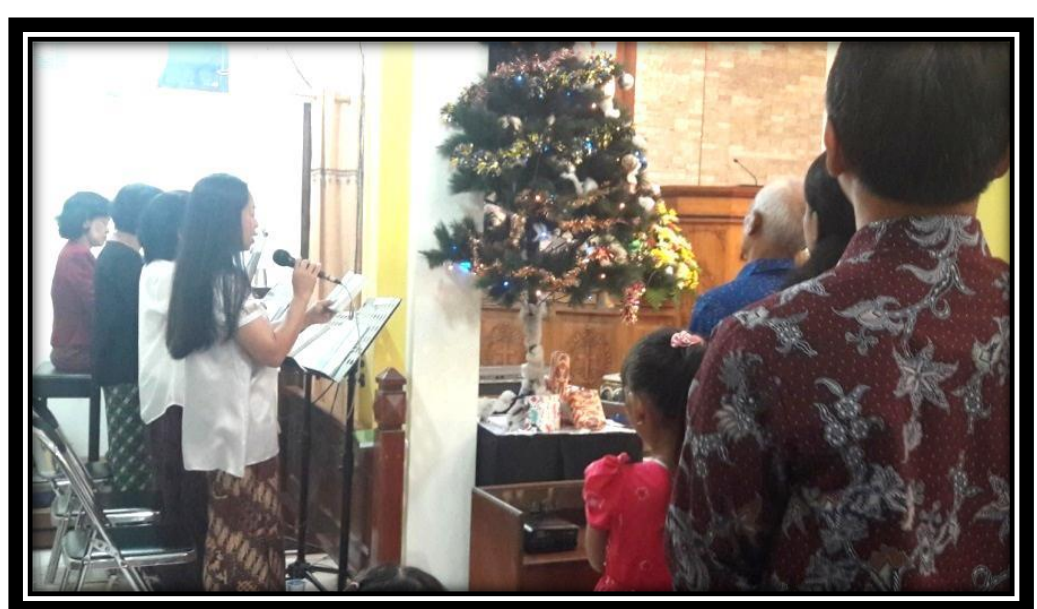

Gambar 21. Pemandu Nyanyian Jemaat yang Bertugas Menjadi Cantoria yang Memakai Baju Warna Putih

(Sumber : Bella Monica Paula, 25 Desember 2017)

Berdasarkan hal tersebut di dalam gereja GKJ Ngesrep tugas cantoria yang lebih dikenal dengan sebutan Pemandu Nyanyian Jemaat (PNJ) mereka sebagai penyanyi di dalam ibadah gereja yang mana tugas cantoria digereja GKJ Ngesrep sebagai pembantu procantor, di GKJ Ngesrep yang bertugas menjadi Cantoria Berjumlah 2 orang yang sudah mempunyai tugasya masing-masing salah satu contohnya ketika sedang bertugas cantoria membantu procantor bernyanyi dengan baik dan benar dalam menyanyikan lagu pujian, sejalan dengan 
hal tersebut dipertegas dengan hasil wawancara kepada salah satu petugas cantoria ibu Lina Hadi berikut petikan wawancaranya:

“......Iya saya sebagai pembantu procantor kadang msih takut salah nada atau lirik jadi kadang kalo susah saya nyanyinya dijauhin miknya dan akhirnya saya gandul sama pemimpinnya procantor itu,,,,,"

Berdasarkan konsep dan pendeskripian di atas dapat ditarik kesimpulan bahwasanya tugas seorang cantoria khusunya di GKJ ngeserep berjumlah 2 orang dimana di dalam bertugas cantoria menjadi pendamping procantor saat bertugas akan tetapi di dalam GKJ Ngesrep cantoria yang bertugas masih belum maksimal dan masih mengandalkan procantor karna yang bertugas menjadi cantoria belum begitu maksimal dalam menjalankan tugasnya dikarnakan hal-hal yang masih banyak belum mereka kusai salah satu contohnya yaitu dari hasil wawancara di atas yang mengatakan ketika mereka bernyanyi terkadang masih takut salah nada atau lirik hal tersebut yang membuat cantoria yang bertugas di GKJ Ngesrep masi belum maksimal. 


\section{BAB V}

\section{SIMPULAN DAN SARAN}

Berpijak dari hasil Penelitian, bab IV Mengenai gambaran umum Penelitian di wilayah Kota Semarang khusunya kecamatan Banyumanik dan Pembahsan permasalahan yaitu: TEKNIK VOKAL DAN PERAN PEMANDU NYANYIAN JEMAAT DI GEREJA KRISTEN JAWA NGESREP KOTA SEMARANG

\subsection{Kesimpulan}

Berdasarkan pembahasan yang pertama yaitu mengenai Teknik vokal Pemandu Nyanyian Jemaat di GKJ Ngesrep. Dapat ditarik kesimpulan bahwa teknik vokal dalam Pemandu Nyanyian Jemaat (PNJ) yang terdiri dari 3 orang penyanyi dengan teknik vokal yang berbeda-beda yang memiliki kelebihan dan kelemahan masing-masing antaralain pada beberapa penyanyi memiliki teknik pernafasan yang kurang baik akan tetapi suara pada saat bernyanyi lantang dan artikulasinya jelas, kemudian pada beberapa penyanyi yang lain memiliki kelemahan yang sama yaitu pada teknik suaranya yang kurang lantang, hal tersebut yang mengakibatkan terjadinya harmonisasi yang kurang baik pada saat bernyanyi dalam peribadatan di GKJ Ngesrep.

Berdasarkan pembahasan yang kedua yaitu mengenai Peran Pemandu Nyanyian Jemaat pada proses peribadatan di GKJ Ngesrep dapat ditarik kesimpulan bahwasanya seorang procantor yang memiliki tugas sebagai ketua pemimpin dalam nyanyian peribadatan khusunya di GKJ Ngesrep yang mana 
harus memiliki pengetahuan atau pemahan di dalam lagu-lagu gereja untuk peribadatan hal tersebut dapat memberikan teladan ketika ia berada di depan sebagai pelayan yang memimpin pujian dan ketika ia melatih jemaat untuk menyanyikan lagu-lagu jemaat, karena seorang procantor itu harus bisa mengajak jemaat untuk bernyanyi dalam ibadah yang baik. Adapaun tugas cantoria khusunya di GKJ Ngeserep berjumlah 2 orang di mana di dalam bertugas cantoria menjadi pendamping procantor saat bertugas akan tetapi di dalam GKJ Ngesrep cantoria yang bertugas masih belum maksimal dan masih mengandalkan procantor dikarenakan yang bertugas menjadi cantoria belum begitu sepenuhnya menguasai Tugas yang harus dilakukan salah satunya meteri musik dalam nyanyian peribadatan hal tersebutlah membuat cantoria masih mengandalkan procantor dan masih saling membutuhkan untuk menutupi kekurangan yang ada.

\subsection{Saran}

Berdasarkan kesimpulan yang telah dikemukakan di atas adapun penulis memberikan saran : (1). Untuk menambah kemampuan di dalam bernyanyi khusunya anggota Pemandu Nyanyian Jemaat yang bertugas di Greja GKJ Ngesrep perlu dilakukan evalusi yaitu jadwal latihan yang harus ditambah dan pemahan-pemahan tentang materi lagu harus diperdalam baik dari teknik vokal yaitu teknik pernafasan diafragma, teknik artikulasi teknik resonansi, teknik phrasering, ekspresi. Agar dalam pelayanan peribadatan bertugas menjadi Pemandu Nyanyian Jemaat bisa dengan maksimal sesuai dengan tugas dan tanggung jawab yang telah di berikan kepada Pemandu Nyanyian Jemaat (2). 
Diperlukan juga pelatih yang berkompeten dibidang musik khusunya musik vokal agar PNJ bisa lebih memahami tentang teknik vokal yang baik dan benar sehingga bisa membawa dampak yang positif baik kepada PNJ Maupun jemaat yang mendengarkan pada saat PNJ bertugas (3). Di dalam pemilihan lagu harus sesuai dengan kemampuan PNJ sehingga ketika mendapatkan materi sudah sesuai dengan kemampuan sehingga bisa menghindari kesalahan (4). Untuk yang bertugas sebagai procantor atau cantoria harus bisa lebih memahami peran dan tugas masing-masing sehingga di dalam tugasnya bisa lebih baik dan tidak terjadi kesalahan (5). Procantor dan cantoria atau lebih dikenal sebagai PNJ harus sering berkomunikasi atau berdiskusi tentang tugas-tugas masing-masing, agar dalam pelaksanaan bisa lebih baik (Suharto and Indriyanto 2018). 


\section{DAFTAR PUSTAKA}

\section{Alkitab}

Alkitab. Terjemahan LAI Jakarta. Lembaga Alkitab Indonesia, 2005.

\section{Kamus}

Kamus Besar Bahasa Indonesia. 2005. Jakarta : Balai Pustaka

Poerwadarminta, W. J. S. 1976. Kamus Umum Bahasa Indonesia. Jakarta: Balai Pustaka.

\section{Buku-Buku}

Creswell, J. W. 2010. Research Design. Yogyakarta: Pustaka Pelajar.

Friedman, John. 1992. Empowerment: The Politics of Alternative Development. Massachusetts : Blackwell Publishers.

Hardjana. 1983. Mari Bermain Drama. Pustaka Dian : Jakarta.

Jamallus, 1988. Musik Untuk SPG. Jakarta: Depdikbud.

Koentjaraningrat. 1992. Beberapa Pokok Antropologi Sosial. Jakarta: Dian Rakyat.

Kurniasih, Imas. 2006. Pendidikan Anak Usia Dini. Jakarta : Edukasia.

Komarudin. 1994. Ensiklopedia Managemen University Michigan. Jakarta: Obor Sarana Utama.

Murgiyanto, Sal. 1983. Koreografi. Jakarta: Proyek Pengadaan Buku Pendidikan Menengah Kejuruan.

Moleong, Lexy j. (2007) Metodologi penelitian kualitatif, Penerbit PT Remaja Rosdakarya Offset, Bandung.

Nawawi, H. Hadari. 1991. Metode Penelitian Bidang Sosial. Yogyakarta: Gajah Mada University Press.

Okatara, Bebbi. 2011. 6 Jam Jago Teknik Vocal. Jakarta : Gudang Ilmu. 
Pradoko, Susilo. 1997. Teori Musik Dasar. Yogyakarta: Universitas Negeri Yogyakarta.

Prier, K. E. \& Widyawan, P. 2011. Roda Musik Liturgi. Yogyakarta: Pusat Musik Liturgi.

Pusat Musik Liturgi. 2002. Menjadi Dirigen II Edisi Revisi Membentuk Suara.

Rahardjo, Slamet. 1990. Teori Seni Vokal untuk SMA, Guru, Umum. Semarang : Media Karya

Rohidi, T.R. 2011. Metodologi penelitian seni. Semarang: Cipta Prima Nusantara Semarang.

Simanjuntak, G. L. 2013. Materi Pelatihan Pemimpin Liturgi. Yogyakarta

Soedarsono. 1998. Seni Pertunjukan Indonesia Di Era Globalisasi. Jakarta : Direktorat Jendral Pendidikan Tinggi Departemen Pendidikan Dan Kebudayaan.

Suharto and Indriyanto. 2018. "Preserving Calung Banyumasan through Vocational Education and Its Community." P. 12120 in IOP Conference Series: Materials Science and Engineering, vol. 306, edited by A. G. Abdullah. Bandung: IOP Publishing. Retrieved April 10, 2018 (http://stacks.iop.org/1757-

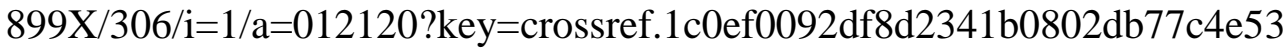
$6)$.

Jazuli, M. (2011). MODEL PEMBELAJARAN TARI PENDIDIKAN PADA SISWA SD/MI SEMARANG. Harmonia: Journal of Arts Research and Education, 10(2). doi:https://doi.org/10.15294/harmonia.v10i2.59

Kusumadewi, L., \& Suharto, S. (2011). PENINGKATAN HASIL BELAJAR SENI MUSIK DENGAN MEDIA AUDIO VISUAL MELALUI METODE BERVARIASI. Harmonia: Journal of Arts Research and Education, 10(2). doi:https://doi.org/10.15294/harmonia.v10i2.63

Adi Sam, T. (2011). PERMAINAN ANAK YANG MENGGUNAKAN NYANYIAN (Kajian Wilayah: Jakarta, Depok, Bogor, Tangerang, dan Bekasi). Harmonia: Journal of Arts Research and Education, 10(2). doi:https://doi.org/10.15294/harmonia.v10i2.57

Suharto, S., Sumaryanto, T., Ganap, V., \& Santosa, S. (2016). Banyumasan Songs As Banyumas People $s$ Character Reflection. Harmonia: Journal of Arts Research and Education, 16(1), 49-56. doi:https://doi.org/10.15294/harmonia.v16i1.6460 
Suharto.(2016). Musikalitas dan Makna Simbolik Pertunjukan Calung Banyumasan di Kabupaten Banyumas. Research Report. Semarang: Lembaga Penelitian Unnes.

Heriwati, S. (2011). METAFORA DALAM CAKEPAN TEMBANG TEMBANG JAWA. Harmonia: Journal of Arts Research and Education, 10(1). doi:https://doi.org/10.15294/harmonia.v10i1.49

PEMANFAATAN DAN PENGEMBANGAN LAGU ANAK-ANAK DALAM PEMBELAJARAN TEMATIK PADA PENDIDIKAN ANAK USIA DINI / TK

Budiarti, M. (2014). KONSEP KEPESINDENAN DAN ELEMEN-ELEMEN DASARNYA. Harmonia: Journal of Arts Research and Education, 13(2). doi:https://doi.org/10.15294/harmonia.v13i2.2781

Hidajat, R. (2014). The Popularity of Waranggana Tayub Malang through Body Exploitation. Harmonia: Journal of Arts Research and Education, 14(2), 72-77. doi:https://doi.org/10.15294/harmonia.v14i2.3288

Widodo, W. (2011). Nuansa Laras Diatonik dalam Macapat Semarangan (Diatonic Scale Atmosphere in Semarang Style Macapat).. Harmonia: Journal of Arts Research and Education, 7(1). doi:https://doi.org/10.15294/harmonia.v7i1.751

Soewito. M. 1996. Teknik Termudah Belajar Vocal. Bandung: Titik Terang.

Sugiman, Stefanus. 2017. Membentuk Karakter Jemaat Yang Melayani Sebagai Perwujudan Kasih Tuhan. Semarang : GKJ Ngesrep.

Sugiyono. 2006. Metode Kuantitatif Kualitatif dan RnD. Bandung: Alfabeta. 2008. Metode Penelitian Pendidikan Kuantitatif Kualitatif dan RnD. Bandung: Alfabeta.

2010. Metode Penelitian Pendidikan Kuantitatif Kualitatif dan RnD. Bandung: Afabeta.

Tim BPMS GKI. 2012. Musik Dalam Ibadah. Jakarta: Grafika KreasIndo.

Tim Liturgi Sinode GKJ. Tanpa tahun. Menuju Pembaharuan Liturgi Gereja Kristen Jawa.

Widyastuti, M.G. 2007. Diktat Perkuliahan Vokal I. Jurusan Pendidikan Seni Musik FBS: UNY 
Wierzbicka, M. Oral Health of Polis Three-year-olds and Mother's Oral HealthRelated Knowledge. Comunity Dental Health [serial online] 2004 [cited 2017 Des 7]. Avaliable from URL:

http://www.ncbi.nlm.nih.gov/pubmed/15228208.

Yayasan Musik Gerejawi. 2005. Kidung Jemaat. Jakarta.

Yudha, Pramayudha. 2010. Buku Pintar Olah Vocal. Yogyakarta: Buku Biru. 


\section{LAMPIRAN}

\section{INSTRUMEN PENELITIAN}

\section{Tujuan}

Observasi pada penelitian ini dimaksudkan untuk mengetahui bentuk penyajian vokal dan peran Pemandu Nyanyian Jemaat di GKJ Ngesrep Kota Semarang. Oleh : Bella Monica Paula

Pedoman Observasi, Wawancara, dan Studi Dokumen

\section{Observasi}

Dalam Penelitian ini hal-hal yang akan diamati langsung mengenai :

A. Jemaat GKJ Ngesrep

a. Kondisi jemaat GKJ Ngesrep

b. Peribadatan jemaat GKJ Ngesrep

c. Persiapan PEMANDU NYANYIAN JEMAAT GKJ Ngesrep Sebelum Melaksanakan Peribadatan

d. Pelaksanaan dan proses peribadatan GKJ Ngesrep

e. Pelayanan PEMANDU NYANYIAN JEMAAT GKJ Ngesrep dalam peribadatan

f. Teknik vokal PEMANDU NYANYIAN JEMAAT

g. Peran PEMANDU NYANYIAN JEMAAT GKJ Ngesrep

h. Materi yang dinyanyikan PEMANDU NYANYIAN JEMAAT dalam peribadatan di Gkj Ngesrep 


\section{STUDI DOKUMENTASI}

\section{Tujuan}

Dokumentasi dimaksudkan untuk menambah kelengkapan data yang berkaitan dengan Bentuk penyajian vokal dan Peran Pemandu Nyanyian Jemaat di GKJ Ngesrep Kota Semarang.

\section{Data Yang Dikumpulkan}

a. Dokumentasi bersumber pada penelitian yang mencakup arsip/dokumen, Buku, foto, vidio rekaman peribadatan, yang dimiliki oleh Gkj Ngesrep

b. Dokumen atau catatan mengenai Profil GKJ Ngersrep, Letak dan sejarah GKJ Ngesrep

c. Data-data Liturgi Kebaktian GKJ Ngesrep

d. Dokumen mengenai peribadatan di GKJ Ngesrep 


\section{WAWANCARA}

Pokok-pokok wawancara ditunjukan kepada ketua Pemandu Nyanyian Jemaat GKJ Ngesrep, Anggota Pemandu Nyanyian Jemaat, Pendeta, Majelis, Jemaat di GKJ Ngesrep Kota Semarang. Data Lengkap informan Yang akan Di wawancarai Sebagai Berikut:

\section{A. Pendeta GKJ Ngesrep}

1. Nama Lengkap :Pdt. Iskak Dodie Irawan, S. Si

2. Jenis Kelamin : laki-laki

3. Usia : 48 th

4. Pendidikan : S.Th

5. Pekerjaan : Pendeta

1. Kapan berdirinya GKJ Ngesrep ?

2. Apa yang melatarbelakangi berdirinya GKJ Ngesrep ?

3. Siapa saja yang menjadi pendeta di GKJ Ngesrep dari awal mula berdirinya gereja sampai sekarang?

4. Apa saja kegiatan yang dilakukan pada saat peribadatan?

5. Apa saja kegiatan dalam seminggu di GKJ Ngesrep ?

6. Bagaimana suasana jemaat pada saat mengikuti ibadah dan mengikuti nyanyian puji-pujian pada saat ibadah?

7. Materi lagu apa saja yang biasanya dibawakan oleh Pemandu Nyanyian Jemaat? 
8. Berapa jumlah jemaat yang ada di GKJ Ngesrep?

9. Apa saja persiapan yang dilakukan sebelum melaksanakan proses peribadatan?

10. Apa fungsi Pemandu Nyanyian Jemaat pada saat peribadatan?

11. Apa pengaruhnya Pemandu Nyanyian Jemaat bagi peribadatan yang dilakukan di GKJ Ngesrep?

\section{B. Ketua Majelis GKJ Ngesrep}

1. Nama Lengkap $\quad$ : Stefanus Sugiman

2. Jenis Kelamin $\quad$ : Laki-laki

3. Usia $: 61$ th

4. Pendidikan $\quad: S 1$

5. Pekerjaan : Pensiun PNS Guru

1. Bagaimana kegiatan majelis pada saat peribadatan?

2. Apa saja kegiatan dalam seminggu di GKJ Ngesrep ?

3. Bagaimana suasana jemaat pada saat mengikuti ibadah dan mengikuti nyanyian puji-pujian pada saat ibadah?

4. Materi lagu apa saja yang biasanya dibawakan oleh Pemandu Nyanyian Jemaat?

5. Berapa jumlah jemaat yang ada di GKJ Ngesrep?

6. Bagaimana pandangan majelis terhadap Pemandu Nyanyian Jemaat di GKJ Ngesrep?

7. Hal apa saja yag dilakukan majelis pada saat peribadatan?

8. Bagaimana perkembangan majelis di GKJ Ngesrep ? 
9. Apa yang anda ketahui tentang Pemandu Nyanyian Jemaat di GKJ Ngesrep?

10. Apa peran Pemandu Nyanyian Jemaat dalam peribadatan?

11. Bagaimana struktur organisasi di GKJ Ngesrep?

12. Bagaimana profil dari GKJ Ngesrep ?

\section{Ketua II Seni Budaya GKJ Ngesrep}

1. Nama Lengkap : Nina Woelan Suebroto

2. Jenis Kelamin : Perempuan

3. Usia : 51 th

4. Pendidikan : S2

5. Pekerjaan : Dosen

1. Bagaimana struktur organisasi KSB di GKJ Ngesrep ?

2. Siapa saja anggota dari KSB ?

3. Materi apa saja yang dibawakan pada saat peribadatan?

4. Apa saja kegiatan yang dilakukan Pemandu Nyanyian Jemaat pada saat peribadatan?

5. Apakah ada perbedaan Pemandu Nyanyian Jemaat yang terdahuu dengan Pemandu Nyanyian Jemaat yang skarang??

6. Bagaimana suasana jemaat pada saat mengikuti ibadah dan mengikuti nyanyian puji-pujian pada saat ibadah?

7. Apa fungsi Pemandu Nyanyian Jemaat pada saat peribadatn? 
8. Apa pengaruhnya Pemandu Nyanyian Jemaat bagi peribadatan yang dilakukan di GKJ Ngesrep?

9. Siapakah yang boleh menjadi petugas Pemandu Nyanyian Jemaat untuk ibadah?

10. Hal apa saja yang harus dilakukan Pemandu Nyanyian Jemaat dan hal apa saja yang tidak boleh dilakukan oleh Pemandu Nyanyian Jemaat pada saat peribadatan?

11. Bagaimana pendapat ibu atas perkembangan Pemandu Nyanyian Jemaat pada saat ini?

12. Apa saja tema yang boleh dibawakan Pemandu Nyanyian Jemaat pada saat ibadah?

\section{Ketua I KBS GKJ Ngesrep}

1. Nama Lengkap $\quad$ : Maria Denok Bkti Agustiningrum, M.Pd

2. Jenis Kelamin $\quad$ : Perempuan

3. Usia : 39 th

4. Pendidikan : Mahasiswa S3 Pendidikan Seni

5. Pekerjaan : Dosen

1. Bagaimana bentuk vokal yang anda nyanyikan dalam peribadatan?

1. Bagaimanakan jenis suara yang anda nyanyikan?

2. Bagaimana suasana jemaat pada saat mengikuti ibadah dan mengikuti nyanyian puji-pujian pada saat ibadah?

3. Materi apa saja yang anda sering dinyanyikan pada saat ibadah?

4. Teknik vocal seperti apa yang dilatih? 
5. Siapa pelatih yang melatih Pemandu Nyanyian Jemaat?

6. Bagaimana teknik pernafasan pada saat anda bernyanyi?

7. Bagaimana teknik artikulasi pada saat anda bernyanyi?

8. Bagaimana teknik resonansi pada saat anda bernyanyi?

9. Bagaimana teknik phrasering pada saat anda bernyanyi?

10. Bagaimana teknik ekspresi pada saat anda bernyanyi?

11. Kapan dan dimana latihan dalam seminggu?

12. Persiapan apa saja yang dilakukan Pemandu Nyanyian Jemaat sebelum melaksanakan ibadah?

13. Musik iringan yang digunakan apa?

14. Dalam peribadatan ada istilah procantor dalam Pemandu Nyanyian Jemaat, apa yang anda ketahui tentang istilah tersebut?

15. Apa sajakah syarat untuk bisa menjadi procantor?

16. Apa peran procantor dalam peribadatan?

17. Apa saja yang harus dilakukan oleh seorang procntor pada saat bertugas dalam ibadah?

18. Selain istilah dari procantor, ada istilah lain yaitu cantoria, apa yang anda ketahui tentang istilah cantoria tersebut?

19. Apa sajakah syarat untuk menjadi cantoria?

20. Apa peran cantoria dalam peribadatan?

21. Apa saja yang harus dilakukan oleh seorang cantoria pada saat bertugas dalam ibadah?

22. Apa pengaruh procantor atau cantoria untuk peribadatan? 
23. Berapa jumlah anggota yang bertugas menjadi procantor atau cantoria dalam ibadah?

24. Pada bagian apakah procantor dan cantoria bertugas memandu pujian?

\section{E. Anggota KBS GKJ Ngesrep}

1. Nama Lengkap $\quad$ : Supriyani

2. Jenis Kelamin : Wanita

3. Usia $: 55$ th

4. Pendidikan : SLTA

5. Pekerjaan : Mengurus rumah tangga

1. Bagaimana bentuk vokal yang anda nyanyikan dalam peribadatan?

2. Bagaimanakan jenis suara yang anda nyanyikan?

3. Bagaimana suasana jemaat pada saat mengikuti ibadah dan mengikuti nyanyian puji-pujian pada saat ibadah?

4. Materi apa saja yang anda sering dinyanyikan pada saat ibadah?

5. Teknik vocal seperti apa yang dilatih?

6. Siapa pelatih yang melatih Pemandu Nyanyian Jemaat?

7. Bagaimana teknik pernafasan pada saat anda bernyanyi?

8. Bagaimana teknik artikulasi pada saat anda bernyanyi?

9. Bagaimana teknik resonansi pada saat anda bernyanyi?

10. Bagaimana teknik phrasering pada saat anda bernyanyi?

11. Bagaimana teknik ekspresi pada saat anda bernyanyi?

12. Kapan dan dimana latihan dalam seminggu? 
13. Persiapan apa saja yang dilakukan Pemandu Nyanyian Jemaat sebelum melaksanakan ibadah?

14. Musik iringan yang digunakan apa?

15. Dalam peribadatan ada istilah procantor dalam Pemandu Nyanyian Jemaat, apa yang anda ketahui tentang istilah tersebut?

16. Apa sajakah syarat untuk bisa menjadi procantor?

17. Apa peran procantor dalam peribadatan?

18. Apa saja yang harus dilakukan oleh seorang procntor pada saat bertugas dalam ibadah?

19. Selain istilah dari procantor, ada istilah lain yaitu cantoria, apa yang anda ketahui tentang istilah cantoria tersebut?

20. Apa sajakah syarat untuk menjadi cantoria?

21. Apa peran cantoria dalam peribadatan?

22. Apa saja yang harus dilakukan oleh seorang cantoria pada saat bertugas dalam ibadah?

23. Apa pengaruh procantor atau cantoria untuk peribadatan?

24. Berapa jumlah anggota yang bertugas menjadi procantor atau cantoria dalam ibadah?

25. Pada bagian apakah procantor dan cantoria bertugas memandu pujian?

\section{F. Jemaat GKJ Ngesrep}

$\begin{array}{ll}\text { 1. Nama Lengkap } & \text { : Agus Nugroho } \\ \text { 2. Jenis Kelamin } & \text { : laki-laki }\end{array}$


3. Usia : 64th

4. Pendidikan

5. Pekerjaan
: S1

: Karyawan Swasta

1. Bagaimana bentuk vokal yang anda nyanyikan dalam peribadatan?

2. Bagaimanakan jenis suara yang anda nyanyikan ?

3. Bagaimana suasana jemaat pada saat mengikuti ibadah dan mengikuti nyanyian puji-pujian pada saat ibadah?

4. Materi apa saja yang anda sering dinyanyikan pada saat ibadah?

5. Teknik vocal seperti apa yang dilatih?

6. Siapa pelatih yang melatih Pemandu Nyanyian Jemaat?

7. Bagaimana teknik pernafasan pada saat anda bernyanyi?

8. Bagaimana teknik artikulasi pada saat anda bernyanyi?

9. Bagaimana teknik resonansi pada saat anda bernyanyi?

10. Bagaimana teknik phrasering pada saat anda bernyanyi?

11. Bagaimana teknik ekspresi pada saat anda bernyanyi?

12. Kapan dan dimana latihan dalam seminggu?

13. Persiapan apa saja yang dilakukan Pemandu Nyanyian Jemaat sebelum melaksanakan ibadah?

14. Musik iringan yang digunakan apa?

15. Dalam peribadatan ada istilah procantor dalam Pemandu Nyanyian Jemaat, apa yang anda ketahui tentang istilah tersebut?

16. Apa sajakah syarat untuk bisa menjadi procantor?

17. Apa peran procantor dalam peribadatan? 
18. Apa saja yang harus dilakukan oleh seorang procntor pada saat bertugas dalam ibadah?

19. Selain istilah dari procantor, ada istilah lain yaitu cantoria, apa yang anda ketahui tentang istilah cantoria tersebut?

20. Apa sajakah syarat untuk menjadi cantoria?

21. Apa peran cantoria dalam peribadatan?

22. Apa saja yang harus dilakukan oleh seorang cantoria pada saat bertugas dalam ibadah?

23. Apa pengaruh procantor atau cantoria untuk peribadatan?

24. Berapa jumlah anggota yang bertugas menjadi procantor atau cantoria dalam ibadah? 


\section{TRANSKIP HASIL WAWANCARA}

\section{WAWANCARA}

Pokok-pokok wawancara ditunjukan kepada ketua Pemandu Nyanyian Jemaat GKJ Ngesrep, Anggota Pemandu Nyanyian Jemaat, Pendeta, Majelis, Jemaat di GKJ Ngesrep Kota Semarang. Data Lengkap informan Yang akan Di wawancarai Sebagai Berikut:

\section{Pendeta GKJ Ngesrep}
a. Nama Lengkap $\quad$ : Pdt. Iskak Dodie Irawan, S. Si
b. Jenis Kelamin : laki-laki
c. Usia : 48 th
d. Pendidikan : S.Th
e. Pekerjaan : Pendeta

Transkip wawancara

\section{Pertanyaan :}

a. Apa saja kegiatan yang dilakukan pada saat peribadatan?

\section{Jawaban :}

Yang dilakukan sesuai dengan tata ibadah Gereja Kristen Jawa, yang masih menggunakkan liturgi

\section{Pertanyaan :}

b. Apa saja kegiatan dalam seminggu di GKJ Ngesrep ?

\section{Jawaban :}

Kegiatan di GKJ Ngesrep itu bisa dilihat di warta gereja, disitu sudah dijadwal bahwa setiap hari selasa ada rapat majelis di gedung greja, hari selasa dan kamis 
untuk kursus musik yaitu organ, gitar dan bass yang tempatnya juga d gedung gereja, kemudian ada pemahaman alkitab wilayah yang dilaksanakan setiap hari rabu di masing-masing wilayah sesuai jadwal ada wilayah banyumanik, wilayang ngesrep, wilayah srondol. Untuk setiap hari jumat itu ada persekutuan doa pagi di gedung greja pukul 5 pagi, kemudian jumat malamnya ada latihan koor pukul 7 malam, untuk hari sabtu di gedung gereja ada katekisasi setiap pukul 6 sore.

\section{Pertanyaan :}

c. Bagaimana suasana jemaat pada saat mengikuti ibadah dan mengikuti nyanyian puji-pujian pada saat ibadah?

\section{Jawaban :}

Suasananya kusyuk tentunya dan bisa mengikuti ibadah dengan baik

\section{Pertanyaan :}

d. Materi lagu apa saja yang biasanya dibawakan oleh Pemandu Nyanyian Jemaat?

\section{Jawaban :}

Untuk materi lagu biasanya kami lebih sring mengambil dari kidung jemaat atau biasanya disingkat KJ, namun kami juga ada buku pujian lan yang kami gunakan. Gereja kami kan gereja kristen jawa, jadi untuk lagu pujian yang berbahasa jawa kami ambil Kidung Pasamuwan Kristen (KPK), juga untuk lagu pujian yang berbahasa indonesia selain KJ juga ada NKB, PKJ.

\section{Pertanyaan :}

e. Apa saja persiapan yang dilakukan sebelum melaksanakan proses peribadatan? 


\section{Jawaban :}

Sebelumnya kami yaitu para majelis, pendeta, singer, pemusik, dan petugas LCD berkumpul di ruang konsistori untuk berdoa terlebih dahulu sebelum menjalankan pelayanan ibadah, setelah berdoa kami langsung menempatkan diri di masingmasing tugas

\section{Pertanyaan :}

f. Apa fungsi Pemandu Nyanyian Jemaat pada saat peribadatan?

\section{Jawaban :}

Membantu pendeta, majelis, dan jemaat dalam melakukan perjumpaan dengan Tuhan melalui Pujian

\section{Pertanyaan :}

g. Apa pengaruhnya Pemandu Nyanyian Jemaat bagi peribadatan yang dilakukan di GKJ Ngesrep?

\section{Jawaban :}

Pengaruhnya sangat besar mbak, membuat semua jemaat mengerti dan memahami lagu yang dinyanyikan sehingga tidak ragu-ragu dalam beranyanyi karna sudah ada yang mimpin atau bisa disebut mbak bella tadi Pemandu Nyanyian Jemaat.

\section{Ketua Majelis GKJ Ngesrep}
a. Nama Lengkap : Stefanus Sugiman
b. Jenis Kelamin : Laki-laki
c. Usia : 61 th
d. Pendidikan $\quad:$ S1
e. Pekerjaan : Pensiun PNS Guru 
Transkip wawancara

\section{Pertanyaan :}

a. Bagaimana kegiatan majelis pada saat peribadatan?

\section{Jawaban :}

Ya mbak bella, kegiatan majelis melayani jemaat saat beribadah seperti mengedarkan kantong persembahan, bertugas sebagai pembaca liturgi, memimpin doa, membacakan injil Tuhan sebelum pada inti firman yang akan dibacakan bapak pendeta

\section{Pertanyaan :}

b. Apa saja kegiatan dalam seminggu di GKJ Ngesrep ?

\section{Jawaban :}

Puji Tuhan kegiatan kami dalam seminggu selalu terlaksana dengan baik. Hari senin tidak ada kegiatan, selasa itu les organ tiap sore, hari rabu itu ada pendalaman alkitab wilayah yang dilaksanakan di rumah-rumah jemaat tiap wilayah sesuai jadwal yang sudah dibuat, kemudian kalo hari kamis itu ada les gitar dan drum, untuk kursus musik ini memang dari greja mbak jadi dana les dari greja mbak untuk menghasilkan bibit-bibit pemusik selanjutnya di GJKJ Ngesrep ini, ya lanjut ya mbak, hari jumaat itu pagi jam 5 pagi ada persekutuan doa pagi di greja, jadi buat semua anggota jemaat boleh hadir tidak ada batasan umur, nah malam harinya jam 7 itu ada latihan koor rutin jemaat GKJ Ngesrep, biasanya ibuibu dan bapak-bapak mbak juga keluarga muda, kalok hari sabtu sendiri ada katekisasi tiap sore yang ngajar atau yang memberikan materi katekisasi itu bapak pendeta. 


\section{Pertanyaan :}

c. Bagaimana suasana jemaat pada saat mengikuti ibadah dan mengikuti nyanyian puji-pujian pada saat ibadah?

\section{Jawaban :}

Nah ini mbak terkadang jemaat suka mencari tempo sendiri kalau bernyanyi sehingga Pemandu Nyanyian Jemaat maupun pemusik juga mengikuti tempo jemaat. Seharusnya jemaat mengikuti Pemandu Nyanyian Jemaat dan pemusik namun sering kali pemusik dan Pemandu Nyanyian Jemaat kalah dengan jemaat.

\section{Pertanyaan :}

d. Materi lagu apa saja yang biasanya dibawakan oleh Pemandu Nyanyian Jemaat ?

\section{Jawaban :}

Yang biasanya dibawakan itu diambil dari kidung jemaat mbak karana di kidung jemaat sudah ada semua dan biasanya juga sudah dari dulu ambilnya dikidung

\section{Pertanyaan :}

e. Bagaimana pandangan majelis terhadap Pemandu Nyanyian Jemaat di GKJ Ngesrep?

\section{Jawaban :}

Kalau menurut saya pribadi Pemandu Nyanyian Jemaat di GKJ Ngesrep suaranya bagus-bagus dan mayoritas juga anggota dari paduan suara GKJ Ngesrep, Cuma kadang itu beberapa ada yang suka salah waktu nyanyi di ibadah dan mungkin kurang latihan menurut saya mbak

\section{Pertanyaan :}


f. Hal apa saja yag dilakukan majelis pada saat peribadatan?

\section{Jawaban :}

Melayani jemaat yaitu berdoa, menjadi pembaca liturgi, mengedarkan kantong prsembahan, membacakan injil.

\section{Pertanyaan :}

g. Apa yang anda ketahui tentang Pemandu Nyanyian Jemaat di GKJ Ngesrep? Apa peran Pemandu Nyanyian Jemaat dalam peribadatan?

\section{Jawaban :}

Pemandu Nyanyian Jemaat itu orang yang bertugas sebagai penyanyi di gereja yang memandu dalam pelayanan
3. Ketua I Komisi Seni Budaya (KSB) GKJ Ngesrep
a. Nama Lengkap : Maria Denok Bkti Agustiningrum, M.Pd
b. Jenis Kelamin : Perempuan
c. Usia : 39th
d. Pendidikan : Mahasiswa S3 Pendidikan Seni
e. Pekerjaan : Dosen

Transkip wawancara

\section{Pertanyaan :}

a. Bagaimana bentuk vokal dan jenis suara PEMANDU NYANYIAN JEMAAT ketika benyanyi dalam peribadatan?

\section{Jawaban :}

Dalam bernyanyi menjadi petugas Pemandu Nyanyian Jemaat di GKJ Ngesrep kami berangotakan 3 orang dengan karakter suara yang berbeda-beda, teknik 
bernyanyi yang kami lakukan kami menyadari bahwa masih banyak kekurangan dalam bernyanyi yang baik dan benar hal tersebut dikarnakan jadwal latihan yang kurang dan pemahaman lagu yang kurang, dan tenaga pengajar atau pelatih tidak ada.

\section{Pertanyaan :}

b. Bagaimana suasana jemaat pada saat mengikuti ibadah dan mengikuti nyanyian puji-pujian pada saat ibadah?

\section{Jawaban :}

Suasananya baik mbak semua jemaat khusuk dan fokus pada peribadatan

\section{Pertanyaan :}

c. Materi apa saja yang anda sering dinyanyikan pada saat ibadah?

\section{Jawaban :}

Kami memakai buku Kidung Jemaat biasanya, namun ada buku lain juga yang kami gunakan selain kidung jemaat yaitu buku NKB. Kalau ibadah menggunakan bahasa jawa kami memakai buku KPK. Yang isnya lagu-lagu untuk peribadatan

\section{Pertanyaan :}

d. Bagaimana Teknik vocal Pemandu Nyanyian Jemaat saat ini dan ada berapa orang yang bertugas?

\section{Jawaban :}

Dalam bernyanyi menjadi petugas Pemandu Nyanyian Jemaat di GKJ Ngesrep kami berangotakan 3 orang dengan karakter suara yang berbeda-beda, teknik bernyanyi yang kami lakukan kami menyadari bahwa masih banyak kekurangan dalam bernyanyi yang baik dan benar hal tersebut dikarnakan jadwal latihan yang 
kurang dan pemahaman lagu yang kurang, dan tenaga pengajar atau pelatih tidak ada.

\section{Pertanyaan :}

e. Siapa pelatih yang melatih Pemandu Nyanyian Jemaat?

\section{Jawaban :}

Tidak ada mbak, kami berlatih sendiri selama ini kami berlatih sendiri itupun latihannya gak terlalu rutin

\section{Pertanyaan :}

f. Bagaimana teknik pernafasan pada saat anda bernyanyi?

\section{Jawaban :}

Beberapa sudah ada yang baik. Kalau saya sendiri masih pendek nafasnya, tapi saya sudah memakai nafas diafragma mbak

\section{Pertanyaan :}

g. Bagaimana teknik artikulasi pada saat anda bernyanyi?

\section{Jawaban :}

Kalau artikulasi saya sudah banyak yang pahah mbak karna nyanyikan jelas to mbak biar bagus supaya nggak dikira nggremeng mbak.

\section{Pertanyaan :}

h. Bagaimana teknik resonansi pada saat anda bernyanyi?

\section{Jawaban :}

Beberapa masih banyak yang belom lebar mbak, jadi masih pelan-pelan suaranya belom dikeluarkan. Yang lantag ya beberapa belum seluruh

\section{Pertanyaan :}


i. Bagaimana teknik phrasering pada saat anda bernyanyi?

\section{Jawaban :}

Lha iki, kami tu sering pemenggalan yang kadang lupa ngliat tanda petik atas itu mbak karna kami nek lagunya susah ya fokusnya ke nadanya. Kadang-kadang bingung

\section{Pertanyaan :}

j. Bagaimana teknik ekspresi pada saat anda bernyanyi?

\section{Jawaban :}

Kalau ekspresi kami selalu bisa mengikuti sesuai lagunya itu ceritanya apa mbak karna itu sangat penting dalam penghayatan lagu

\section{Pertanyaan :}

k. Kapan dan dimana latihan dalam seminggu?

\section{Jawaban :}

Kami menyesuaikan pemusiknya bisanya kapan, kami ngikup pemusik mbak. Tapi biasanya sabtu sore di gedung greja.

\section{Pertanyaan :}

1. Bagaimana Bentuk penyajian yang dilakukan Pemandu Nyanyian Jemaat sebelum melaksanakan ibadah?

\section{Jawaban :}

Di dalam bentuk penyajian Pemandu Nyanyian Jemaat proses peribadatan memang mempunyai strukturnya adalah sebelum memulai ibadah Pemandu Nyanyian Jemaat berkumpul diruang Konsisturi untuk berdoa bersama dengan bapak Pendeta setelah itu kami kembali ke tempat kami bertugas dan 
mempersiapkan lagu pertama yang akan dinyanyikan pada pembukaan ibadah, setelah itu bel berbunyi sekali baru kami langsung berdiri dan mulai menyanyi lagu pembukaan mbak.

\section{Pertanyaan :}

m. Musik iringan yang digunakan apa?

\section{Jawaban :}

Organ mbak. Ada beberapa organis yang sudah memakai musik style dari organ itu.

\section{Pertanyaan :}

n. Dalam peribadatan ada istilah procantor dalam Pemandu Nyanyian Jemaat, apa yang anda ketahui tentang istilah tersebut?

\section{Jawaban :}

Seseorang yang memimpin pujian dalam peribadatan, atau biasanya kami yang memberi aba-aba kepada singer lain dan petugas musik bahwa setelah ini lagu apa, nadanya seberapa, trus nyanyinya berapa bait.

\section{Pertanyaan :}

o. Apa sajakah syarat untuk bisa menjadi procantor?

\section{Jawaban :}

Wah kalok pakai syrat-syaratan nanti pada lari semua dan ndak ada yang mau tugas mbak. Kalok kami siapaun yang mau menjadi procantor atau cantoria silahkan karna kami tujuannya melayani Tuhan, dan bagi yang belum bisa itu kita bisa belajar sama-sama.

\section{Pertanyaan :}


p. Apa saja yang harus dilakukan oleh seorang procntor pada saat bertugas dalam ibadah?

\section{Jawaban :}

Ya itu mbak untuk mengingatkan singer lain dan pemusik.

\section{Pertanyaan :}

q. Selain istilah dari procantor, ada istilah lain yaitu cantoria, apa yang anda ketahui tentang istilah cantoria tersebut?

\section{Jawaban :}

Singer lain, atau Pemandu Nyanyian Jemaat lain yang membantu procantor dalam bernyanyi

\section{Pertanyaan:}

r. Apa sajakah syarat untuk menjadi cantoria?

\section{Jawaban :}

Masih tetap sama mbak, kami tidak ada syarat-saratan.

\section{Pertanyaan :}

s. Apa saja yang harus dilakukan oleh seorang cantoria pada saat bertugas dalam ibadah?

\section{Jawaban :}

Membantu procantor bernyanyi dengan baik dan benar

\section{Pertanyaan :}

t. Berapa jumlah anggota yang bertugas menjadi procantor atau cantoria dalam ibadah?

\section{Jawaban :}


Banyak mbak ada tiga orang yang betugas menjadi procantor atau cantoria kadang-kadang juga lebih
4. Ketua II Komisi Seni Budaya (KSB) GKJ Ngesrep
a. Nama Lengkap : Nina Woelan Suebroto
b. Jenis Kelamin : Perempuan
c. Usia : 51 th
d. Pendidikan : $\mathrm{S} 2$
e. Pekerjaan : Dosen

Transkip wawancara

\section{Petanyaan :}

a. Bagaimana struktur organisasi KSB di GKJ Ngesrep ?

\section{Jawaban :}

Struktur organisani atau kepengurusan KSB GKJ Ngesrep ketua1 nya adalah ibu pendeta ibu denok, ketua kedua saya sendiri,kemudian untuk sekretaris juga ada dua ibu agus dan bu rini, sedangkan bendaharanya juga ada dua ibu joko dan ibu sri, untuk anggotanya sendiri kami hanya ada 5 namun kami juga menjadwalkan bagi para jemaat yang bersedia menjadi singer dalam ibadah. Anggota inti ada ibu supriyani, ibu tri iswanto, ibu ruth, mas rian, dan mas hary.

\section{Pertanyaan :}

b. Siapa saja anggota dari KSB ?

\section{Jawaban :}

Anggota inti ada ibu supriyani, ibu tri iswanto, ibu ruth, mas rian, dan mas hary. Dan sama seperti yang saya bilang tadi mbak bahwa untuk anggota yang lain itu 
kita menjadwalkan jemaat yang bersedia menjadi singer/Pemandu Nyanyian Jemaat dalam ibadah.

\section{Petanyaan :}

c. Materi apa saja yang dibawakan pada saat peribadatan?

\section{Jawaban :}

Kami paling sering membawakan materi dari kidung jemaat karena dalam satu bulan itu ad 4 kali ibadah. Minggu pertama, kedua dan keempat kami memakai bahsa indonesia adi kami paling sering pakai kidung jemaat. Pada minggu ketiga kami pakek bahasa jawa, nah kalau bahasa jawa kami memakai Kidung pasamuan kristen.

\section{Pertanyaan :}

d. Apa saja kegiatan yang dilakukan Pemandu Nyanyian Jemaat pada saat peribadatan?

\section{Jawaban :}

Sebelum pelayanan kami berdoa dulu diruang konsistori setelah itu kami ke tempat Pemandu Nyanyian Jemaat bertugas menunggu bel berbunyi kemudian kami berdiri menyanyikan lagu pembukaan, setelah itu nyanyian pujian, nyanyian penyesalan, nyanyian kesanggupan, nyanyian persembahan, nyanyian pengutusan, dan yag terakhir adalah nyanyian pengutusan.

\section{Pertanyaan :}

e. Bagaimana suasana jemaat pada saat mengikuti ibadah dan mengikut nyanyian puji- pujian pada saat ibadah?

\section{Jawaban :}


Suasananya bagaimana ya? Emmm ya jemaat bisa mengikuti dengan baik

\section{Pertanyaan :}

f. Apa fungsi Pemandu Nyanyian Jemaat pada saat peribadatn?

\section{Jawaban :}

Fungsinya itu untuk membantu jemaat dalam menaikkan nyanyian-nyanyian pada saat ibadah sehingga bisa menghayati lebih sungguh ketika bernyanyi waktu melakukan perjumpaan dengan Tuhan.

\section{Pertanyaan :}

g. Apa pengaruhnya Pemandu Nyanyian Jemaat bagi peribadatan yang dilakukan di GKJ Ngesrep?

\section{Jawaban :}

Iya itu tadi mbak pengaruhnya bbagi jemaat bisa terbantu dalam melakukan perjumpaan dengan Tuhan dalam ibadah lewat lagu, jadi ketika jemaat tidak mengerti lagunya, kami Pemandu Nyanyian Jemaat kan sudah belajar sudah latihan jadi kami bisa menuntun jemaat menyanyikan lagu pujian itu mbak

\section{Pertanyaan :}

h. Siapakah yang boleh menjadi petugas Pemandu Nyanyian Jemaat untuk ibadah?

\section{Jawaban :}

Ohhh kalau itu siapa saja mbak tidak ada batasan umur. Tapi seringnya jemaat yang sudah dewasa atau tua

\section{Pertanyaan :}


i. Hal apa saja yang harus dilakukan Pemandu Nyanyian Jemaat dan hal apa saja yang tidak boleh dilakukan oleh Pemandu Nyanyian Jemaat pada saat peribadatan?

\section{Jawaban :}

Bernyanyi tidak boleh keras-kerasan atau saling menonjol. Karna kan kami Pemandu Nyanyian Jemaat ada 3 orang jadi kita harus harmonis suaranya. Yang haru dilakukan menyanyi dengan benar dan baik serta menhayati lagunya dengan baik.

\section{Pertanyaan :}

j. Bagaimana pendapat ibu atas perkembangan Pemandu Nyanyian Jemaat pada saat ini?

\section{Jawaban :}

Yaa gimana ya mbak. Pemandu Nyanyian Jemaat di GKJ Ngesrep cukup baik perkembangannya, tapi tu mungkin kadang kurang latihan ya sehingga pada saat bernyanyi di ibadah kadang masih banyak beberapa ragu dengan materi lagunya.

\section{Pertanyaan :}

K. Apa saja tema yang boleh dibawakan Pemandu Nyanyian Jemaat pada saat ibadah?

\section{Jawaban :}

Temanya lagu disesuaikan dengan tema firman pada saat ibadah minggu dan pengambilan lagu tersebut biasanya dari pusat atau bapak pendeta sendiri.

\section{Petanyaan :}

L. Bagaimana teknik pernafasan Pemandu Nyanyian Jemaat pada saat bertugas? 


\section{Jawaban :}

Anggota petugas Pemandu Nyanyian Jemaat masi sangat kurang dalam proses latihannya apalagi untuk berlatih teknik pernafasan saya melihat proses latihan mereka hanya dilakukan pada saat sebelum tampil dengan berlatih secara sederhana baik berlatih vokal maupun teknik pernafasan untuk bernyanyinya.

\section{Pertanyaan :}

m. Bagaimanakah teknik resonansi Pemandu Nyanyian Jemaat pada saat bertugas?

\section{Jawaban :}

Ya karna kami kalo bertugas itu bertiga, tapi karna orangnya yang berbeda-beda setiap minggunya jadi kadang kami kesusahan buat menyamakan suaranya, karena suaranya berbeda-beda, biasanya yang bertugas bisa suaranya yang tinggitinggi semua, ada juga yang bertugas suaranya rendah semua, atau ada juga yang campur ada yang tinggi, ada rendah, jadi kadang kami kesusahan menentukan nada dasar.
5. Anggota Komisi Seni Budaya (KSB) GKJ Ngesrep
a. Nama Lengkap : Supriyani
b. Jenis Kelamin : Perempuan
c. Usia :55 th
d. Pendidikan : SLTA
e. Pekerjaan : Mengurus rumah tangga

Transkip wawancara 


\section{Pertanyaan :}

a) Bagaimana bentuk vokal yang anda nyanyikan dalam peribadatan?

\section{Jawaban :}

Bentuknya trio mbak

\section{Pertanyaan :}

b) Bagaimanakan jenis suara yang anda nyanyikan?

\section{Jawaban :}

Jenis suara saya sopran karna saya di tim paduan suara GKJ Ngesrep jadi sopran, kalok nyanyi kecendek.en opo kuwi jenenge, kerendahan nadane ki susah mbak malahan

\section{Pertanyaan :}

c) Bagaimana suasana jemaat pada saat mengikuti ibadah dan mengikuti nyanyian puji-pujian pada saat ibadah?

\section{Jawaban :}

Kadang sok nyarik tempo sendiri mbak jemaatnya, makanya saya harus bisa memberikan bantuan ke jemaat biar ndak lari temponya

\section{Pertanyaan :}

d) Materi apa saja yang anda sering dinyanyikan pada saat ibadah?

\section{Jawaban :}

Materinya dari kidung jemaat mbak paling sering

\section{Petanyaan :}

e) Teknik vokal seperti apa yang dilatih?

\section{Jawaban :}


Kami tidak ada pelatihan-pelatihan gitu mbak wong ndak ada pelatihnya, jadi yo nyanyi yang penting bener nadanya sama temponya itu yang masih kesulitan, beberapa singer/Pemandu Nyanyian Jemaat itu masih banyak yang temponya ikuikutan jemaat jadi lendet

\section{Pertanyaan :}

f) Siapa pelatih yang melatih Pemandu Nyanyian Jemaat?

\section{Jawaban :}

Tidak ada mbak, kami latiha sendiri

\section{Pertanyaan :}

g) Bagaimana teknik pernafasan pada saat anda bernyanyi?

\section{Jawaban :}

Kalau saya sendiri sudah bisa memakai nafas diafragma mbak, karna saya dapat pelatihan nafas diafragma itu dari pelatih paduan suara

\section{Pertanyaan :}

h) Bagaimana teknik artikulasi pada saat anda bernyanyi?

\section{Jawaban :}

Kalok saya artikulasi jelas nomer satu karna kalok artikulasi ndk jelas penyampaian lagunya jadi tidak tersampai mbak

\section{Pertanyaan :}

i) Bagaimana teknik resonansi pada saat anda bernyanyi?

\section{Jawaban :}

Resonansi itu kan suara kudu kenceng to mbak? Nah nek iku aku sebenernya sudah kenceng mung kan nyanyinya bertiga trus ndak boleh keras sendiri to mbak. 


\section{Pertanyaan :}

j) Bagaimana teknik phrasering pada saat anda bernyanyi?

\section{Jawaban :}

Pemenggalan kata itu yang kadang agak susah mbak pas nyanyi lagu panjang cepet nah kadang nyolong-nyolong nafas ditengah-tengah. Karan gak sampai

\section{Pertanyaan :}

k) Bagaimana teknik ekspresi pada saat anda bernyanyi?

\section{Jawaban :}

Wah piye yo nek iku aku gak ngematke mbak bella. Kalok ekspresi lebih ke reflek sendiri sesuai lagunya mbak

\section{Pertanyaan :}

1) Kapan dan dimana latihan dalam seminggu?

\section{Jawaban :}

Latihan itu kami Pemandu Nyanyian Jemaat janjian bersama pemusiknya/ organisnya bisanya kapan mbak. Itu tergantung, tapi seringnya mepet mbak, misal tugas minggu pagi latihannya sabtu sore, atau tugas minggu sore lagiannya minggu pagi sehabis ibadah pagi

\section{Pertanyaan :}

m) Persiapan apa saja yang dilakukan Pemandu Nyanyian Jemaat sebelum melaksanakan ibadah?

\section{Jawaban :}

Kalok saya sudah terbiasa pemanasan sendiri mbak di perjalanan menuju motor, karna sampek greja tu ndak ada pemanasan bersama. Sebelum ibadah kami 
Pemandu Nyanyian Jemaat dan organis kumpul dulu diruang konsistori untuk berdoa bersama majelis dan pak pendeta

\section{Pertanyaan :}

n) Musik iringan yang digunakan apa?

\section{Jawaban :}

Musik iringan yang digunakan adalah organ mbak. Kadang ada orgais yang pakek musik apa iku jenenge, musik yang ada beat-beatnya mbak

\section{Pertanyaan :}

o) Dalam peribadatan ada istilah procantor dalam Pemandu Nyanyian Jemaat, apa yang anda ketahui tentang istilah tersebut?

\section{Jawaban :}

Wahh opo iku mbak, aku gak rerti mbak. Setauku petugas aja mbak namanya

\section{Pertanyaan :}

p) Apa sajakah syarat untuk bisa menjadi procantor?

\section{Jawaban :}

Kalok biasanya kami bertugas itu yang dimandati jadi pemimpin itu yang bisa membaca notasi dan memahami lagu trus bisa ngajari apa tadi mbak cantoria atau 2 Pemandu Nyanyian Jemaat yang lain

\section{Pertanyaan :}

q) Apa peran procantor dalam peribadatan?

\section{Jawaban :}

Membantu mengingatkan nada, lagu dan lirik saat akan bernyanyi, mengingatkan pemusik atau organis berapa bait yang akan dinyanyikan 


\section{Pertanyaan:}

r) Apa saja yang harus dilakukan oleh seorang procntor pada saat bertugas dalam ibadah?

\section{Jawaban :}

Ya itu tadi mbak sama kayak jawaban tadi

\section{Pertanyaan :}

s) Selain istilah dari procantor, ada istilah lain yaitu cantoria, apa yang anda ketahui tentang istilah cantoria tersebut?

\section{Jawaban :}

tadi dah dikasih tau mbak bella cantoriaa itu membantu procantor bernyanyi sehingga menjadi lebih bagus tugas mereka saling membantu mbak

\section{Pertanyaan :}

t) Apa sajakah syarat untuk menjadi cantoria?

\section{Jawaban :}

Tidak ada syaratnya mbak bela, disini itu yang penting kita mau berpelayanan untuk Tuhan tanpa paksaan dan pastinya mau belajar sama-sama

\section{Pertanyaan :}

u) Apa peran cantoria dalam peribadatan?

\section{Jawaban :}

Membantu procantor menyanyi dengan baik

\section{Pertanyaan :}

v) Apa saja yang harus dilakukan oleh seorang cantoria pada saat bertugas dalam ibadah? 


\section{Jawaban :}

Fokus taggung jawab sama lagunya masing-masing, jadi jangan ngandalke pemppimpnnya atau procantor tadi, atau jangan ngandelke yang bisa tok

\section{Pertanyaan :}

w) Apa pengaruh procantor atau cantoria untuk peribadatan?

\section{Jawaban :}

Jemaat jadi tahu yag harus dinyanyikan bait mana aja, trus jadi ikut tebawa nyanyinya keras

\section{Pertanyaan :}

$\mathrm{x})$ Berapa jumlah anggota yang bertugas menjadi procantor atau cantoria dalam ibadah?

\section{Jawaban :}

Anggita yang terjadwal banyak mbak, tapi untuk anggota inti mungkin sekitar 6 atau 7 mbak

\section{Pertanyaan :}

y) Pada bagian apakah procantor dan cantoria bertugas memandu pujian?

\section{Jawaban :}

Setelah ber berbunyi, trus setelah vontum salam, setelah pengakuan dosa, setelah berita anugerah, setelah persembahan, setelah firman, dan setelah berkat penutup.

\section{Pertanyaan :}

z) Ibu sendiri bertugas sebagai apa, dan apakah sudah menjalankan tugasnya dengan baik?

\section{Jawaban :}


Kalau saya tergantung dengan petugas Pemandu Nyanyian Jemaatnya nanti yang menentukan siapa yang akan jadi procantor dan cantoria, bisa jadi saya jadi procantor dan tugas berikutya bisa jadi cantoria. Iya saya kalau bertugas sebagai pembantu procantor kadang msih takut salah nada atau lirik jadi kadang kalo susah saya nyanyinya dijauhin miknya dan akhirnya saya gandul sama pemimpinnya procantor itu.
6. Jemaat GKJ Ngesrep
a. Nama Lengkap :Agus Nugroho
b. Jenis Kelamin : laki-laki
c. Usia : 64th
d. Pendidikan : S1
e. Pekerjaan : Karyawan Swasta

Transkip wawancara

\section{Pertanyaan :}

a. Bagaimana bentuk vokal/berapa orang yang menjadi petugas Pemandu Nyanyian Jemaat dalam peribadatan?

\section{Jawaban :}

Bertiga mbak yang nyanyi

\section{Pertanyaan :}

b. Bagaimana suasana jemaat pada saat mengikuti ibadah dan mengikuti nyanyian puji-pujian pada saat ibadah?

\section{Jawaban :}


Baik mbak semuanya mengikuti dengan baik

\section{Pertanyaan :}

c. Materi apa saja yang anda sering dinyanyikan pada saat ibadah?

\section{Jawaban :}

Kebanyakan dari kidung jemaat mbak soalnya kami dari minggu 1, 2, dan 4 menggunakan bahasa indonesia kalau ibadah, sedangkan minggu ke 3 bahasa jawa

\section{Pertanyaan :}

d. Bagaimana teknik pernafasan pada saat Pemandu Nyanyian Jemaat bernyanyi?

\section{Jawaban :}

Kadang masing terdengar ngos-ngossan dari beberapa singer

\section{Pertanyaan :}

e. Bagaimana teknik artikulasi pada saat Pemandu Nyanyian Jemaat bernyanyi?

\section{Jawaban :}

ya bisa dibilang saat Pemandu Nyanyian Jemaat menyanyikan puji-pujian sangat bagus pengucapan katanya, karena setiap saya beribadah saya bisa mendengarkan dengn khikmat ketika Pemandu Nyanyian Jemaat bernyanyi, dan sayapun bisa mengambil makna dari lagu yang dinyanyikan oleh Pemandu Nyanyian Jemaat dengan baik.

\section{Pertanyaan :}

f. Bagaimana teknik resonansi pada saat Pemandu Nyanyian Jemaat bernyanyi?

\section{Jawaban :}

Saya kurang paham tentang resonansi mbak.

\section{Pertanyaan :}


g. Bagaimana teknik ekspresi pada saat Pemandu Nyanyian Jemaat bernyanyi?

\section{Jawaban :}

Kspresinya sudah bagus menurut saya, karna ibadah jadi mungkin masing-masing Pemandu Nyanyian Jemaat mendalami lagunya ya.

\section{Pertanyaan :}

h. Musik iringan yang digunakan apa?

\section{Jawaban :}

Organ mbak, dari dulu 
CATATAN LAPANGAN

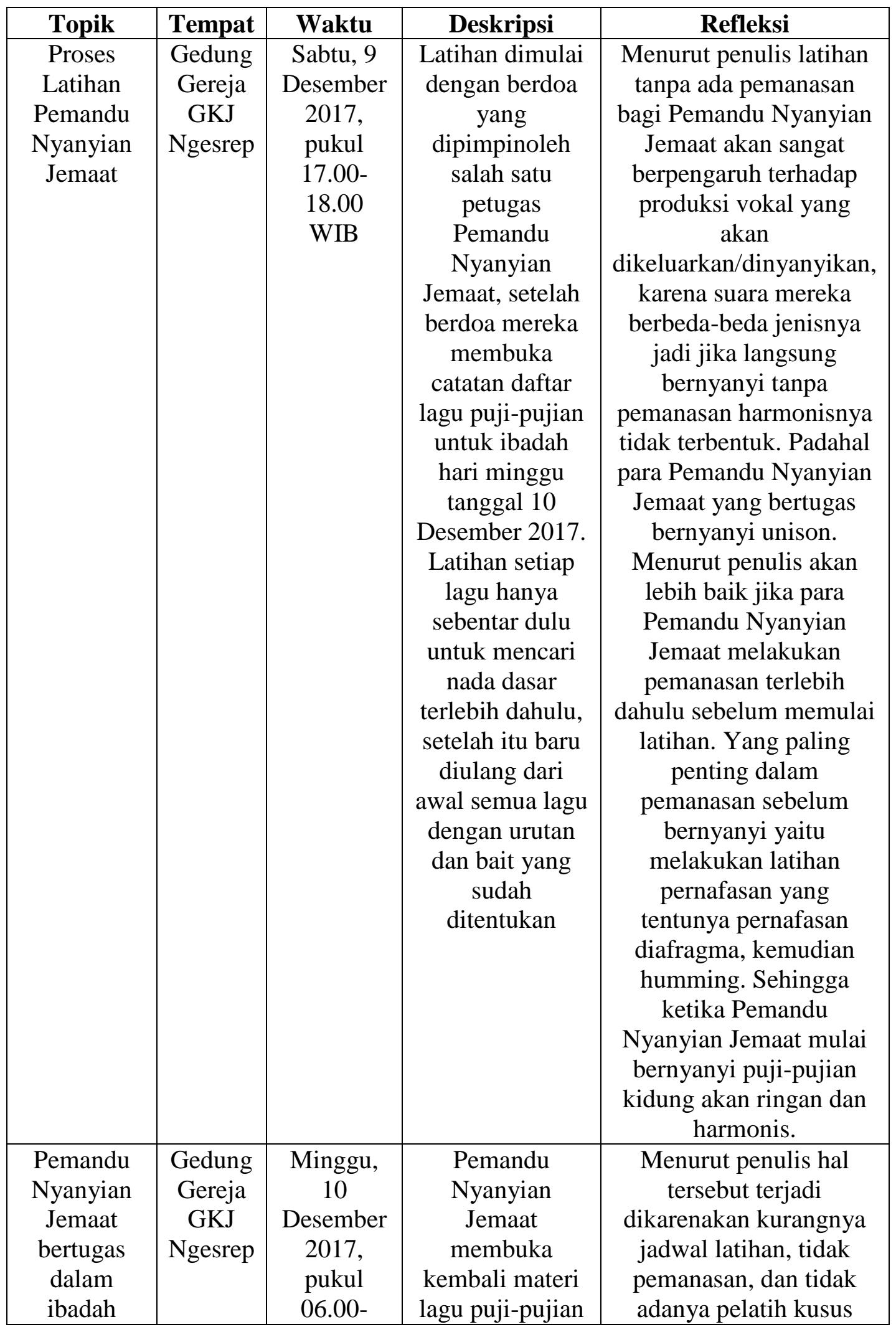




\begin{tabular}{|c|c|c|c|c|}
\hline minggu & & $\begin{array}{l}07.30 \\
\text { WIB }\end{array}$ & $\begin{array}{c}\text { yang akan } \\
\text { dinyanyikan } \\
\text { pada ibadah } \\
\text { pagi itu, namun } \\
\text { tanpa ada } \\
\text { pemanasan juga, } \\
\text { sehingga yang } \\
\text { terjadi suara } \\
\text { kurang menyatu/ } \\
\text { tdk harmonis } \\
\text { dan terkadan } \\
\text { beberapa lagu } \\
\text { lari dari tempo. } \\
\text { Selain lari dari } \\
\text { tempo, salah } \\
\text { satu Pemandu } \\
\text { Nyanyian } \\
\text { Jemaat ada yang } \\
\text { lupa dengan } \\
\text { nadanya. }\end{array}$ & $\begin{array}{l}\text { untuk Pemandu } \\
\text { Nyanyian Jemaat. }\end{array}$ \\
\hline $\begin{array}{l}\text { Pemandu } \\
\text { Nyanyian } \\
\text { Jemaat } \\
\text { Bertugas } \\
\text { dalam } \\
\text { ibadah } \\
\text { Minggu }\end{array}$ & $\begin{array}{l}\text { Gedung } \\
\text { Gereja } \\
\text { GKJ } \\
\text { Ngesrep }\end{array}$ & $\begin{array}{c}\text { Minggu, } 7 \\
\text { Januari } \\
2018, \\
\text { pukul } \\
06.00- \\
07.30 \\
\text { WIB }\end{array}$ & $\begin{array}{l}\text { Seperti biasa } \\
\text { Pemandu } \\
\text { Nyanyian } \\
\text { Jemaat berdoa } \\
\text { dan melihat } \\
\text { lagu-lagu } \\
\text { pujian. Namun } \\
\text { untuk kali ini } \\
\text { beberapa lagu } \\
\text { ada yang } \\
\text { menggunakan } \\
\text { style musik } \\
\text { sehingga } \\
\text { Pemandu } \\
\text { Nyanyian } \\
\text { Jemaat maupun } \\
\text { jemaat bisa } \\
\text { mengikuti } \\
\text { tempo dan tidak } \\
\text { lari dari tempo } \\
\text { seharusnya }\end{array}$ & $\begin{array}{l}\text { Menurut penulis, } \\
\text { Pemandu Nyanyian } \\
\text { Jemaat perlu dilatih } \\
\text { untuk teknik vokalnya } \\
\text { lebih dalam lagi. Seperti } \\
\text { yang saya lihat bahwa } \\
\text { kebanyakan faktor dari } \\
\text { larinya tempo berasal } \\
\text { dari pendeknya } \\
\text { pernafasan, salahnya } \\
\text { phrasering, serta } \\
\text { resonansi yang belom } \\
\text { lebar. }\end{array}$ \\
\hline
\end{tabular}




\section{FOTO-FOTO PENELITIAN}

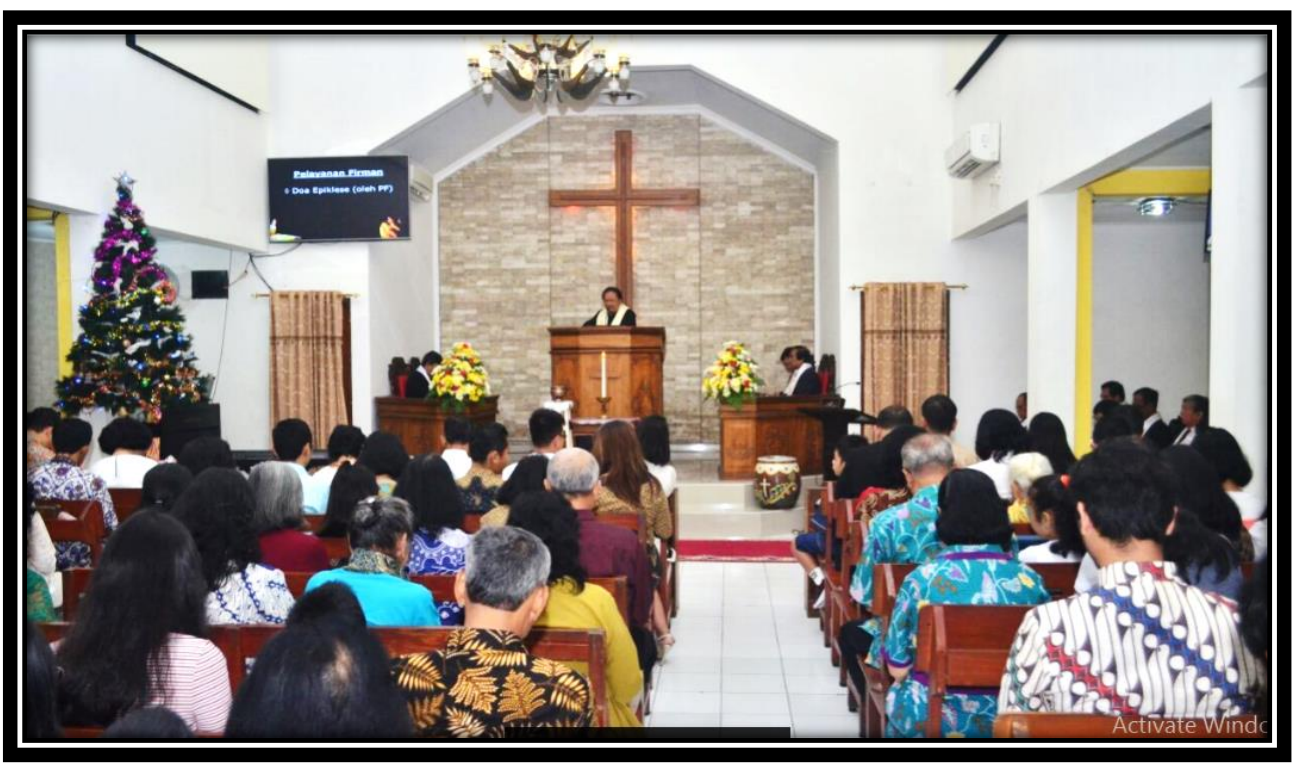

Gambar 1 Suasana Peribadatan di GKJ Ngesrep

(Sumber: Dokumen Bella Monica Paula, 2017)

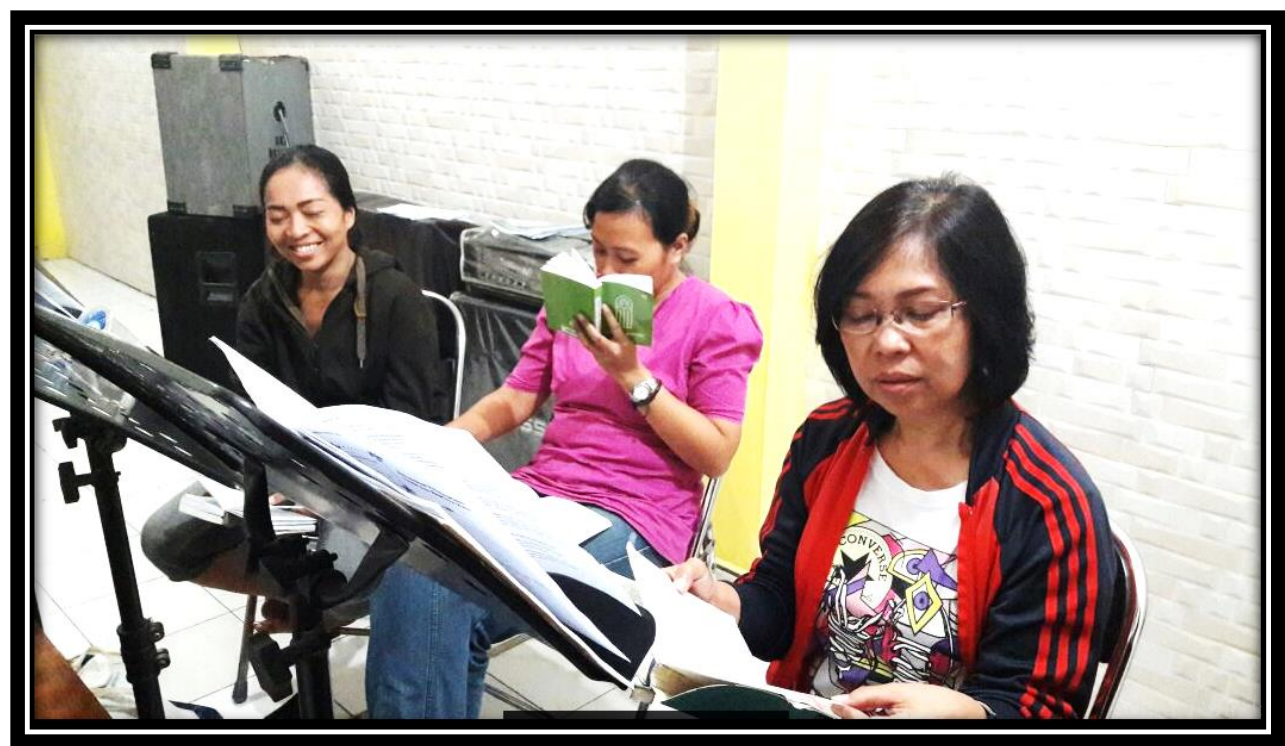

Gambar 2 Proses Latihan Pemandu Nyanyian Jemaat GKJ Ngesrep

(Sumber: Dokumen Bella Monica Paula, 2017) 


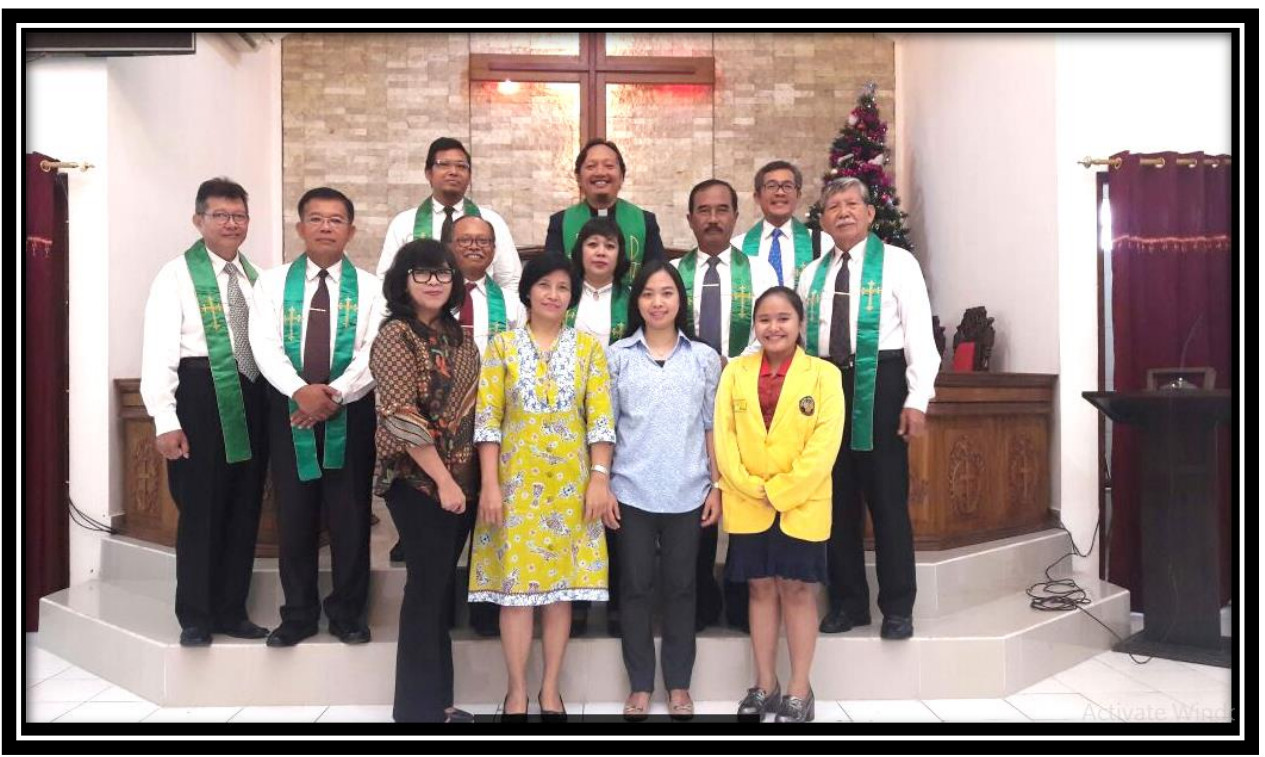

Gambar 3 Bersama Pendeta dan Perangkat di GKJ Ngesrep

(Sumber: Dokumen Bella Monica Paula, 2018)

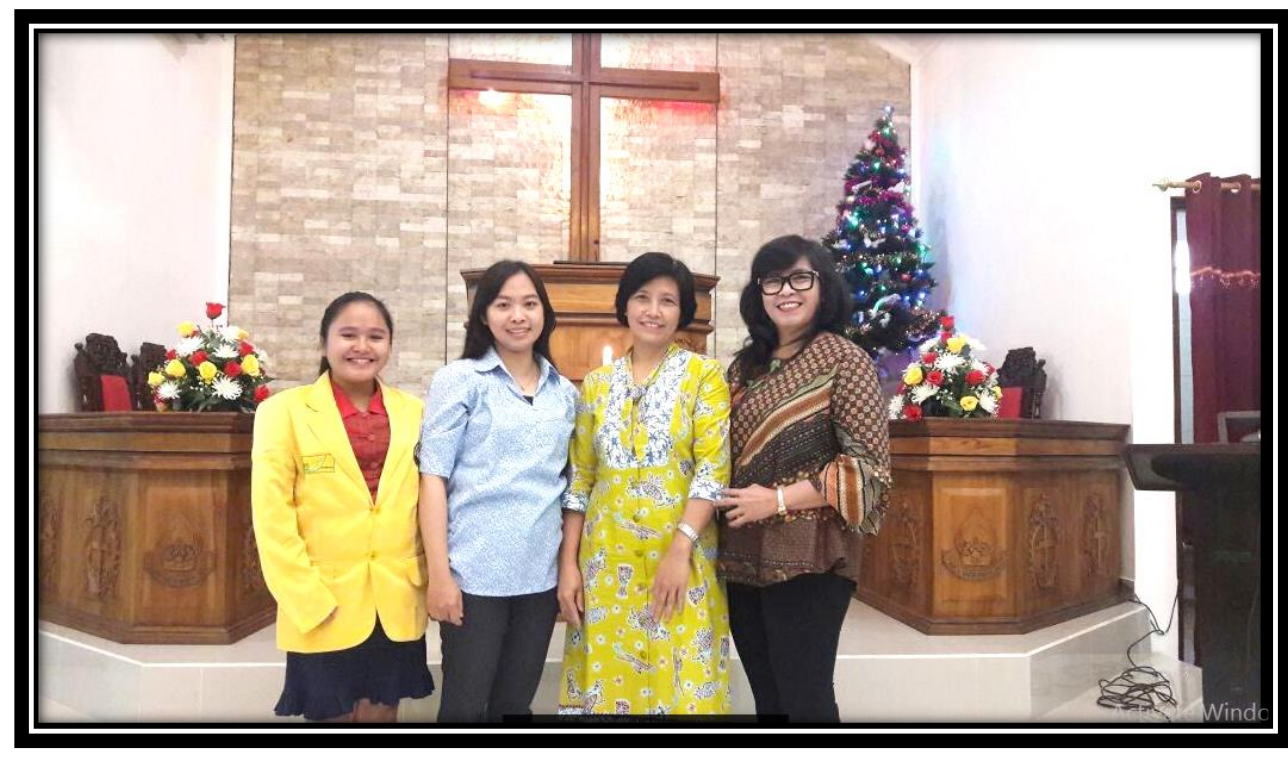

Gambar 4 Bersama Pemandu Nyanyian Jemaat GKJ Ngesrep

(Sumber: Dokumen Bella Monica Paula, 2018) 


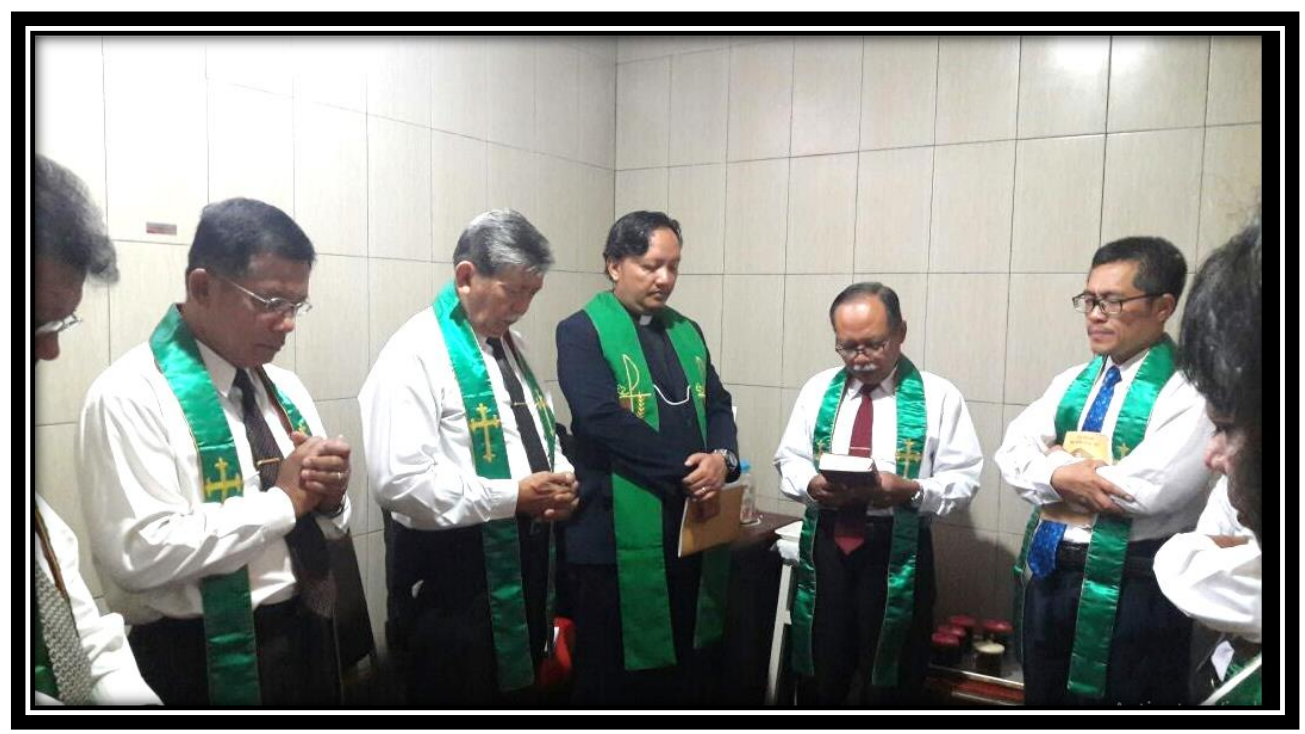

Gambar 5 Perkumpulan Pendeta dan Perangkat Sebelum Memulai Peribadatan di GKJ Ngesrep

(Sumber: Dokumen Bella Monica Paula, 2017)

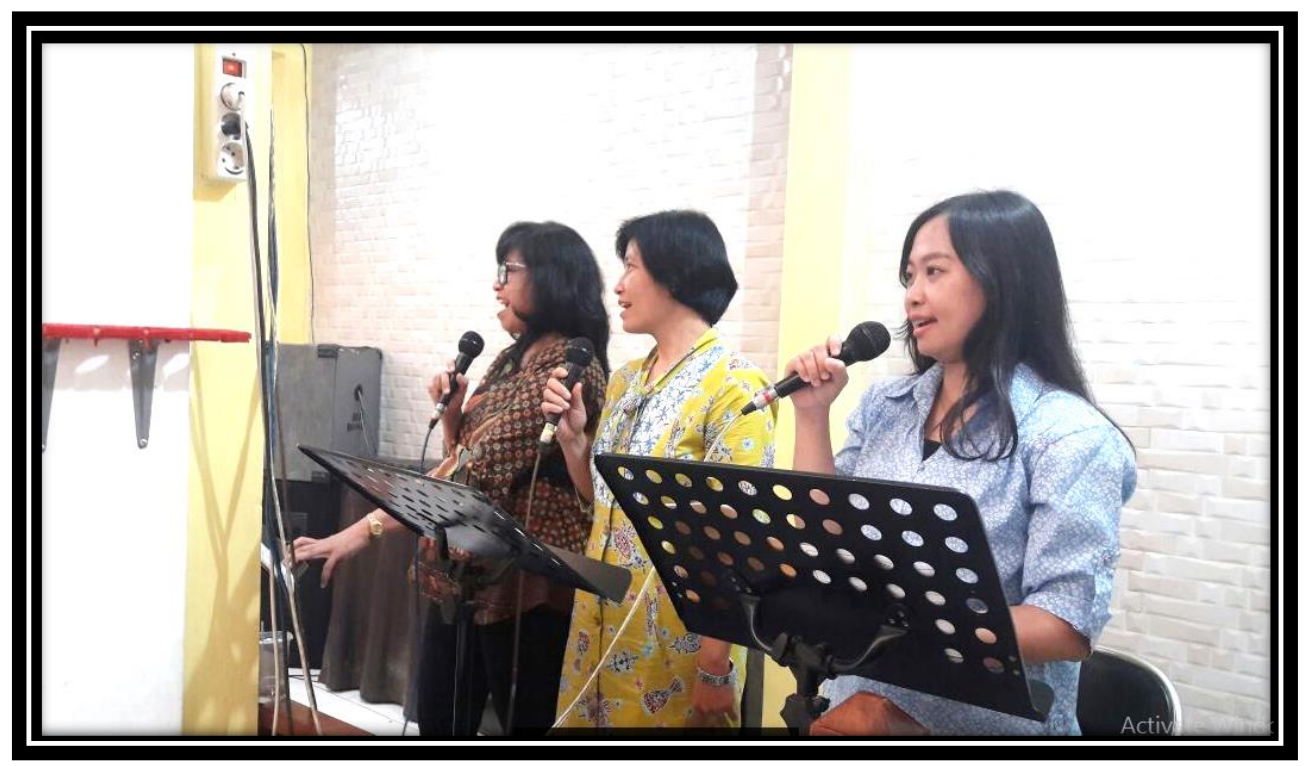

Gambar 6 Pemandu Nyanyian Jemaat GKJ Ngesrep Saat Bertugas dalam Peribadatan

(Sumber: Dokumen Bella Monica Paula, 2018) 


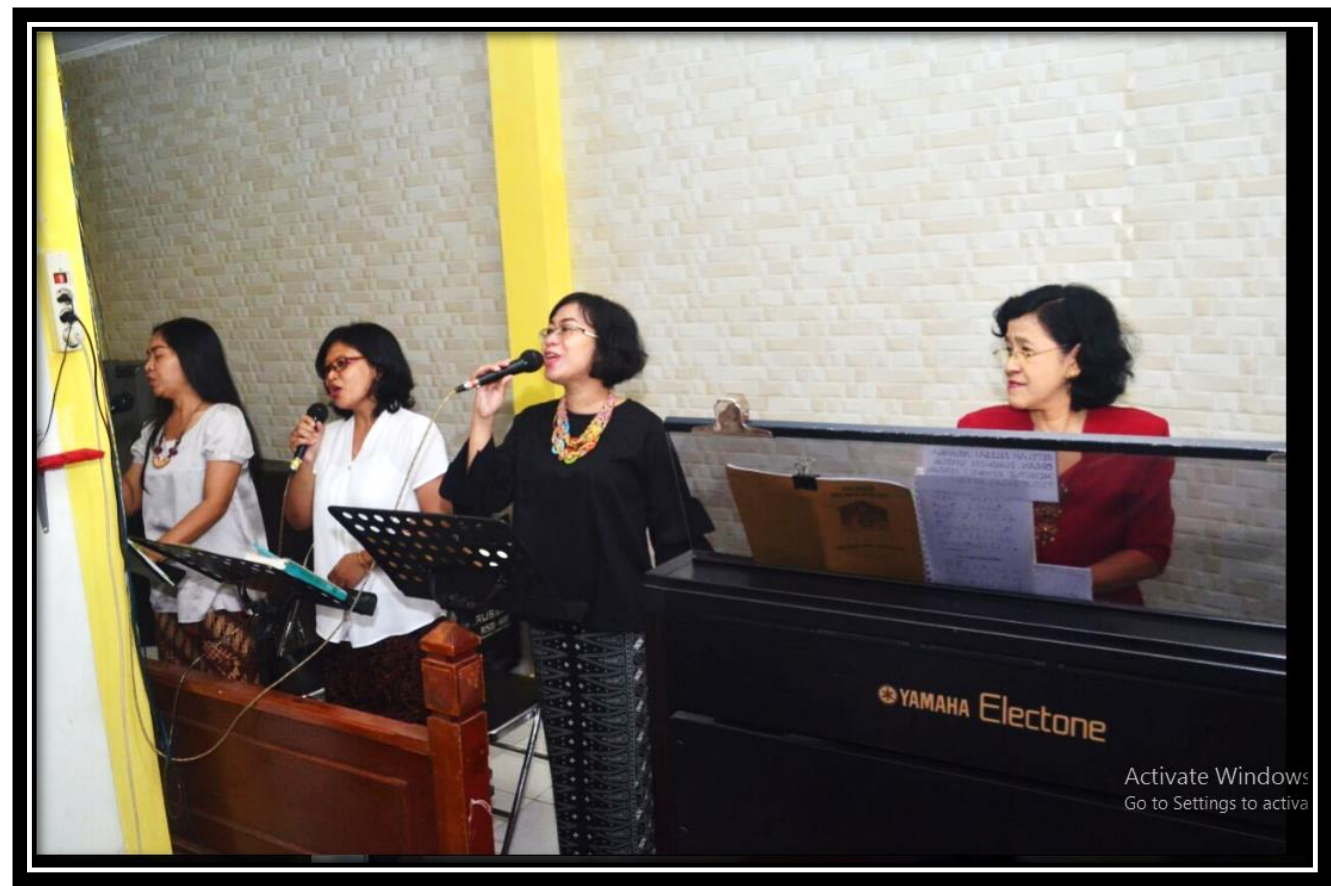

Gambar 7 Pemandu Nyanyian Jemaat Saat Bertugas dalam Peribadatan (Sumber: Dokumen Bella Monica Paula, 2017)

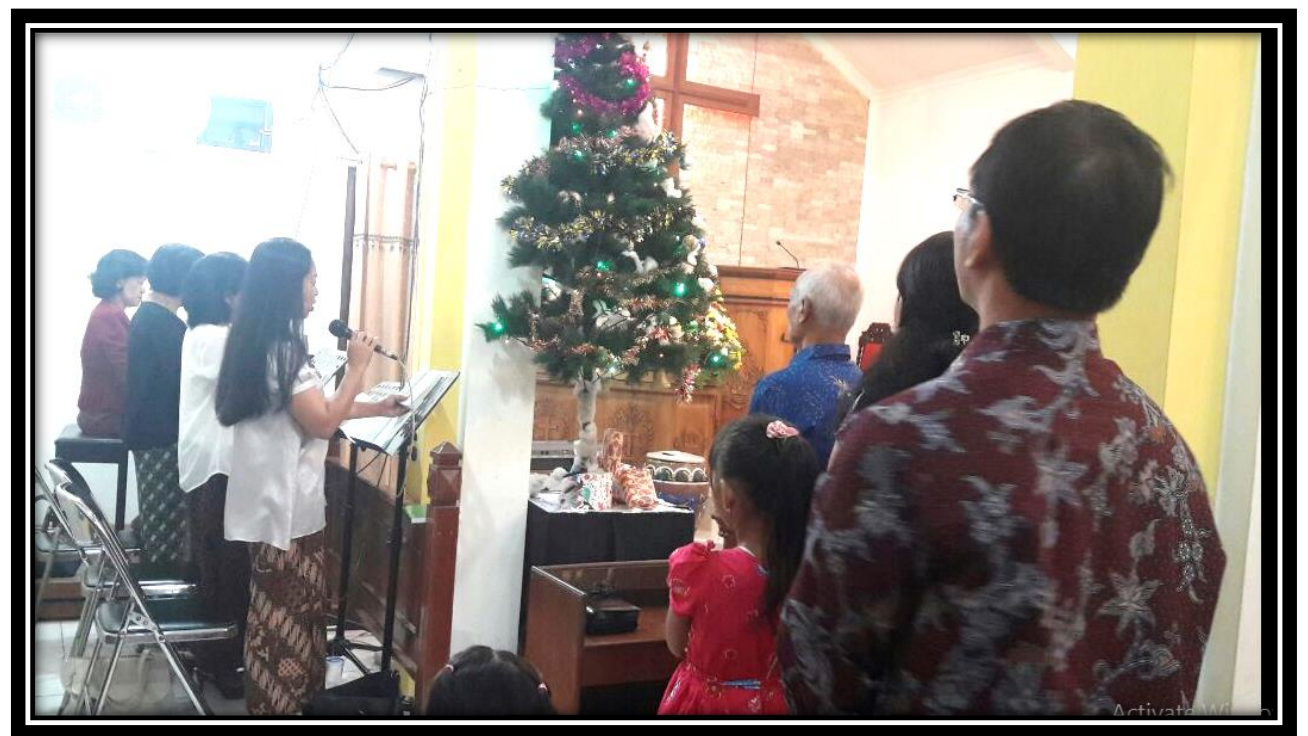

Gambar 8 Pemandu Nyanyian Jemaat Saat Bertugas dalam Peribadatan di GKJ Ngesrep

(Sumber: Dokumen Bella Monica Paula, 2017) 


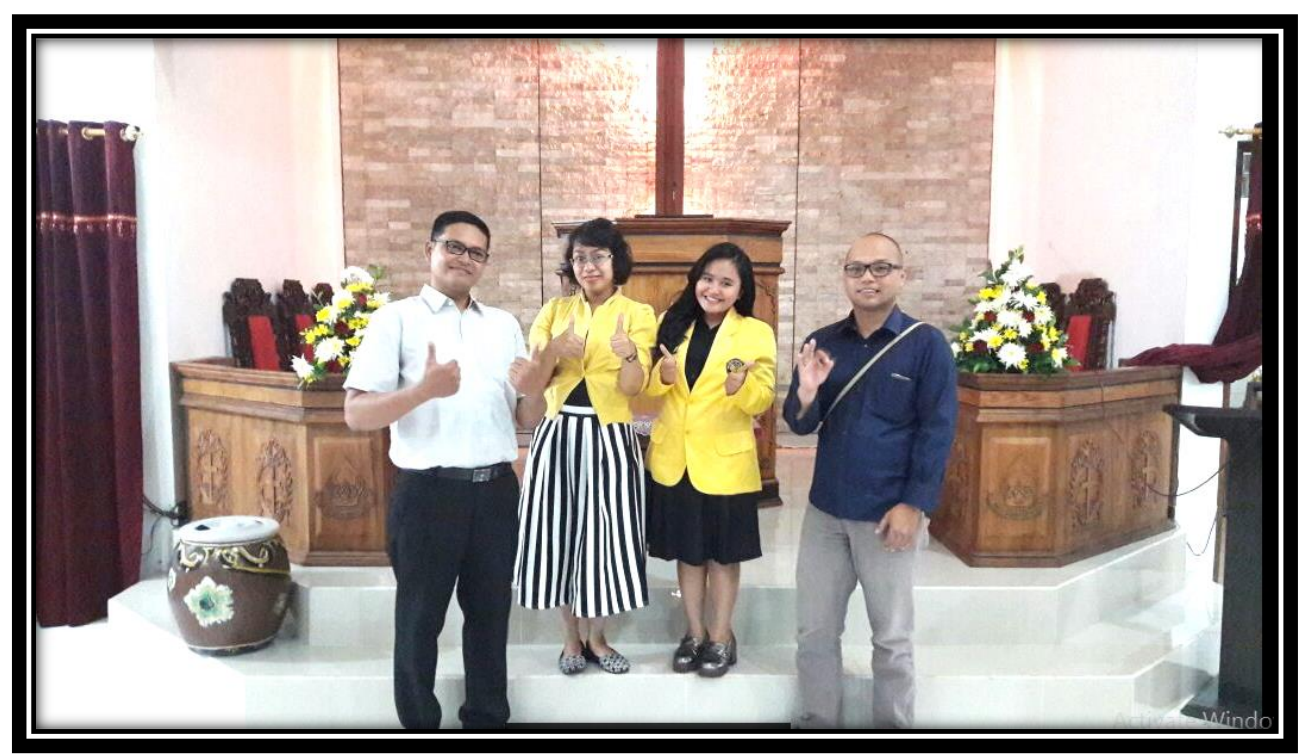

Gambar 9 Bersama Anggota Pemandu Nyanyian Jemaat di GKJ Ngesrep (Sumber: Dokumen Bella Monica Paula, 2018)

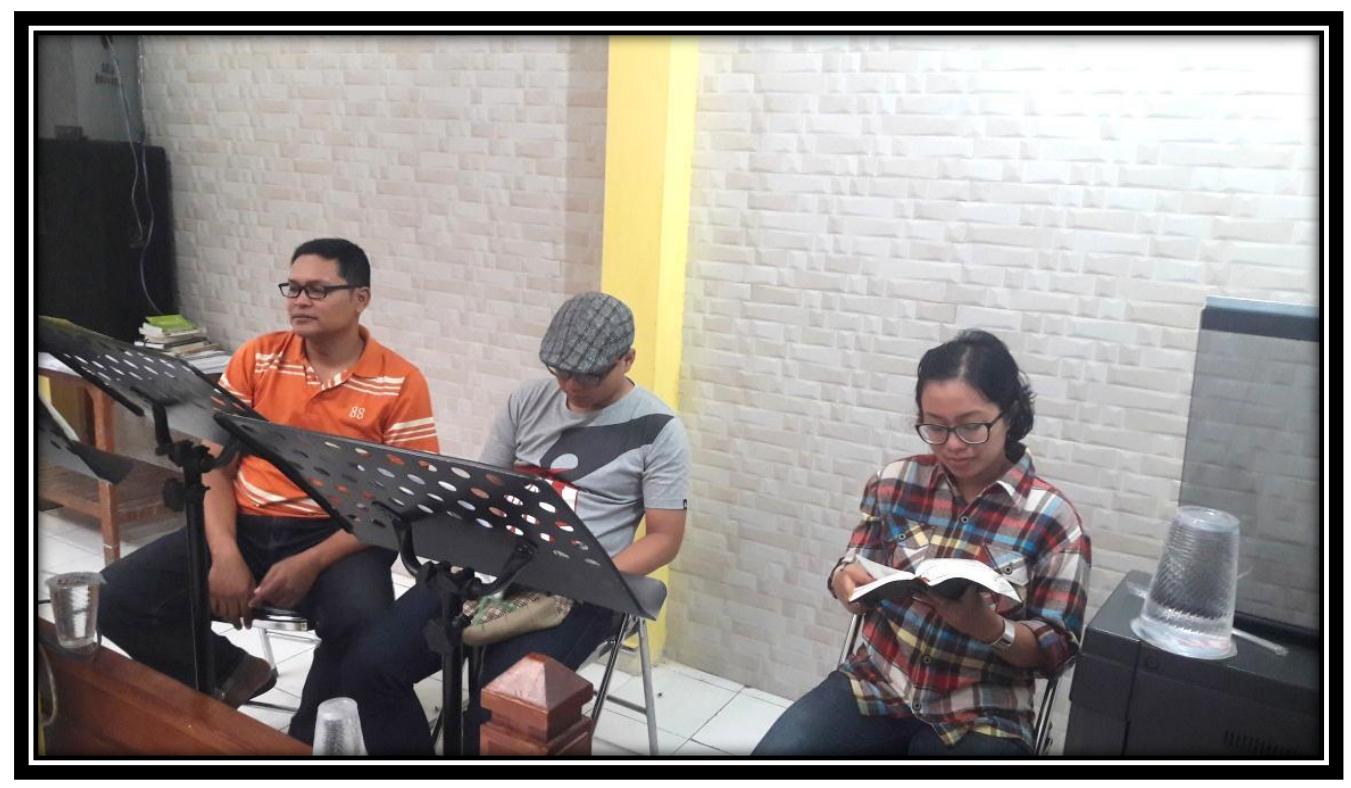

Gambar 10 Proses Latihan Pemandu Nyanyian Jemaat GKJ Ngesrep (Sumber: Dokumen Bella Monica Paula, 2018) 


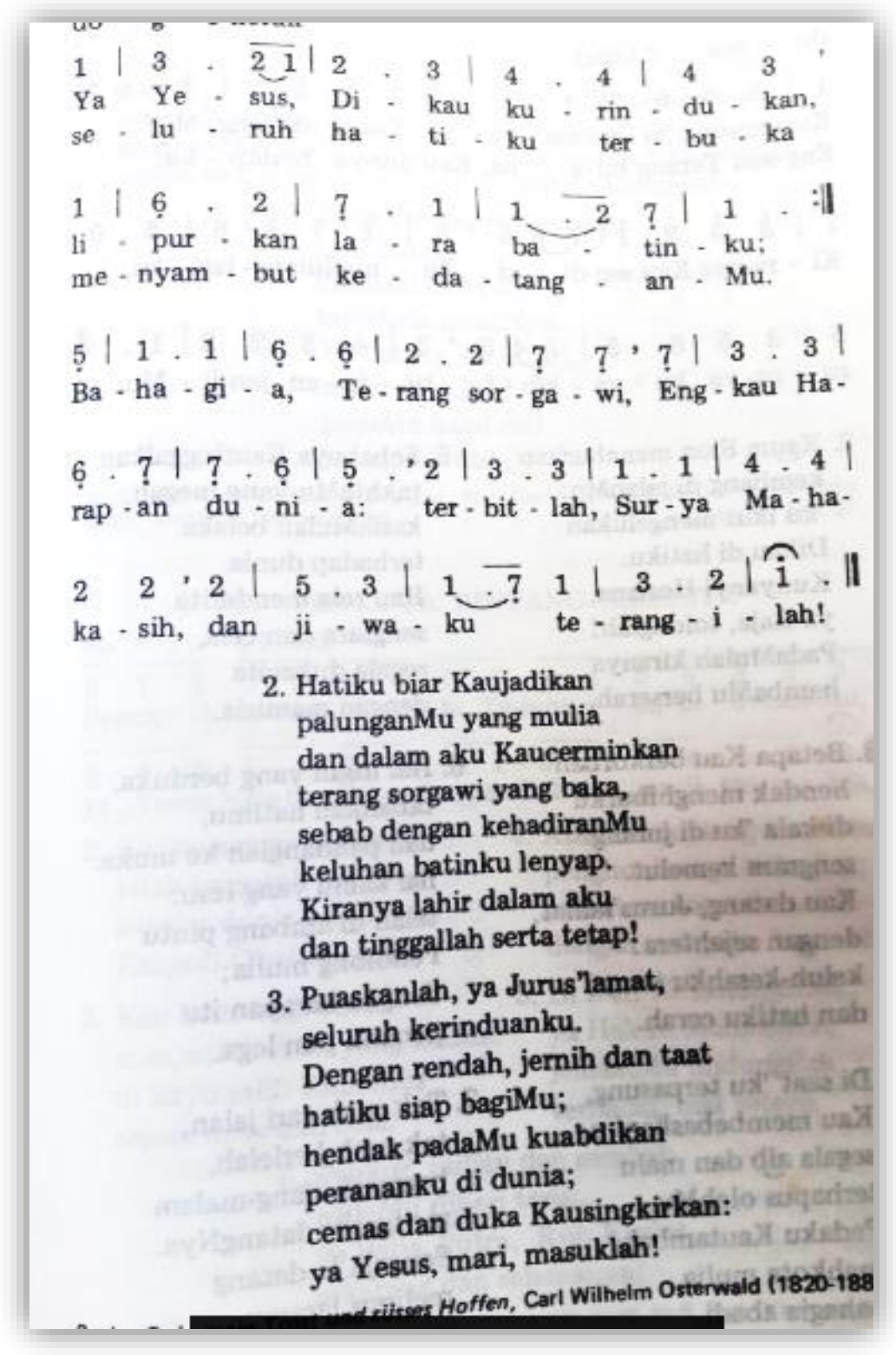

Gambar 11 Lirik dan Notasi Lagu di GKJ Ngesrep

(Sumber: Kidung Jemaat, 2005; 84) 


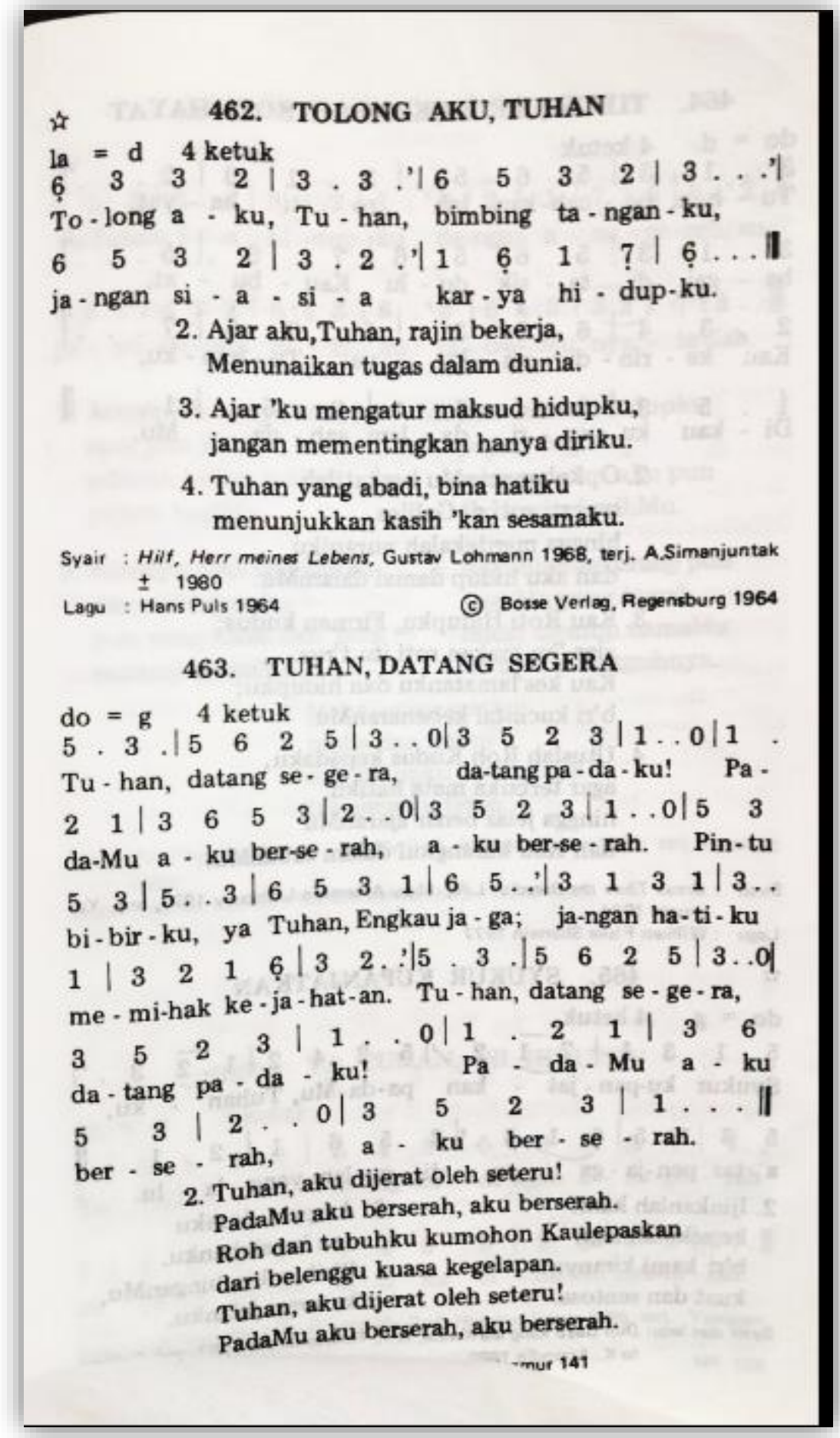

Gambar 12 Contoh Lagu dalam Peribadatan di GKJ Ngesrep (Sumber: Kidung Jemaat, 2005; 462) 


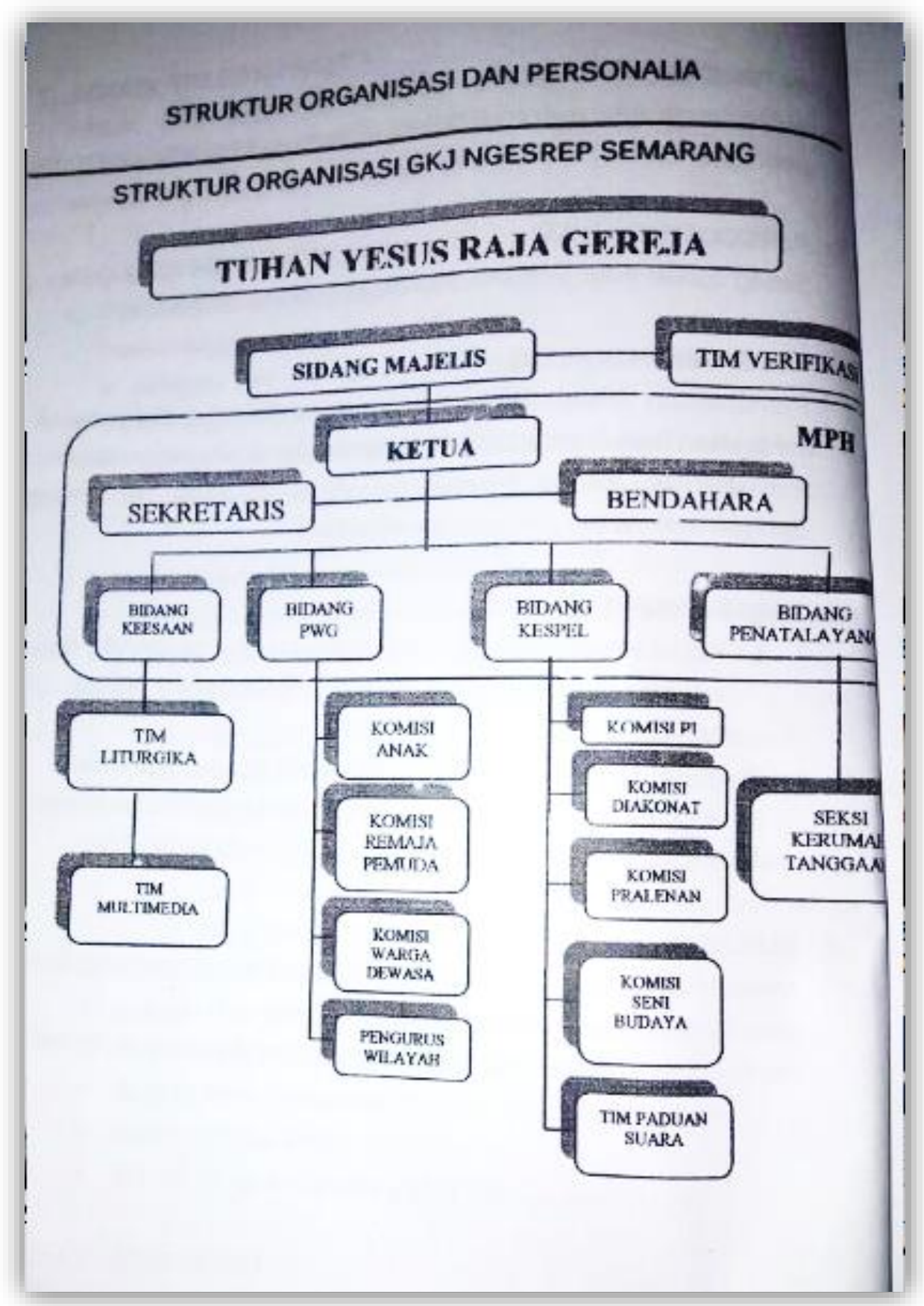

Gambar 13 Struktur Organisasi di GKJ Ngesrep

(Sumber: Stefanus Sugiman, 2017; 10) 


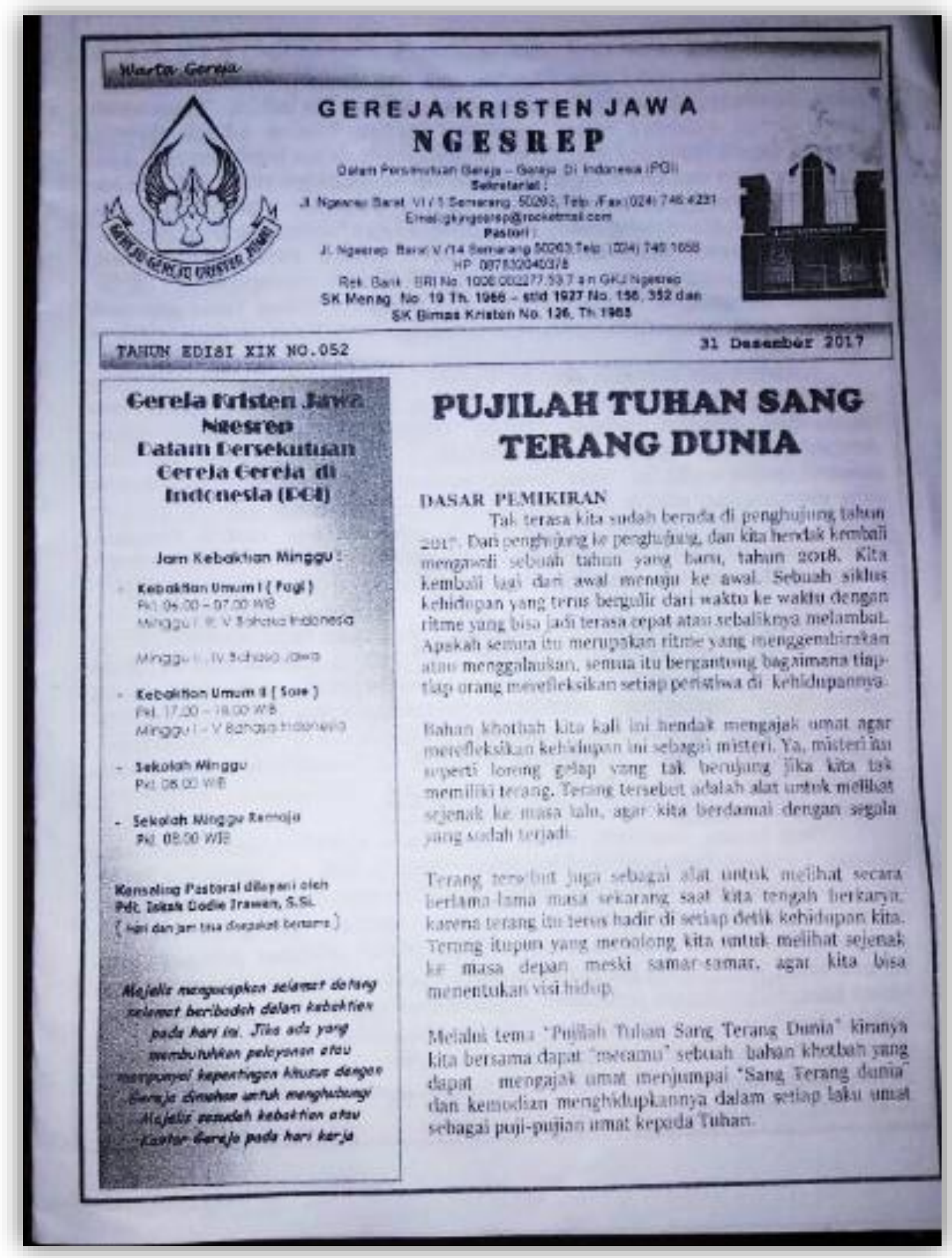

Gambar 14 Warta Gereja (Sumber: Warta Gereja Mingguan, 2017) 
Tabel 1

DAFTAR WARGA JEMAAT GEREJA KRISTEN JAWA NGESREP

\begin{tabular}{|c|c|c|c|c|}
\hline NO. & NIG. & NAMA & $\mathbf{L} / \mathbf{P}$ & ALAMAT \\
\hline 1 & 498 & Agoeng Noegroho & $\mathrm{L}$ & J1. Payung Asri Barat VIII/ 76 Banyumanik \\
\hline 2 & 499 & Ida Maryani Indri H. & $\mathrm{P}$ & J1. Payung Asri Barat VIII/ 76 Banyumanik \\
\hline 3 & 79 & Andreas Ngatiman & $\mathrm{L}$ & J1. Sendang Elo No. 9 Banyumanik \\
\hline 4 & 164 & $\begin{array}{l}\text { Kristien Dwi Puji } \\
\text { Rahayu }\end{array}$ & $\mathrm{P}$ & Jl. Sendang Elo No. 9 Banyumanik \\
\hline 5 & 261 & Stefanus Tri Nurcahyo & $\mathrm{L}$ & Jl. Sendang Elo No. 9 Banyumanik \\
\hline 6 & 467 & Binuka Adji Sedjati & $\mathrm{L}$ & $\begin{array}{l}\text { Perumahan Gedawang Permai Blok J / } 9 \\
\text { Banyumanik }\end{array}$ \\
\hline 7 & 468 & Asrini Poncowati & $\mathrm{P}$ & $\begin{array}{l}\text { Perumahan Gedawang Permai Blok J / } 9 \\
\text { Banyumanik }\end{array}$ \\
\hline 8 & 70 & Bambang Setiawan & $\mathrm{L}$ & Jl. Meranti Barat VI/226 Banyumanik \\
\hline 9 & 40 & E. Sri Sulistyantini & $\mathrm{P}$ & Jl. Meranti Barat VI/226 Banyumanik \\
\hline 10 & 189 & $\begin{array}{l}\text { Royce Wijaya Setya } \\
\text { Putra }\end{array}$ & $\mathrm{L}$ & Jl. Meranti Barat VI/226 Banyumanik \\
\hline 11 & & Monica Woro Ariarsi & $\mathrm{P}$ & J1. Meranti Barat VI/226 Banyumanik \\
\hline 12 & & $\begin{array}{l}\text { Chrismana Bagus } \\
\text { Priyatno }\end{array}$ & $\mathrm{L}$ & J1. Meranti Barat VI/226 Banyumanik \\
\hline 13 & 242 & Intan Permasari S. & $\mathrm{P}$ & J1. Meranti Barat VI/226 Banyumanik \\
\hline 14 & 336 & Djasno & $\mathrm{L}$ & $\begin{array}{l}\text { Asrama Kesdam IV Diponegoro - 51 Karang } \\
\text { Asem Semarang }\end{array}$ \\
\hline 15 & 227 & Supriyani & $\mathrm{P}$ & $\begin{array}{l}\text { Asrama Kesdam IV Diponegoro - 51 Karang } \\
\text { Asem Semarang }\end{array}$ \\
\hline 16 & 338 & Edi Suwarso & $\mathrm{L}$ & Jl. Gaharu Barat Dalam IV / 193 Banyumanik \\
\hline 17 & 339 & Kusbandiyah & $\mathrm{P}$ & Jl. Gaharu Barat Dalam IV / 193 Banyumanik \\
\hline 18 & 558 & Harvey Febrianta & $\mathrm{L}$ & J1. Gaharu Barat Dalam IV / 193 Banyumanik \\
\hline 19 & 216 & Warikem Lasijo Soelar & $\mathrm{P}$ & J1. Rumpun Diponegoro I / 94 Banyumanik \\
\hline 20 & 226 & Sri Waryanti & $\mathrm{P}$ & J1. Rumpun Diponegoro I / 94 Banyumanik \\
\hline 21 & 229 & Joko Saptono & $\mathrm{L}$ & Jl. Rumpun Diponegoro I / 94 Banyumanik \\
\hline 22 & 225 & Widi Tri Supadmi & $\mathrm{P}$ & J1. Rumpun Diponegoro I / 94 Banyumanik \\
\hline 23 & 489 & Dwi Suryatmi & $\mathrm{P}$ & Perum Delta Leyangan Ungaran \\
\hline 24 & 465 & Christine Dessy Barita & $\mathrm{P}$ & Perum Delta Leyangan Ungaran \\
\hline 25 & 488 & Bitania Devi Barita & $\mathrm{P}$ & Perum Delta Leyangan Ungaran \\
\hline 26 & & Lukas Kristianto & $\mathrm{L}$ & Perum Delta Leyangan Ungaran \\
\hline 27 & 334 & Asyera Dewi Barita & $\mathrm{P}$ & Perum Delta Leyangan Ungaran \\
\hline 28 & 671 & Ngatono & $\mathrm{L}$ & $\begin{array}{l}\text { Puri Gedawang Indah Blok E - } 11 \\
\text { Banyumanik }\end{array}$ \\
\hline 29 & 672 & Markamah & $\mathrm{P}$ & $\begin{array}{l}\text { Puri Gedawang Indah Blok E - } 11 \\
\text { Banyumanik }\end{array}$ \\
\hline 30 & 465 & Dony Setyawan & $\mathrm{L}$ & $\begin{array}{l}\text { Puri Gedawang Indah Blok E - } 11 \\
\text { Banyumanik }\end{array}$ \\
\hline 31 & 492 & Budiyanto & $\mathrm{L}$ & J1. Asri III / 17 Puri Asri Perdana Banyumanik \\
\hline 32 & 493 & Ridiawati Istiqomah & $\mathrm{P}$ & $\begin{array}{l}\text { Puri Gedawang Indah Blok E - } 11 \\
\text { Banyumanik }\end{array}$ \\
\hline 33 & 450 & Chandra Sangsoko & $\mathrm{L}$ & $\begin{array}{l}\text { Perum Aspol Gedawang } 2 \text { Blok C } 2 \\
\text { Banyumanik }\end{array}$ \\
\hline 34 & 596 & Dwi Kristiyani & $\mathrm{P}$ & Perum Aspol Gedawang 2 Blok C 2 \\
\hline
\end{tabular}




\begin{tabular}{|c|c|c|c|c|}
\hline & & & & Banyumanik \\
\hline 35 & 445 & R. Tri Widodo & $\mathrm{L}$ & $\begin{array}{l}\text { Griya Payung Indah G III RT01 RW } 15 \text { Pudak } \\
\text { Payung Banyumanik }\end{array}$ \\
\hline 36 & 458 & Yekti Jajanti & $\mathrm{P}$ & $\begin{array}{l}\text { Griya Payung Indah G III RT01 RW } 15 \text { Pudak } \\
\text { Payung Banyumanik }\end{array}$ \\
\hline 37 & 329 & Sukatmi Slamet Riyanto & $\mathrm{P}$ & J1. Temugiring Raya No. 6 A Banyumanik \\
\hline 38 & 332 & Didik Wahyu Utomo & $\mathrm{L}$ & J1. Temugiring Raya No. 6 A Banyumanik \\
\hline 39 & 663 & Eunike Suwarsi & $\mathrm{P}$ & J1. Temugiring Raya No. 6 A Banyumanik \\
\hline 40 & 69 & Sudirman & $\mathrm{L}$ & J1. Karangrejo Utara No. 25 Banyumanik \\
\hline 41 & 61 & Ester S. & $\mathrm{P}$ & J1. Karangrejo Utara No. 25 Banyumanik \\
\hline 42 & 244 & Vena R. Surya Putra & $\mathrm{L}$ & J1. Karangrejo Utara No. 25 Banyumanik \\
\hline 43 & 271 & Soekamto F. Karetji & $\mathrm{L}$ & J1. Diponegoro II / 17 Banyumanik \\
\hline 44 & 272 & Endang Swastuti & $\mathrm{P}$ & J1. Diponegoro II / 17 Banyumanik \\
\hline 45 & 76 & Rini Mulatsih & $\mathrm{P}$ & J1. Rumpun Diponegoro IX / 148 Banyumanik \\
\hline 46 & 466 & $\begin{array}{l}\text { Yudi Kristiawan } \\
\text { Nugroho }\end{array}$ & $\mathrm{L}$ & Asrama Kodam IV Wiratama Banyumanik \\
\hline 47 & 599 & Lukyriana S.P.R & $\mathrm{P}$ & Asrama Kodam IV Wiratama Banyumanik \\
\hline 48 & 443 & $\begin{array}{l}\text { Puguh Triandik } \\
\text { Guntoro }\end{array}$ & $\mathrm{L}$ & Asrama Brigif Blok R / 3 Banyumanik \\
\hline 49 & 326 & Veni Kristine Winati & $\mathrm{P}$ & Asrama Brigif Blok R / 3 Banyumanik \\
\hline 50 & 437 & $\begin{array}{l}\text { Yohanes Djawa Dwi } \\
\text { Sutoro }\end{array}$ & $\mathrm{L}$ & Asrama Brigif V H/ 6 Banyumanik \\
\hline 51 & 438 & Pudji Hastuti & $\mathrm{P}$ & Asrama Brigif V H/ 6 Banyumanik \\
\hline 52 & 165 & Yohanes Kastono & $\mathrm{L}$ & $\begin{array}{l}\text { Jl. Empu Sendok No. } 4 \text { Gedawang } \\
\text { Banyumanik }\end{array}$ \\
\hline 53 & 129 & Gumiarsih & $\mathrm{P}$ & $\begin{array}{l}\text { Jl. Empu Sendok No. } 4 \text { Gedawang } \\
\text { Banyumanik }\end{array}$ \\
\hline 54 & 243 & Lukas Iwan Setyawan & $\mathrm{L}$ & $\begin{array}{l}\text { Jl. Empu Sendok No. } 4 \text { Gedawang } \\
\text { Banyumanik }\end{array}$ \\
\hline 55 & 571 & Dita & $\mathrm{P}$ & $\begin{array}{l}\text { Jl. Empu Sendok No. } 4 \text { Gedawang } \\
\text { Banyumanik }\end{array}$ \\
\hline 56 & 559 & Luke Timor Ilingono & $\mathrm{L}$ & J1. Meranti Barat I / 349 Banyumanik \\
\hline 57 & 670 & Mirma Hapsari & $\mathrm{P}$ & Jl. Meranti Barat I / 349 Banyumanik \\
\hline 58 & 584 & $\begin{array}{l}\text { Ratna Yudari Tjahja } \\
\text { Prabowo }\end{array}$ & $\mathrm{P}$ & J1. Rumpun Diponegoro IX/147 Banyumanik \\
\hline 59 & 175 & Tri Iswanto & $\mathrm{L}$ & Perum Villa Krista Blok E / 7 Gedawang \\
\hline 60 & 144 & $\begin{array}{l}\text { Samuel Indah Puji } \\
\text { Lestari }\end{array}$ & $\mathrm{P}$ & Perum Villa Krista Blok E / 7 Gedawang \\
\hline 61 & 408 & Eunike Faralia Pradhita & & Perum Villa Krista Blok E / 7 Gedawang \\
\hline 62 & 640 & Nugroho & $\mathrm{L}$ & $\begin{array}{l}\text { Puri Gedawang Indah Blok E No. } 10 \\
\text { Banyumanik }\end{array}$ \\
\hline 63 & 641 & E. Sulistyowati & $\mathrm{P}$ & $\begin{array}{l}\text { Puri Gedawang Indah Blok E No. } 10 \\
\text { Banyumanik }\end{array}$ \\
\hline 64 & 601 & Sherly Christy Naftali & $\mathrm{P}$ & $\begin{array}{l}\text { Puri Gedawang Indah Blok E No. } 10 \\
\text { Banyumanik }\end{array}$ \\
\hline 65 & 637 & Dhaniel Kristiawan & $\mathrm{L}$ & $\begin{array}{l}\text { Puri Gedawang Indah Blok E No. } 10 \\
\text { Banyumanik }\end{array}$ \\
\hline 66 & 667 & Agung Kristiono & $\mathrm{L}$ & Perum Tembalang Pesona Asri K - 9 \\
\hline 67 & 668 & Ita Windriastuti & $\mathrm{P}$ & Perum Tembalang Pesona Asri K - 9 \\
\hline 68 & 416 & Frans Nico Koyongian & $\mathrm{L}$ & Jl. Sedang Elo No. 41 Banyumanik \\
\hline 69 & 608 & Haroem Poedjiarno & $\mathrm{L}$ & J1. Rasamala Barat VIII No. 264 Banyumanik \\
\hline
\end{tabular}




\begin{tabular}{|c|c|c|c|c|}
\hline 70 & 609 & Kunti Murtiningsih & $\mathrm{P}$ & J1. Rasamala Barat VIII No. 264 Banyumanik \\
\hline 71 & 675 & Willyam F. Sumani & $\mathrm{L}$ & Asrama Brigif V Banyumanik \\
\hline 72 & 676 & Ribut Miniasih & $\mathrm{P}$ & Asrama Brigif V Banyumanik \\
\hline 73 & 193 & Y. Sutrisni & $\mathrm{P}$ & J1. Kanfer Utara III No. 207 Banyumanik \\
\hline 74 & 372 & Friska F.ADP. & $\mathrm{P}$ & J1. Kanfer Utara III No. 207 Banyumanik \\
\hline 75 & 423 & $\begin{array}{l}\text { Kurniawan Eka } \\
\text { Wicaksana }\end{array}$ & $\mathrm{L}$ & J1. Kanfer Utara III No. 207 Banyumanik \\
\hline 76 & & $\begin{array}{l}\text { Tenggu Reje } \\
\text { Febriansyah }\end{array}$ & $\mathrm{L}$ & Mega Bukit mas Blok B no. 27 Gedawang \\
\hline 77 & 577 & Chintya Christy Dewi & $\mathrm{P}$ & Mega Bukit mas Blok B no. 27 Gedawang \\
\hline 78 & & Supanto & $\mathrm{L}$ & $\begin{array}{l}\text { Temu Giring RT.03 RW.05 No. } 10 \\
\text { Banyumanik }\end{array}$ \\
\hline 79 & & Endang Lestari & $\mathrm{P}$ & $\begin{array}{l}\text { Temu Giring RT.03 RW.05 No. } 10 \\
\text { Banyumanik }\end{array}$ \\
\hline 80 & 78 & Adi Purnomo Pilih & $\mathrm{L}$ & $\begin{array}{l}\text { J1. Potrosari Lapangan No. } 23 \text { A Srondol } \\
\text { Kulon }\end{array}$ \\
\hline 81 & 334 & Y. Sri Handayani & $\mathrm{P}$ & $\begin{array}{l}\text { Jl. Potrosari Lapangan No. } 23 \text { A Srondol } \\
\text { Kulon }\end{array}$ \\
\hline 82 & 345 & Betania Ika Rahayu & $\mathrm{P}$ & $\begin{array}{l}\text { J1. Potrosari Lapangan No. } 23 \text { A Srondol } \\
\text { Kulon }\end{array}$ \\
\hline 83 & 135 & Andreas Kartono & $\mathrm{L}$ & Cepersari Sarondol Kulon \\
\hline 84 & 348 & Suwarningsih & $\mathrm{P}$ & Cepersari Sarondol Kulon \\
\hline 85 & & Yanuwar Andreasnus S. & $\mathrm{L}$ & Cepersari Sarondol Kulon \\
\hline 86 & 409 & Desy Dwi Anggraheni & $\mathrm{P}$ & Cepersari Sarondol Kulon \\
\hline 87 & 535 & Arif Pudjiono & $\mathrm{L}$ & Cepersari Srondol Kulon \\
\hline 88 & 262 & Sulastri & $\mathrm{P}$ & Cepersari Sarondol Kulon \\
\hline 89 & 634 & Bagus Irawan & $\mathrm{L}$ & $\begin{array}{l}\text { Jl. Potrosari Lapangan No. } 25 \text { A Srondol } \\
\text { Kulon }\end{array}$ \\
\hline 90 & 239 & Agustin Kharolina Hadi & $\mathrm{P}$ & $\begin{array}{l}\text { J1. Potrosari Lapangan No. } 25 \text { A Srondol } \\
\text { Kulon }\end{array}$ \\
\hline 91 & 150 & Budi Aryanto & $\mathrm{L}$ & $\begin{array}{l}\text { Jl. Berdikari IV RT } 05 \text { / RW. VII Srondol } \\
\text { Kulon }\end{array}$ \\
\hline 92 & & Budi Rahayu & $\mathrm{P}$ & $\begin{array}{l}\text { Jl. Berdikari IV RT } 05 \text { / RW. VII Srondol } \\
\text { Kulon }\end{array}$ \\
\hline 93 & 44 & Dalimin & $\mathrm{L}$ & Cepersari Srondol Kulon \\
\hline 94 & 549 & Drajat Daru Prasetyo & $\mathrm{L}$ & Cepersari Srondol Kulon \\
\hline 95 & 550 & Yosari Windriasti & $\mathrm{P}$ & Cepersari Srondol Kulon \\
\hline 96 & 400 & Agus Sudiarto & $\mathrm{L}$ & J1. Potrosari I RT.06 RW. 02 Srondol Kulon \\
\hline 97 & 140 & Farida Erawati & $\mathrm{P}$ & J1. Potrosari I RT.06 RW. 02 Srondol Kulon \\
\hline 98 & 441 & $\begin{array}{l}\text { EPelayan } \\
\text { Firmanapraditus icha } \\
\text { Nanda Jati }\end{array}$ & $\mathrm{L}$ & J1. Potrosari I RT.06 RW. 02 Srondol Kulon \\
\hline 99 & 93 & $\begin{array}{l}\text { Filipus Sigit Endro } \\
\text { Cahyono }\end{array}$ & $\mathrm{L}$ & J1. Potrosari I RT.06 RW 02 Srondol Kulon \\
\hline 100 & 470 & Maryati & $\mathrm{P}$ & J1. Potrosari I RT.06 RW 02 Srondol Kulon \\
\hline 101 & 410 & $\begin{array}{l}\text { Antonius Chandra } \\
\text { Ginata }\end{array}$ & $\mathrm{L}$ & J1. Potrosari I RT.06 RW 02 Srondol Kulon \\
\hline 102 & & Emanuel Benu & $\mathrm{L}$ & Cepersari Srondol Kulon \\
\hline 103 & 491 & Ery Setyani & $\mathrm{P}$ & Cepersari Srondol Kulon \\
\hline 104 & 9 & Maryoto & $\mathrm{L}$ & Pucung Srondol Kulon \\
\hline 105 & 56 & Sumarmi & $\mathrm{P}$ & Pucung Srondol Kulon \\
\hline
\end{tabular}




\begin{tabular}{|c|c|c|c|c|}
\hline 106 & 635 & Atik Maryati & $\mathrm{P}$ & Pucung Srondol Kulon \\
\hline 107 & 3 & Ngoenandar & $\mathrm{L}$ & J1. Potrosari Tengah No. 18 Srondol Kulon \\
\hline 108 & 351 & Paulus Purnomo & $\mathrm{L}$ & $\begin{array}{l}\text { J1. Berdikari IV RT } 05 \text { / RW. VII Srondol } \\
\text { Kulon Semarang }\end{array}$ \\
\hline 109 & 113 & Amumpuni & $\mathrm{P}$ & $\begin{array}{l}\text { Jl. Berdikari IV RT } 05 \text { / RW. VII Srondol } \\
\text { Kulon Semarang }\end{array}$ \\
\hline 110 & 352 & Bella Monica Paula & $\mathrm{P}$ & $\begin{array}{l}\text { Jl. Berdikari IV RT } 05 \text { / RW. VII Srondol } \\
\text { Kulon Semarang }\end{array}$ \\
\hline 111 & 66 & Stefanus Sugiman & $\mathrm{L}$ & J1. Berdikari II No. 12 Srondol Kulon \\
\hline 112 & 77 & Purwati & $\mathrm{P}$ & J1. Berdikari II No. 12 Srondol Kulon \\
\hline 113 & 283 & Wulan Mahardika & $\mathrm{P}$ & J1. Berdikari II No. 12 Srondol Kulon \\
\hline 114 & 287 & Debora Kerentika & $\mathrm{P}$ & J1. Berdikari II No. 12 Srondol Kulon \\
\hline 115 & 506 & Sukarsan & $\mathrm{L}$ & J1. Kyai Mojo No. 45 Srondol Kulon \\
\hline 116 & 507 & Christina Kari Hartini & $\mathrm{P}$ & J1. Kyai Mojo No. 45 Srondol Kulon \\
\hline 117 & 508 & Pijar Kurniawan & $\mathrm{L}$ & J1. Kyai Mojo No. 45 Srondol Kulon \\
\hline 118 & 509 & Devinda Arsandi & $\mathrm{L}$ & J1. Kyai Mojo No. 45 Srondol Kulon \\
\hline 119 & 194 & Timotius Trulino & $\mathrm{L}$ & J1. Potrosari I RT. 06 RW 02 Srondol Kulon \\
\hline 120 & 290 & Eliana Ngatini & $\mathrm{P}$ & J1. Potrosari I RT. 06 RW 02 Srondol Kulon \\
\hline 121 & 304 & Tituk Santoso & $\mathrm{L}$ & $\begin{array}{l}\text { Jl. Potrosari Lapangan No. } 11 \text { A Srondol } \\
\text { Kulon }\end{array}$ \\
\hline 122 & 235 & Trusinah & $\mathrm{P}$ & $\begin{array}{l}\text { J1. Potrosari Lapangan No. } 11 \text { A Srondol } \\
\text { Kulon }\end{array}$ \\
\hline 123 & 560 & Santo Purna Aditya & $\mathrm{L}$ & $\begin{array}{l}\text { J1. Potrosari Lapangan No. } 11 \text { A Srondol } \\
\text { Kulon }\end{array}$ \\
\hline 124 & 196 & Sumirah Wadiran & $\mathrm{P}$ & Cepersari Srondol Kulon \\
\hline 125 & 137 & Martha Parini & $\mathrm{P}$ & Cepersari Srondol Kulon \\
\hline 126 & 523 & Y. Suparto & $\mathrm{L}$ & Cepersari Srondol Kulon \\
\hline 127 & 665 & Y. Sunaman & $\mathrm{L}$ & J1. Potrosari I RT.06 RW 02 Srondol Kulon \\
\hline 128 & 666 & Yulia Sutarmi & $\mathrm{P}$ & J1. Potrosari I RT.06 RW 02 Srondol Kulon \\
\hline 129 & 136 & Yonathan Kasmudji & $\mathrm{L}$ & Cepersari Srondol Kulon \\
\hline 130 & 346 & Dwi Purwantiningsih & $\mathrm{P}$ & Cepersari Srondol Kulon \\
\hline 131 & 39 & EA. Supartiwen & $\mathrm{P}$ & J1. Potrosari Balai Desa No. 1 Srondol Kulon \\
\hline 132 & 597 & Retiyadi & $\mathrm{L}$ & $\begin{array}{l}\text { Dusun Pakintelan RT.03 RW } 1 \text { kel. Pakintelan } \\
\text { Gunung Pati }\end{array}$ \\
\hline 133 & 603 & Endang Sri Hariyani & $\mathrm{P}$ & $\begin{array}{l}\text { Dusun Pakintelan RT.03 RW } 1 \text { kel. Pakintelan } \\
\text { Gunung Pati }\end{array}$ \\
\hline 134 & 592 & Alde Wisnu Nugroho & $\mathrm{L}$ & $\begin{array}{l}\text { Dusun Pakintelan RT.03 RW } 1 \text { kel. Pakintelan } \\
\text { Gunung Pati }\end{array}$ \\
\hline 135 & 611 & Didik Imawan & $\mathrm{L}$ & $\begin{array}{l}\text { Jl. Mulawarman Selatan Perum Citra Pesona } \\
\text { Blok A No. } 5 \text { Kramas. }\end{array}$ \\
\hline 136 & 612 & Noviana Indriani & $\mathrm{P}$ & $\begin{array}{l}\text { Jl. Mulawarman Selatan Perum Citra Pesona } \\
\text { Blok A No. } 5 \text { Kramas. }\end{array}$ \\
\hline 137 & 613 & $\begin{array}{l}\text { Fabriziano Divian } \\
\text { Nathanael }\end{array}$ & $\mathrm{L}$ & $\begin{array}{l}\text { J1. Mulawarman Selatan Perum Citra Pesona } \\
\text { Blok A No. } 5 \text { Kramas. }\end{array}$ \\
\hline 138 & 121 & Y. Tri Ernawati & $\mathrm{P}$ & J1. Potrosari Balai Desa No. 1 Srondol Kulon \\
\hline 139 & 658 & Joko Marwanto & $\mathrm{L}$ & $\begin{array}{l}\text { Jl. Potrosari Tengah No. } 21 \text { RT.04 RW VII } \\
\text { Srondol Kulon }\end{array}$ \\
\hline 140 & 659 & Sri Setya Damayanti & $\mathrm{P}$ & $\begin{array}{l}\text { Jl. Potrosari Tengah No. } 21 \text { RT.04 RW VII } \\
\text { Srondol Kulon }\end{array}$ \\
\hline 141 & 662 & Kadir & $\mathrm{L}$ & J1. Potrosari lapangan No. 24 Srondol Kulon \\
\hline 142 & 663 & Sri Rahayu & $\mathrm{P}$ & J1. Potrosari lapangan No. 24 Srondol Kulon \\
\hline
\end{tabular}




\begin{tabular}{|c|c|c|c|c|}
\hline 143 & 170 & Gera Aziz Kosasih & $\mathrm{L}$ & $\begin{array}{l}\text { Jl. Potrosari Lapangan No. } 23 \text { A Srondol } \\
\text { Kulon }\end{array}$ \\
\hline 144 & 684 & Novi Delina & $\mathrm{P}$ & $\begin{array}{l}\text { Jl. Potrosari Lapangan No. } 23 \text { A Srondol } \\
\text { Kulon }\end{array}$ \\
\hline 145 & 578 & Thomas Nugrahanto & $\mathrm{L}$ & $\begin{array}{l}\text { Jl. Berdikari VI RT.06 RW. VIII Srondol } \\
\text { Kulon }\end{array}$ \\
\hline 146 & 163 & Naomi Dwi Hapsari & $\mathrm{P}$ & $\begin{array}{l}\text { J1. Berdikari VI RT.06 RW. VIII Srondol } \\
\text { Kulon }\end{array}$ \\
\hline 147 & 266 & Bian Arianto & $\mathrm{L}$ & Jl. Berdikari Srondol Kulon \\
\hline 148 & 689 & Siti Muntafiah & $\mathrm{P}$ & J1. Berdikari Srondol Kulon \\
\hline 149 & 353 & Agus Nugroho & $\mathrm{L}$ & Jl. Ngesrep Barat VI/ 24 \\
\hline 150 & 354 & Rohyati Santoen & $\mathrm{P}$ & J1. Ngesrep Barat VI/ 24 \\
\hline 151 & 357 & Yulinar Friamsari & $\mathrm{P}$ & Jl. Ngesrep Barat VI/ 24 \\
\hline 152 & 426 & Agus Supriyanto & $\mathrm{L}$ & Jl. Bukit Seruni 18 Griya Bukit Mas \\
\hline 153 & 427 & Indriastuti W & $\mathrm{P}$ & J1. Bukit Seruni 18 Griya Bukit Mas \\
\hline 154 & 428 & Adrita Bima Adi & $\mathrm{L}$ & J1. Bukit Seruni 18 Griya Bukit Mas \\
\hline 155 & 429 & Adrita Nima Sari & $\mathrm{P}$ & J1. Bukit Seruni 18 Griya Bukit Mas \\
\hline 156 & & E. Arum Wahyuni & $\mathrm{P}$ & Jl. Gondang Barat VI/ 12 \\
\hline 157 & 421 & Hindiarno & $\mathrm{L}$ & Jl. Bukit Agung Blok L - 11 \\
\hline 158 & 422 & Ririt Asri Putri & $\mathrm{P}$ & Jl. Bukit Agung Blok L - 11 \\
\hline 159 & 424 & Dwi Krisnanto Aji & $\mathrm{L}$ & Jl. Bukit Agung Blok L -11 \\
\hline 160 & 425 & Satriya Triadhi Wibawa & $\mathrm{L}$ & Jl. Bukit Agung Blok L - 11 \\
\hline 161 & 59 & Hadi Sularmo & $\mathrm{L}$ & Jl. Ngesrep Timur I RT.01 RW 01 No 21 C \\
\hline 162 & 60 & Kristiana Hawai & $\mathrm{P}$ & J1. Ngesrep Timur I RT.01 RW 01 No 21 C \\
\hline 163 & 574 & Pudjianto MP. & $\mathrm{L}$ & Jl. Ngesrep Timur I RT.01 RW 01 No $21 \mathrm{C}$ \\
\hline 164 & 166 & Nurhayati & $\mathrm{P}$ & Jl. Ngesrep Timur I RT.01 RW 01 No $21 \mathrm{C}$ \\
\hline 165 & 359 & Hana Suyanti & $\mathrm{P}$ & Jl. Ngesrep Barat II RT.03 RW.06 \\
\hline 166 & 362 & Tri Pamungkas & $\mathrm{L}$ & J1. Ngesrep Barat II RT.03 RW.06 \\
\hline 167 & 444 & Iskak Dodie Irawan & $\mathrm{L}$ & J1. Ngesrep Barat V No. 14 \\
\hline 168 & 674 & Maria Denok Bekti A. & $\mathrm{P}$ & J1. Ngesrep Barat V No. 14 \\
\hline 169 & 398 & Istiarso & $\mathrm{L}$ & Jl. Ngesrep Timur IV NO. 2 \\
\hline 170 & 27 & Ester Rin SW. & $\mathrm{L}$ & Jl. Ngesrep Timur IV No. 10 \\
\hline 171 & 25 & Kardiman & $\mathrm{L}$ & J1. Ngesrep Barat I No. 47 \\
\hline 172 & 34 & Kaminah Supiyanto & $\mathrm{P}$ & J1. Ngesrep Barat II RT.03 RW.06 \\
\hline 173 & 677 & Mateus Sunnar & $\mathrm{L}$ & J1. Ngesrep Barat VI No. 42 Wisma Bum \\
\hline 174 & 678 & Humi Sundari Iswari & $\mathrm{P}$ & J1. Ngesrep Barat VI No. 42 Wisma Bum \\
\hline 175 & 310 & Mudjito & $\mathrm{L}$ & J1. Ngesrep Barat VI No. 26 Perum PLN \\
\hline 176 & 311 & Etty Budiastuti S. & $\mathrm{P}$ & Jl. Ngesrep Barat VI No. 26 Perum PLN \\
\hline 177 & 314 & Sabbat Nugroho Asji & $\mathrm{L}$ & J1. Ngesrep Barat VI No. 26 Perum PLN \\
\hline 178 & 713 & $\begin{array}{l}\text { Rela Saphira } \\
\text { Fadyamarta }\end{array}$ & $\mathrm{P}$ & J1. Ngesrep Barat VI No. 26 Perum PLN \\
\hline 179 & 315 & Fajar Jias Nugroho & $\mathrm{L}$ & J1. Ngesrep Barat VI No. 26 Perum PLN \\
\hline 180 & 205 & Minuk Sardiyatni Suki & $\mathrm{P}$ & Jl. Ngesrep Barat VI No. 19 Perum PLN \\
\hline 181 & 404 & Baskoro Arief Widodo & $\mathrm{L}$ & J1. Ngesrep Barat VI No. 19 Perum PLN \\
\hline 182 & 374 & Dhanik Ramadiana & $\mathrm{P}$ & J1. Ngesrep Barat VI No. 19 Perum PLN \\
\hline 183 & 231 & Munasih & $\mathrm{P}$ & J1. Ngesrep Barat IV No. 35 A \\
\hline 184 & 681 & Nina Woelan S. & $\mathrm{P}$ & J1. Durian Utara II Dalam Srondol Wetan \\
\hline 185 & 482 & Julio Bagas Hernianto & $\mathrm{L}$ & J1. Durian Utara II Dalam Srondol Wetan \\
\hline 186 & 82 & Petrus Paranto & $\mathrm{L}$ & Jl. Ngesrep Barat II No. 3 \\
\hline
\end{tabular}




\begin{tabular}{|c|c|c|c|c|}
\hline 187 & 83 & Sumiyati & $\mathrm{P}$ & J1. Ngesrep Barat II No. 3 \\
\hline 188 & & Endah Arvianti & $\mathrm{P}$ & Jl. Ngesrep Barat II No. 3 \\
\hline 189 & 391 & $\begin{array}{l}\text { R.M. Bambang } \\
\text { Sumbardiyanto }\end{array}$ & $\mathrm{L}$ & J1. Ngesrep Barat VI No. 39 A \\
\hline 190 & 90 & Supiyah & $\mathrm{P}$ & Jl. Ngesrep Barat VI No. 39 A \\
\hline 191 & 392 & Kuncoro Sekar jati & $\mathrm{L}$ & J1. Ngesrep Barat VI No. 39 A \\
\hline 192 & 393 & $\begin{array}{l}\text { Hanjoyo Prasetyo } \\
\text { Utomo }\end{array}$ & $\mathrm{L}$ & J1. Ngesrep Barat VI No. 39 A \\
\hline 193 & 52 & Theresia Suparmi & $\mathrm{P}$ & Jl. Ngesrep Barat VI No. 39 A \\
\hline 194 & & $\begin{array}{l}\text { Yohana Ajeng } \\
\text { Handayani }\end{array}$ & $\mathrm{P}$ & Jl. Ngesrep Barat VI No. 39 A \\
\hline 195 & 98 & Rusmiyati & $\mathrm{P}$ & Jl. Ngesrep Barat II No. 3 \\
\hline 196 & 636 & Tus Setyo Bantolo & $\mathrm{L}$ & Jl. Ngesrep Barat II No. 3 \\
\hline 197 & 363 & Sutri & $\mathrm{L}$ & Jl. Ngesrep Barat dalam I \\
\hline 198 & & Sumilah Sumarno & $\mathrm{P}$ & Jl. Tanjung Sari RT.01 RW.02 Srondol Wetan \\
\hline 199 & & Firman Triyanto & $\mathrm{L}$ & Jl. Tanjung Sari RT.01 RW.02 Srondol Wetan \\
\hline 200 & 616 & Bero Ariani Bibit & $\mathrm{P}$ & Jl. Tanjung Sari RT.01 RW.02 Srondol Wetan \\
\hline 201 & 57 & Slamet Diyanto & $\mathrm{L}$ & Jl. Ngesrep Barat VI No. 45 Wisma Bum \\
\hline 202 & 10 & Sriyati & $\mathrm{P}$ & Jl. Ngesrep Barat VI No. 45 Wisma Bum \\
\hline 203 & 214 & Sadrach Ngustadi & $\mathrm{L}$ & Jl. Ngesrep Barat II No. 3 \\
\hline 204 & 679 & Martha Yuliati & $\mathrm{P}$ & Jl. Ngesrep Barat II No. 3 \\
\hline 205 & 693 & Betseba Serinda Liliani & $\mathrm{P}$ & J1. Ngesrep Barat II No. 3 \\
\hline 206 & 457 & Sudadi & $\mathrm{L}$ & $\begin{array}{l}\text { Perum. Bukit Emerald Jaya Blok C1 no } 15 \\
\text { Meteseh }\end{array}$ \\
\hline 207 & 158 & Ananingtyas Puji Untari & $\mathrm{P}$ & $\begin{array}{l}\text { Perum. Bukit Emerald Jaya Blok C1 no } 15 \\
\text { Meteseh }\end{array}$ \\
\hline 208 & 462 & $\begin{array}{l}\text { Nathaniel Suryo } \\
\text { Anggoro Djati }\end{array}$ & $\mathrm{L}$ & $\begin{array}{l}\text { Perum. Bukit Emerald Jaya Blok C1 no } 15 \\
\text { Meteseh }\end{array}$ \\
\hline 209 & 19 & $\begin{array}{l}\text { Supi Supiyah Martin } \\
\text { Manuputty }\end{array}$ & $\mathrm{P}$ & J1. Ngesrep Timur I No. 24 \\
\hline 210 & 269 & $\begin{array}{l}\text { Hary Benjamin } \\
\text { Manuputty }\end{array}$ & $\mathrm{L}$ & Jl. Ngesrep Timur I No. 24 \\
\hline 211 & 572 & Surati Ari Krisetyowati & $\mathrm{P}$ & Jl. Ngesrep Timur I No. 24 \\
\hline 212 & 541 & Sri Widekso & $\mathrm{L}$ & Jl. Ngesrep Barat VI No. 31 Perum PLN \\
\hline 213 & 664 & Asrining Lir Amrih & $\mathrm{P}$ & Jl. Ngesrep Barat VI No. 31 Perum PLN \\
\hline 214 & 542 & Yuni Widyastuti & $\mathrm{P}$ & Jl. Ngesrep Barat VI No. 31 Perum PLN \\
\hline 215 & 543 & $\begin{array}{l}\text { Agus Widi Sukmo } \\
\text { Wibowo }\end{array}$ & $\mathrm{L}$ & Jl. Ngesrep Barat VI No. 31 Perum PLN \\
\hline 216 & 395 & Suhartono & $\mathrm{L}$ & Jl. Ngesrep Barat II No. 04 \\
\hline 217 & 120 & Maria Kristiningsih & $P$ & Jl. Ngesrep Barat II No. 04 \\
\hline 218 & 397 & Widi Krishartono & $\mathrm{L}$ & Jl. Ngesrep Barat II No. 04 \\
\hline 219 & 397 & Dian Putri Puspitasari & $\mathrm{P}$ & J1. Ngesrep Barat II No. 04 \\
\hline 220 & & Ngapiyah & $\mathrm{P}$ & Jl. Ngesrep Barat III No. 42 \\
\hline 221 & & Sri Endaryanti & $\mathrm{P}$ & Jl. Ngesrep Barat III No. 42 \\
\hline 222 & & Agus Raharjo & $\mathrm{L}$ & Jl. Ngesrep Barat III No. 42 \\
\hline 223 & & Joko Purwanto & $\mathrm{L}$ & J1. Ngesrep Barat III No. 42 \\
\hline 224 & & Tri Hartini & $\mathrm{P}$ & Jl. Ngesrep Barat III No. 42 \\
\hline 225 & 8 & Sulimin & $\mathrm{L}$ & Jl. Ngesrep Barat II No. 04 \\
\hline 226 & 233 & Sukamto & $\mathrm{L}$ & J1. Ngesrep Barat Dalam I No. 58 \\
\hline 227 & 540 & Evie Hestiningrum & $\mathrm{P}$ & Jl. Ngesrep Barat Dalam I No. 58 \\
\hline
\end{tabular}




\begin{tabular}{|c|c|c|c|c|}
\hline 228 & 295 & Sudarmi & $\mathrm{P}$ & J1. Ngesrep Barat VI \\
\hline 229 & 298 & Agung Wibowo & $\mathrm{L}$ & Jl. Ngesrep Barat VI \\
\hline 230 & 51 & Solikin & $\mathrm{L}$ & J1. Ngesrep Barat Dalam I No. 58 \\
\hline 231 & 378 & Thomas Pandiono & $\mathrm{L}$ & J1. Ngesrep Barat V No. 27 \\
\hline 232 & 381 & Afin Wahyu Nugroho & $\mathrm{L}$ & Jl. Ngesrep Barat V No. 27 \\
\hline 233 & 383 & Selvi Dian Nugraheni & $\mathrm{P}$ & Jl. Ngesrep Barat V No. 27 \\
\hline 234 & 418 & Untoro Nugroho & $\mathrm{L}$ & $\begin{array}{l}\text { Jl. Sipodang Dalam Rt. } 04 \text { RW. } 02 \\
\text { Tembalang. }\end{array}$ \\
\hline 235 & 419 & Ester Setyaningsih & $\mathrm{P}$ & $\begin{array}{l}\text { Jl. Sipodang Dalam Rt. } 04 \text { RW. } 02 \\
\text { Tembalang. }\end{array}$ \\
\hline 236 & 420 & Lidia Kristia Alfanti & $P$ & $\begin{array}{l}\text { Jl. Sipodang Dalam Rt. } 04 \text { RW. } 02 \\
\text { Tembalang. }\end{array}$ \\
\hline 237 & 385 & Wahyu Widayanto & $\mathrm{L}$ & J1. Ngesrep Timur III No. 21 Perum PLN \\
\hline 238 & 386 & Sri Sukarti & $\mathrm{P}$ & Jl. Ngesrep Timur III No. 21 Perum PLN \\
\hline 239 & 389 & $\begin{array}{l}\text { Martha Dian Tri } \\
\text { Wahyuni }\end{array}$ & $\mathrm{P}$ & Jl. Ngesrep Timur III No. 21 Perum PLN \\
\hline 240 & 390 & $\begin{array}{l}\text { Efrat Bambang Adi } \\
\text { Nugroho }\end{array}$ & $\mathrm{L}$ & Jl. Ngesrep Timur III No. 21 Perum PLN \\
\hline 241 & 707 & Yanuardi Wisnu Sejati & $\mathrm{L}$ & Jl. Ngesrep Timur III No. 21 Perum PLN \\
\hline 242 & & Y. Sulastri & $\mathrm{P}$ & Jl. Ngesrep Timur IV No. 4 B \\
\hline 243 & 557 & Atika Bing Arianti & $\mathrm{P}$ & Jl. Ngesrep Timur IV No. 4 B \\
\hline 244 & & Eko Haryanto & $\mathrm{L}$ & Jl. Ngesrep Timur IV No. 4 B \\
\hline 245 & 605 & Wisnu Widiatmoko & $\mathrm{L}$ & $\begin{array}{l}\text { Perum Tembalang Makmur Asdri Jl. Bulusan } \\
\text { I / A } 33\end{array}$ \\
\hline 246 & 606 & Dyah Indarti & $\mathrm{P}$ & $\begin{array}{l}\text { Perum Tembalang Makmur Asdri Jl. Bulusan } \\
\text { I / A } 33\end{array}$ \\
\hline 247 & 617 & Krisna Indriastanti & $\mathrm{P}$ & Griya Tembalang \\
\hline 248 & 627 & Mulatto & $\mathrm{L}$ & Jl. Ngesrep Barat Dalam V No. 17 \\
\hline 249 & 628 & Soegiarti & $\mathrm{P}$ & J1. Ngesrep Barat Dalam V No. 17 \\
\hline 250 & 624 & Cahyo Budi Santoso & $\mathrm{L}$ & Jl. Ngesrep Barat Dalam IV \\
\hline 251 & 625 & Siskawati Widiyanti & $\mathrm{P}$ & Jl. Ngesrep Barat Dalam IV \\
\hline 252 & 561 & $\begin{array}{l}\text { Sri Rayahu Hartono } \\
\text { Tendo }\end{array}$ & $\mathrm{P}$ & Jl. Ngesrep Barat VI No. 39 \\
\hline 253 & 275 & Surip & $\mathrm{P}$ & J1. Jatisari II/ 6 Tembalang \\
\hline 254 & 276 & Sri Estiningsih & $\mathrm{P}$ & Jl. Jatisari II/ 6 Tembalang \\
\hline 255 & 277 & Kristiningsih & $\mathrm{P}$ & Jl. Jatisari II/ 6 Tembalang \\
\hline 256 & 279 & Maryani Dewi & $\mathrm{P}$ & Jl. Jatisari II/ 6 Tembalang \\
\hline 257 & 309 & Kristianto & $\mathrm{L}$ & Jl. Jatisari II/ 6 Tembalang \\
\hline 258 & 280 & Aris Achiranto & $\mathrm{L}$ & J1. Jatisari II/ 6 Tembalang \\
\hline 259 & 481 & $\begin{array}{l}\text { Ruth Eni Haryanti } \\
\text { Sudirdjo }\end{array}$ & $\mathrm{P}$ & $\begin{array}{l}\text { Rumdin PU Pengairan Jl. Ngesrep Timur V } \\
\text { No. } 38\end{array}$ \\
\hline 260 & 673 & Talarima Rian Danis & $\mathrm{L}$ & J1. Ngesrep Barat VI No. 42 Perum PLN \\
\hline 261 & 598 & Purwati & $\mathrm{P}$ & Jl. Ngesrep Barat VI No. 42 Perum PLN \\
\hline 262 & 485 & Rudi Kurniawan & $\mathrm{L}$ & Jl. Ngesrep Timur III Rumdin PLN No. 12 \\
\hline 263 & 701 & Hermien Susilawati & $\mathrm{P}$ & Pondok Bukit Agung E-35 Ngesrep \\
\hline 264 & & Rio & $\mathrm{L}$ & Pondok Bukit Agung E-35 Ngesrep \\
\hline 265 & 683 & Harum Pudjiastuti & $\mathrm{P}$ & Ngesrep Barat VI No. 8 \\
\hline 266 & 680 & Suistini & $\mathrm{P}$ & Jl. Ngesrep Timur V Dalam I No. 31 C \\
\hline 267 & 586 & Susatyo Handoko & $\mathrm{L}$ & $\begin{array}{l}\text { Jl. Anggrek I / E } 336 \text { Perum Bukit } \\
\text { Diponegoro Tembalang }\end{array}$ \\
\hline
\end{tabular}




\begin{tabular}{|l|l|l|c|l|}
268 & 587 & Wahyu Jati Lestari & P & $\begin{array}{l}\text { Jl. Anggrek I / E 336 Perum Bukit } \\
\text { Diponegoro Tembalang }\end{array}$ \\
\hline 269 & 704 & Yosafat Wisnu & L & Jl. Ngesrep Barat VI No. 26 Perum PLN \\
\hline 270 & 312 & Fista Setyaning Astuti & P & Jl. Ngesrep Barat VI No. 26 Perum PLN \\
\hline 271 & 707 & Puji Dwiyatmi & P & Perum Villa tembalang Blok K / 7 \\
\hline 272 & 720 & Sumarni & P & Perum Villa tembalang Blok K / 7 \\
\hline 273 & 710 & $\begin{array}{l}\text { Dhaifur Rahman Akbar } \\
\text { Bagaskara }\end{array}$ & L & Perum Villa tembalang Blok K / 7 \\
\hline 274 & 261 & Wanto Hatmoko & L & Jl. Ngesrep Timur II \\
\hline 275 & 623 & Benedict Pastukalana & L & Jl. Ngesrep Timur II \\
\hline 276 & 706 & Dhomy Prakosa & L & Jl. Bukit Palem Kipas I, Blok J.3 / 10 Meteseh \\
\hline 277 & & Santi Yusniardi & P & Jl. Bukit Palem Kipas I, Blok J.3 / 10 Meteseh \\
\hline 278 & & Yunus Soenarto & L & Jl. Ngesrep Barat I \\
\hline 279 & & Mintosih & P & Jl. Ngesrep Barat I \\
\hline 280 & & Sri Hayati & P & Jl. Ngesrep Barat I \\
\hline 281 & & Sumarsono & L & Jl. Bukit Agung Blok O / 10 Ngesrep \\
\hline 282 & & Wulan Sumekar & P & Jl. Bukit Agung Blok O / 10 Ngesrep \\
\hline 283 & & Galuh Ajeng H. & P & Jl. Bukit Agung Blok O / 10 Ngesrep \\
\hline 284 & & Iman Kris Nugroho & P & Jl. Bukit Agung Blok O / 10 Ngesrep \\
\hline
\end{tabular}

Gambar 15 Daftar Warga Jemaat Gereja Kristen Jawa Ngesrep

(Sumber: Dokumen Bella Monica Paula, 2017)

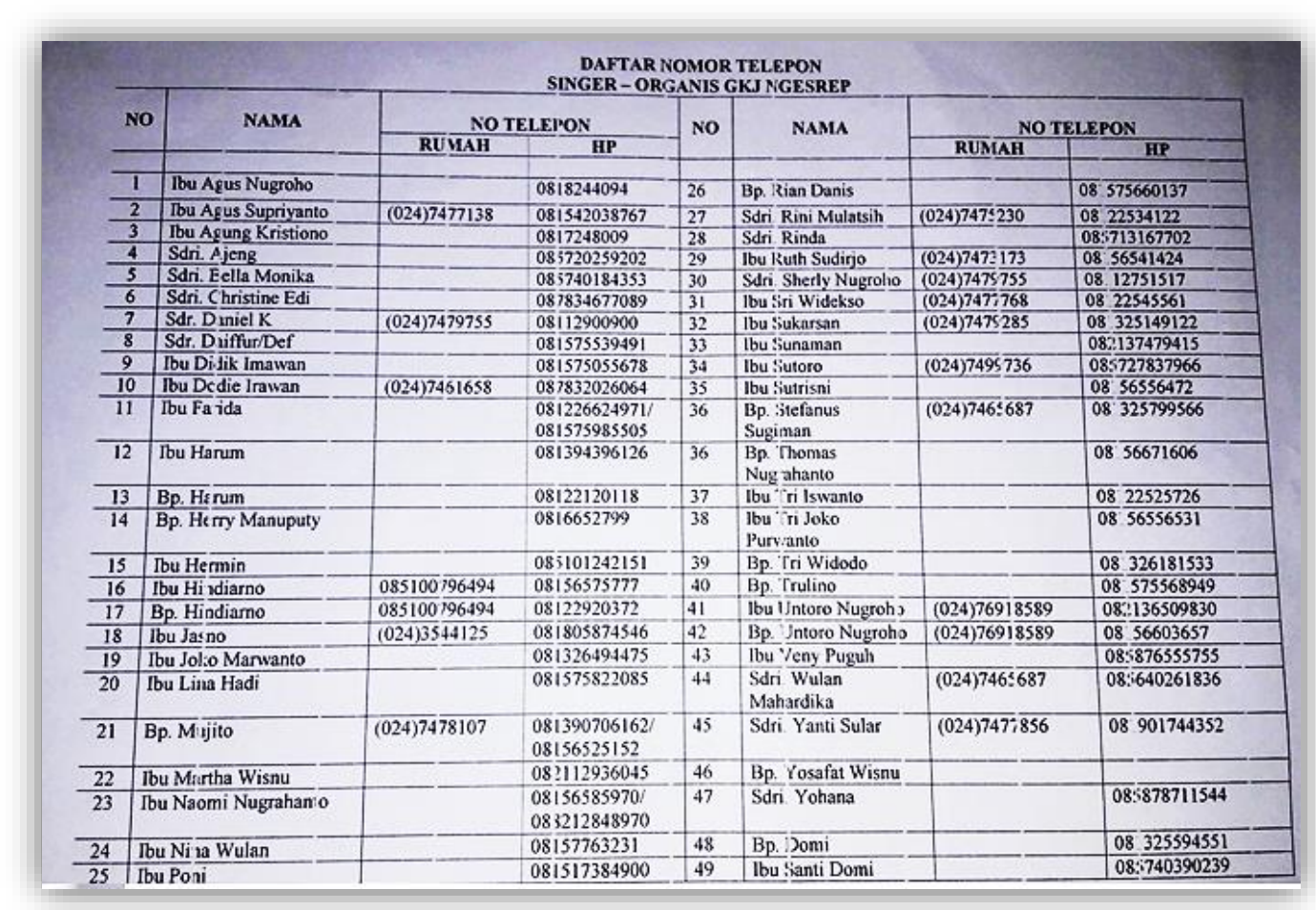

Gambar 16 Daftar Nomor Telefon Pemandu Nyanyian Jemaat dan Organis GKJ Ngesrep

(Sumber: Dokumen Bella Monica Paula, 2017) 


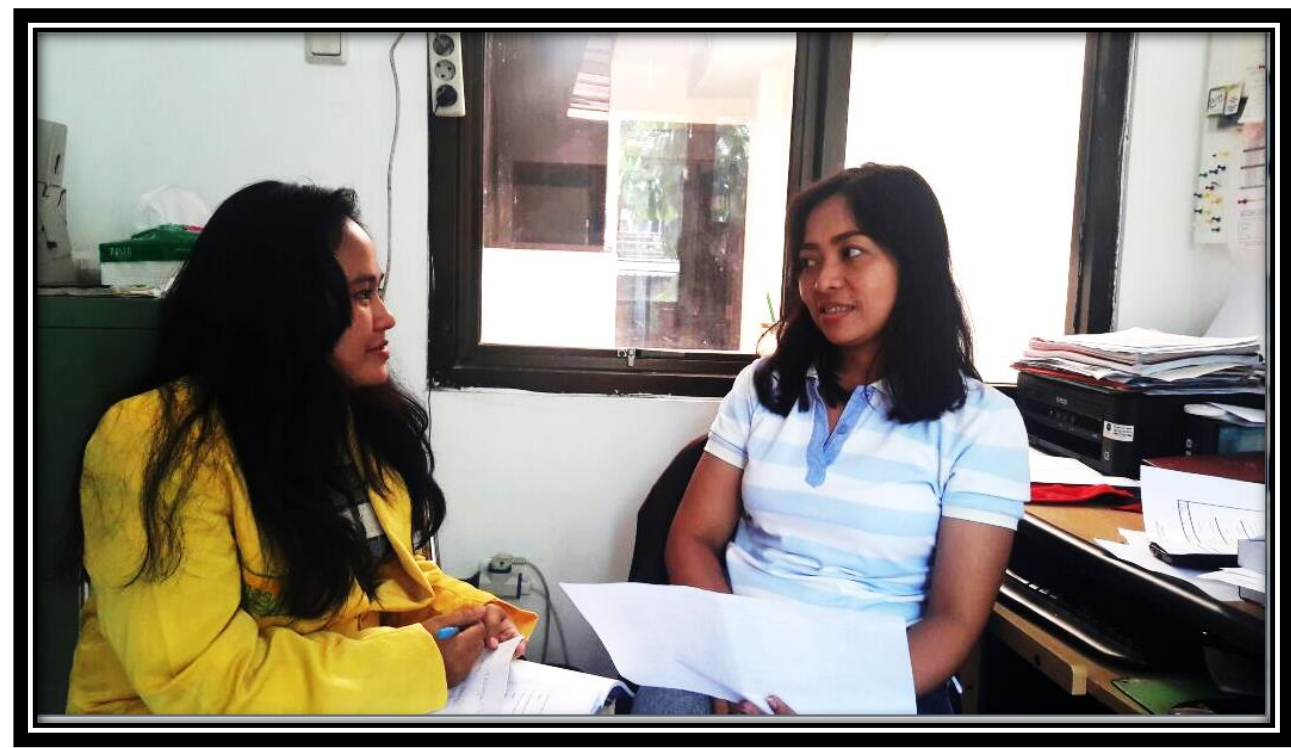

Gambar 17 Bersama Narasumber Salah Satu Anggota Pemandu Nyanyian Jemaat Pada Saat Wawancara

(Sumber: Dokumen Bella Monica Paula, 2017)

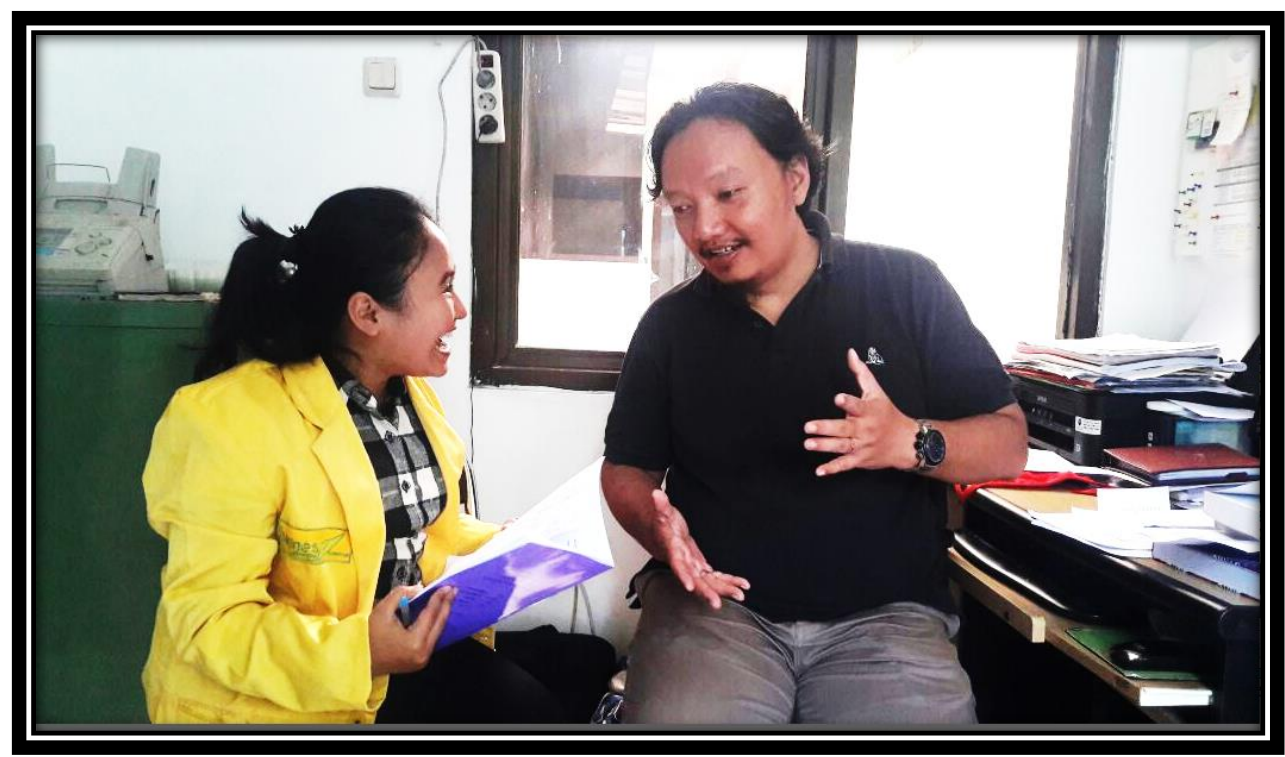

Gambar 18 Bersama Narasumber Bapak Pendeta di GKJ Ngesrep (Sumber: Dokumen Bella Monica Paula, 2017) 


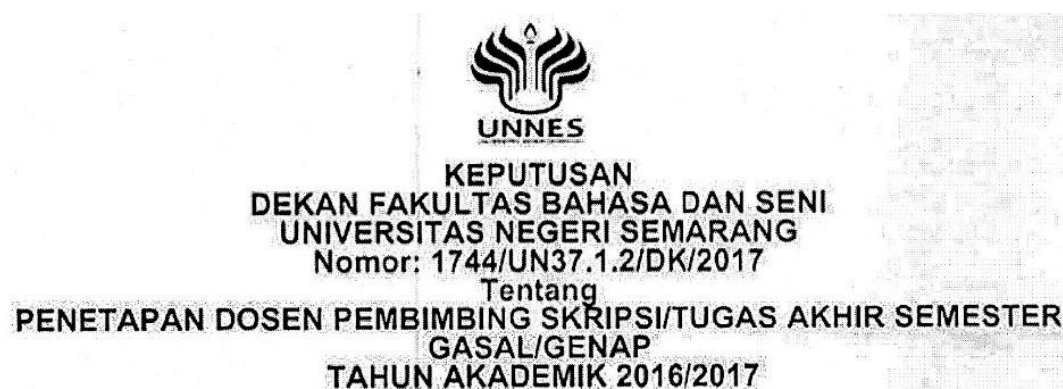

Menimbang : Bahwa untuk memperlancar mahasiswa Jurusan/Prodi Seni Drama, Tari, dan Musik/Pend. Sendratasik Fakultas Bahasa dan Seni membuat Skripsi/Tugas Akhir. maka perlu menetapkan Dosen-dosen Jurusan/Prodi Seni Drama, Tari, dan Musik/Pend. Sendratasik Fakultas Bahasa dan Seni UNNES untuk menjadi pembimbing.

Mengingat : 1. Undang-undang No.20 Tahun 2003 tentang Sistem Pendidikan Nasional (Tambahan Lembaran Negara RI No.4301, penjelasan atas Lembaran Negara RI Tahun 2003. Nomor 78 )

2. Peraturan Rektor No. 21 Tahun 2011 tentang Sistem Informasi Skripsi UNNES

3. SK. Reklor UNNES No. 164/O/2004 lentang Pedoman penyusunan Skripsi/Tugas Akhir Mahasiswa Strata Satu (S1) UNINES:

4. SKRektor UNNES No.162/O/2004 tentang penyelenggaraan Pendidikan UNNES:

Menimbang : Usulan Ketua Jurusan/Prodi Seni Drama. Tari, dan Musik/Pend. Sendratasik Tanggal 15 Maret 2017

Menetapkan

PERTAMA : $\quad$ Menunjuk dan menugaskan kepada:

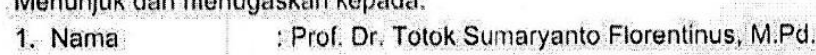

NIP

: 196410271991021001

PangkatGolongan : IV/d

Jabatan Akademik : Guru Besar

Sebagal Pembimbing I

2. Nama :Drs Eko Raharjo. M.Hum

NIP : :196510181992031001

PangkatGolongan : IV/a

Jabatan Akademik : Lektor Kepala

Sebagai Pembimbing II

Untuk membimbing mahasiswa penyusun skripsi/Tugas Akhir :

Nama $\quad$ :BELLA MONICA PAULA

NIM : 2501413147

Jurusan/Prodi Seni Drama, Tari, dan Musik/Pend. Sendratasik

Topik : Peranan Paduan Suara Greja

KEDUA : Keputusan ini mulai berlaku sejak langgal ditetapkan.

Tembusan

1. Pembantu Dekan Bidang Akademik

2. Ketua Jurusan

3. Petinggal

\section{ขIIIIIIIIIIII}

....FM-03.AKD.24/ReV, $00 \ldots . .$.

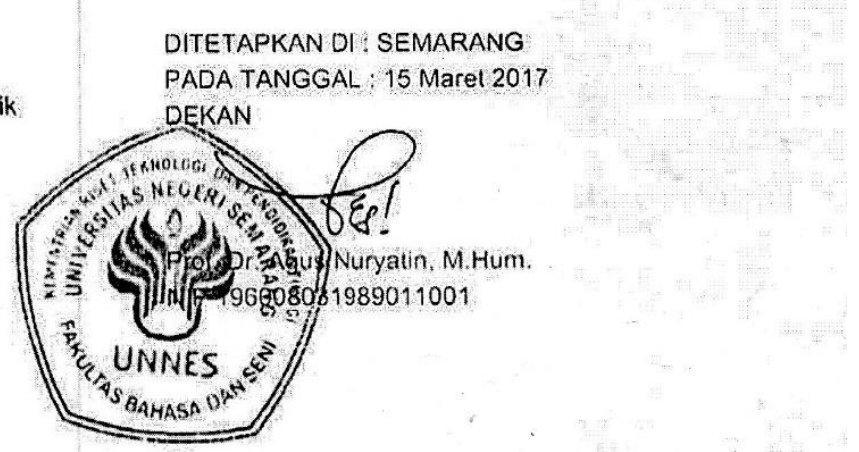

Surat Keputusan Dosen Pembimbing

(Sumber: Dokumen Bella Monica Paula, 2017) 


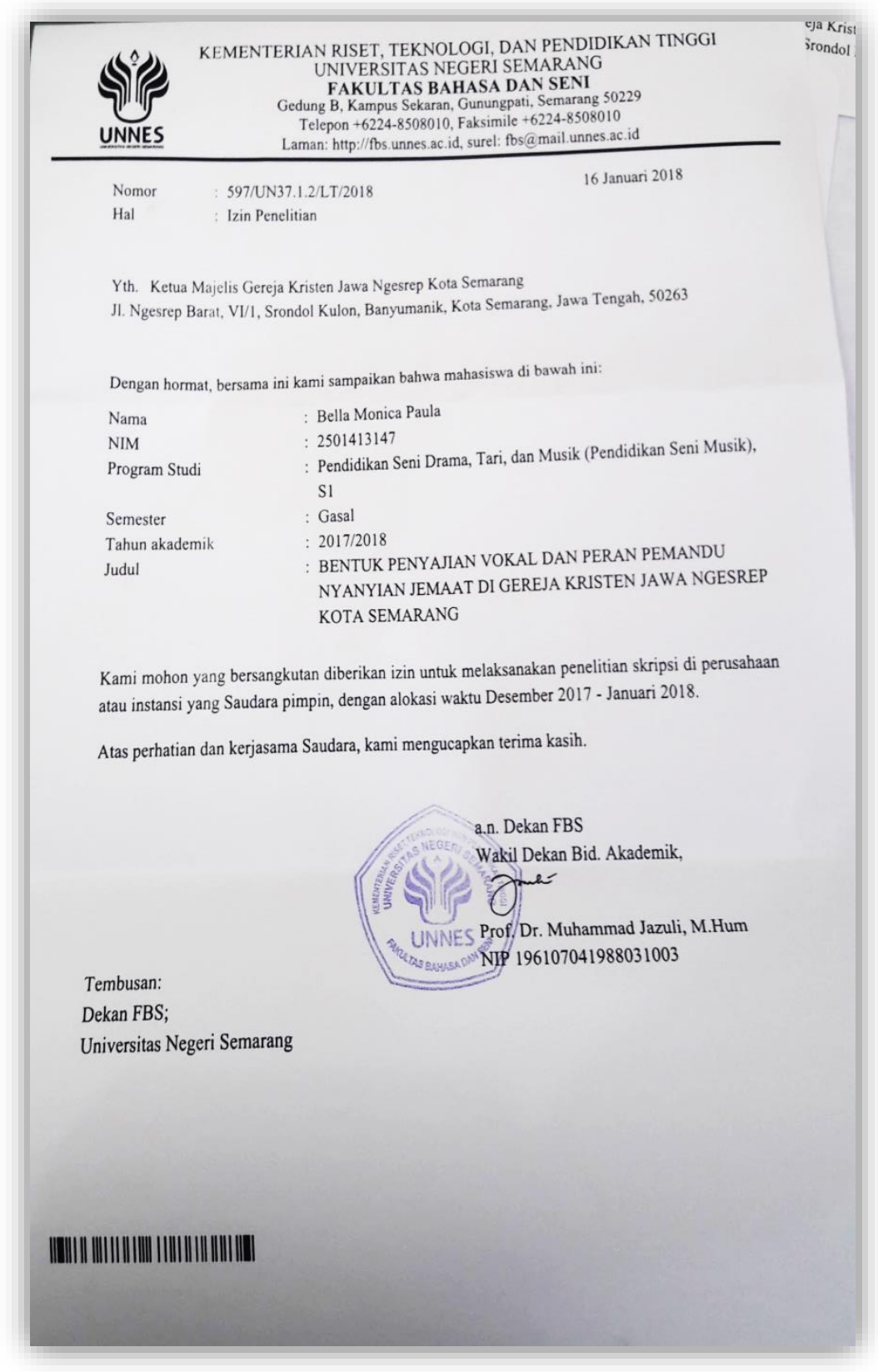

Surat Keterangan Permohonan Ijin Penelitian (Sumber: Dokumen Bella Monica Paula, 2018) 


\section{GEREJA KRISTEN JAWA NGESREP}

(Dalam Persekutuan Gereja - Gereja di Indonesia ) Sekretariat : Jl. Ngesrep Barat VI /1

Semarang - 50263 ( 024.7464231 ) email : gkjngesrep@rocketmail.com No. 19 Th. 1966 - stld 1927 No. 156, 352 dan SK Bimas Kristen No. 126, Th.1988

\footnotetext{
Nomor $\quad: 010 / 504 / G K J . N G P / / 2018$

Lampiran : -

Perihal : Pemberitahuan
}

Kepada Yth.

Dekan Fakultas Bahasa Dan Seni

Universitas Negeri Semarang.

Salam Sejahtera dalam Kasih Tuhan Yesus Kristus.

Menanggapi surat dari Universitas Negeri Semarang Fakultas Bahasa dan Seni nomor 597/UN37.1.2/LT/2018 perihal Izin Penelitian atas diri :

Nama : Bella Monica Paula

NIM : 2501413147

Program Studi $\quad$ : Pendidikan Seni drama, Tari, dan Musik

Semester ( Pendidikan Seni Musik ) S1

Tahun Aka

: Gasal

Judul

: 2017/2018

: BENTUK PENYAJAN VOKAL DAN

PERAN PEMANDU NYANYIAN JEMAAT

DI GEREJA KRISTEN JAWA NGESREP

KOTA SEMARANG

Kami Majelis Gereja setelah melalui rapat majelis pada tgl. 23 Januari 2018 menerima izin penelitian tersebut.

Demikian pemberitahuan kami atas perhatiannya, kami mengucapkan terima kasih.

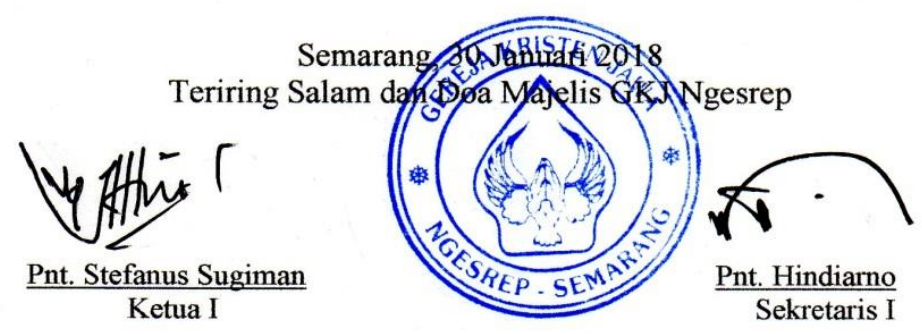

Tembusan :

1. Yth. Bella Monica Paula

2. Arsip

Surat Balasan dari GKJ Ngesrep kepada Dekan Fakultas FBS UNNES

(Sumber: Dokumen Bella Monica Paula, 2018) 


\title{
GERRJA KRISTEN JAWA NGESREP
}

(Dalam Persekutuan Gereja - Gereja di Indonesia)

Sekretariat : Jl. Ngesrep Barat VI /1

Semarang - 50263 (024.7464231) email : gkjngesrep@rocketmail.com No. 19 Th. 1966 - stld 1927 No. 156, 352 dan SK Bimas Kristen No. 126, Th.1988

SURAT KETERANGAN

Nomor : 011/500/GKJ.NGP/II/2018

Dengan ini kami Majelis Gereja Kristen Jawa Ngesrep menerangkan bahwa :
1. Nama
2. NIM
3. Program Studi
4. Semester
5. Tahun Akademik

\author{
: BELLA MONICA PAULA \\ : 2501413147 \\ : Pendidikan Seni Drama,, Tari, dan Musik \\ (Pendidikan Seni Musik), S1 \\ : Gasal \\ : 2017/2018
}

Mahasiswa tersebut di atas, telah melaksanakan Penelitian Bentuk Penyajian Vokal dan Peran Pemandu Nyanyian Jemaat di Gereja Kristen Jawa Ngesrep Kota Semarang, dari bulan Desember 2017 - Januari 2018.

Demikian Informasi Surat Keterangan ini kami buat, untuk dipergunakan sebagaimana mestinya.

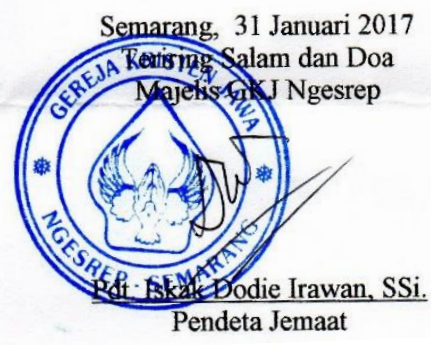

Surat Keterangan Telah Menyelesaikan Penelitian Dari GKJ Ngesrep

(Sumber: Dokumen Bella Monica Paula, 2018) 
BIODATA PRIBADI

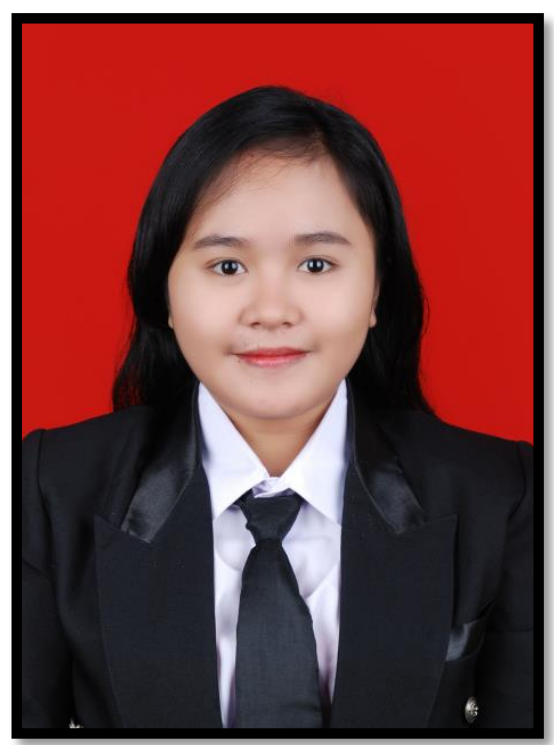

Nama

Alamat

Kode Pos

Nomor Telepon

Email

Jenis Kelamin

Tempat, Tanggal Lahir

Status

Warga Negara

Agama

Orang Tua Ayah

Orang Tua Ibu
: Bella Monica Paula

: J1. Berdikari IV Rt 005 / Rw 007, Srondol

Kulon, Banyumanik, Semarang, Jawa Tengah

: 50263

: 08562698295

: bellamonica765@yahoo.co.id

: Perempuan

: Semarang, 13 Agustus 1995

: Mahasiswa

: Indonesia

: Kristen

: Paulus Purnomo

: Amoempoeni

\section{Riwayat Pendidikan}

\begin{tabular}{|c|c|c|}
\hline Periode & Sekolah/Institusi & Jurusan \\
\hline $2001-2007$ & SD N Srondol 01 A/B Semarang & \\
\hline $2007-2010$ & SMP Maria Mediatrix Semarang & \\
\hline $2010-2013$ & SMA Sedes Sapientiae Semarang & IPS \\
\hline
\end{tabular}

